\title{
ORGANIZATIONAL AND TECHNOLOGICAL MODEL ENGINEERING IN THE CONSTRUCTION INDUSTRY
}

Collective monograph

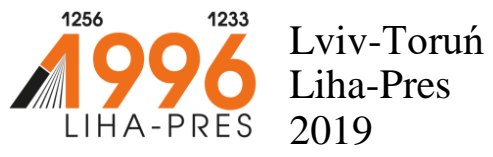




\section{Reviewers:}

dr inż. Michat Sójka, Dean of the Faculty of Mechanical Engineering of Cuiavian University in Wloclawek (Republic of Poland);

dr Zbigniew Brenda, Director of Logistics and Technology Institute of Cuiavian University in Wloclawek (Republic of Poland);

Prof. dr hab. Ryszard Strzelecki, Politechnika Gdańska / Gdansk University of Technology (Republic of Poland).

Organizational and technological model engineering in the construction industry : collective monograph / P. Ye. Hryhorovskyi, S. P. Stetsenko, O. I. Menejljuk, A. S. Molodid, etc. - Lviv-Toruń : Liha-Pres, 2019. - $128 \mathrm{p}$.

ISBN 978-966-397-165-0

Liha-Pres is an international publishing house which belongs to the category "C" according to the classification of Research School for Socio-Economic and Natural Sciences of the Environment (SENSE) [isn: 3943, 1705, 1704, 1703, 1702, 1701; prefixMetCode: 978966397]. Official website www.sense.nl. 


\section{CONTENTS}

BUILDING INFORMATION MODELS AS A BASIS

OF PROCESS AUTOMATION DURING CONSTRUCTION

AND OPERATION OF BUILDINGS AND STRUCTURES

Hryhorovskyi P. Ye.

MULTIPLE CRITERIA MODEL FOR PROVING INVESTMENT

AND CONSTRUCTION PROJECT EFFICIENCY

Stetsenko S. P.

OPTIMIZATION OF CONSTRUCTIVE AND TECHNOLOGICAL

SOLUTIONS OF HIGH-RISE ENGINEERING STRUCTURES

EMERGENCY MEASURES

Menejljuk O. I.

STRENGTHENING OF REINFORCED CONCRETE BEAM

STRUCTURES USING EXTERNAL REINFORCEMENT.

EFFICIENCY RESEARCH

Molodid A. S

MAIN CONTRADICTION OF RELATIONS AT CONSUMER MARKETS AND WAYS OF ITS OVERCOMING

Khyzhniak V. O.

APPLIED SCIENTIFIC TOOLS OF IMPROVING

THE EFFICIENCY OF ECONOMIC ENVIRONMENT

OF CONSTRUCTION ENTERPRISES OPERATION

IN THE PROJECT DEVELOPMENT SYSTEM

Ryzhakova G. M. 


\section{BUILDING INFORMATION MODELS AS A BASIS OF PROCESS AUTOMATION DURING CONSTRUCTION AND OPERATION OF BUILDINGS AND STRUCTURES}

\section{Hryhorovskyi P. Ye.}

\section{INTRODUCTION}

Methods of engineering, process mechanization and automation, project organization and management are interrelated and geared at a common objective - to shorten periods and ensure quality of construction, to prolong life cycles of construction projects by applying engineering and technical solutions on automatic control of processes with the use of construction information models and technologies, data obtained by instrumental measurements at all life cycle stages. Designing of integrated models and methods of automated systems for diagnostics of building operating conditions is an initial stage of development of a complex automated system that ensures serviceability of buildings. Components for instrumental measurements and program processing of data are integral parts of the automated system. Therefore measurements and software are the basic elements for automation of engineering processes at all stages of life cycle of buildings.

\section{Procedure of selection of information technologies for estimation of serviceability of buildings during their life cycles}

The building life cycle is subdivided into stages of survey, design work, preparation work, earthwork, construction of above-ground structures, operation and period of deterioration. The last stage may finalize the life cycle by means of liquidation or starting a new life cycle under the condition of reconstruction, overhaul or technical re-equipment that is by renewal of building operating conditions ${ }^{1}$. The life cycle interval is an important integral quality characteristic of building construction and operation. It depends on timely detection, correction and prediction of development of defects and damages which are impossible without acquisition and program processing of objective data on serviceability of buildings. Data

\footnotetext{
${ }^{1}$ Havryliak A.I. Operation, reconstruction and modernization of buildings / A. I. Havryliak, I. B. Bazarnyk, R. I. Kinash et al. - L'viv: Publisher National University «L'vivska politekhnika», 2006. -537 p. (in Ukrainian).
} 
objectiveness is ensured by instrumental methods of measurements. Generally, the up-to-date technologies and technical facilities comply with technological, regulatory and project requirements for quality during construction and operation of buildings.

Methods of execution of work, interrelations and interference of measurement and construction work affect efficiency of technological solutions, technical and economic indices of work performance, quality of work and duration of life cycles of projects. At the stage of construction the list and scope of measurements and work quality checks depend on applied technologies and materials, architectural and structural designs, conditions of construction. Jobs on construction of buildings with identical space and planning parameters but different structural or organizational and technological solutions have various scope and sequences of construction and measuring operations and this affects technical and economic indices of processes. Therefore, the technical and economic indices of measuring jobs at the construction and operation stages with identical scopes of jobs depend on organizational and technological as well as architectural and structural solutions.

Buildings differ in levels of complexity and uncertainty of their operating conditions, the number of factors that affect the processes of construction and operation, result in their deterioration, occurrence of deformations, defects and damages, therefore the required volume of data, methods of their processing, information models, methods and measures for execution of jobs directed on prolongation of life cycles of buildings depend on their structural features and technologies used for their construction and operation. Information about quality of a new construction project, defects and damages of facilities under operation shall be presented as a hard copy or in electronic format, as-built surveys, quality control data, defect charts or lists, inspection reports etc. Determination of interdependence of defects and causes of their occurrence, prediction of effects of these defects on future operating conditions of facilities is an important complex task that requires detailed studies with the use of up-to-day methods of information simulation.

Works of leading scientists show that the process of determination of parameters of buildings, structures or developed areas is under impact of destabilizing factors on technical and economic indices and accompanied by a set of specific features. In general these aspects are characterized by as follows:

- increased demands for growth in volumes and efficiency of construction of civil and industrial facilities, reconstruction and overhaul of facilities under operation; 
- shortened periods of construction and increased periods of operation of facilities due to application of new technologies, designs, equipment and materials;

- increased social role of safety and decreased levels of risks of facility wrecks due to ensured quality and reliability of construction and operation processes;

- complex studies of properties of buildings, simulation of their behavior under operating and dense development conditions before construction is started;

- necessity to develop systems of engineering solutions on the basis of the methodological support of engineering design process;

- intensification of engineering studies, raising the level of detailed design engineering with accounting for distinctive features when efficient measuring and data processing procedures are applied;

- improved quality and complexity of building operations and processes, skill levels of technicians;

- increased scopes and importance of complex projects.

Working hypothesis. If we take into account the specific features and the impact of destabilizing factors on technical and economic indices of the process of instrumental determination of parameters of buildings with the aim to ensure their serviceability, it will allow us to optimize engineering processes at all stages of their life cycle. Thus, there is an opportunity to shorten building construction periods and prolong periods of building operation by implementing effective organizational and technological solutions that have been developed on the basis of data which have been obtained reliably and in proper time with the use of methods of instrumental measurements and which are necessary and sufficient for ensuring the serviceability of buildings and structures at all stages of their life cycles.

The scientific problem consists in a necessity of theoretical justification of a system of conceptual, theoretical and methodological principles of prolongation of the service life and optimization of engineering, technical and economic indices of construction and operation of buildings on the basis of application of efficient methods of instrumental measurements for collecting in proper time, processing and using reliable data that are necessary and sufficient for ensuring the serviceability of buildings at all stages of their life cycles. The application of information technologies will be favorable for solving this problem.

Selection of information technologies is an important component of a systemic approach to the issues of surveying, designing, construction, examination and diagnostics of building operating conditions. Such an approach is a necessity because the processes of determination, processing and application of data on parameter values of buildings, structures and 
developed areas require the use of developed interactive means of cooperation and support from experts with various levels of training in generation of information systems and models with the use of multiwindow models or screens, menu structures, dialog sequences etc. The data are collected from various sources and studied with various levels of detailing. The system capacity may be increased by applying an open architecture, and allowing the scaling of the system with connected both internal and external facilities, and arranging the modularity of applied programs, and supporting the flexibility of the required configuration of the system, and ensuring the use of open standards. Figures 1 and 2 show schemes of information technologies for an automated system and an algorithm of management information system for technical diagnostics of buildings.

\begin{tabular}{|c|c|c|}
\hline $\begin{array}{c}\text { Establishment of general } \\
\text { principles for generating a } \\
\text { diagnostics system of building } \\
\text { operating conditions at all stages } \\
\text { of life cycle }\end{array}$ & $\begin{array}{c}\text { Substantiation of efficiency of } \\
\text { technologies and means of } \\
\text { instrumental determination of } \\
\text { parameters of buildings, structures } \\
\text { and developed areas }\end{array}$ & $\begin{array}{l}\text { Selection of organizational and } \\
\text { technological indices for } \\
\text { calculation of efficiency of } \\
\text { measuring systems and } \\
\text { technology of their application }\end{array}$ \\
\hline $\begin{array}{c}\text { Establishment of necessary scopes } \\
\text { of instrumental examinations } \\
\text { during operation of buildings and } \\
\text { structures }\end{array}$ & $\begin{array}{l}\text { Determination of duration and } \\
\text { periodicity of instrumental } \\
\text { examinations as a component of } \\
\text { expenditures on operation of } \\
\text { measuring systems }\end{array}$ & $\begin{array}{l}\text { Effects of organizational and } \\
\text { technological indices on } \\
\text { efficiency of measuring systems } \\
\text { and technology of their } \\
\text { application }\end{array}$ \\
\hline \begin{tabular}{|c|} 
Substantiation of time \\
expenditures for execution of \\
measuring activities at all stages \\
of building life cycles
\end{tabular} & ANALYSIS OI & $\begin{array}{l}\text { INFORMATION } \\
\text { ES }\end{array}$ \\
\hline \begin{tabular}{|c|} 
Models and methods of creation \\
of a knowledge base for \\
diagnostics of building operating \\
conditions on the basis of the \\
theorv of furzzy sets
\end{tabular} & $\begin{array}{l}\text { Experimental studies and } \\
\text { implementation of neural } \\
\text { networks of the diagnostics } \\
\text { system of building operating } \\
\text { conditions } \\
\end{array}$ & $\begin{array}{c}\text { Estimation procedure for } \\
\text { predictions of solutions made by } \\
\text { the diagnostics system of building } \\
\text { operating conditions }\end{array}$ \\
\hline
\end{tabular}

Fig. 1. Block scheme of up-to-date information technologies for an automated system of diagnostics of building operating conditions

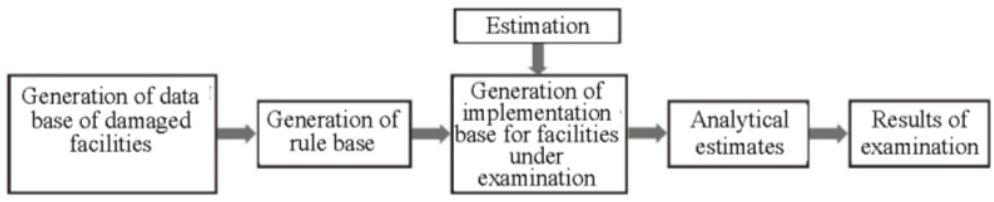

Fig. 2. Functional scheme of a management information systemfor diagnostics of building operating conditions 
The principle of designing of facilities with the use of their information models provides for the modelling process with preparation and complex processing of architectural and design, technological, economic and other data on a facility with all interrelations and dependencies in which a building and all related things are considered as a single facility ${ }^{2,3}$. This conception was named 'Building Information Modelling' or shortly BIM.

The main advantages of BIM are as follows: the whole project life cycle is simulated, from a conception until operation and demolition; in designing the facilities that possess necessary information about geometrical and technical characteristics of structures, elements and a building as a whole are used; the use of such facilities accelerates the design process and minimizes errors; sections generated by various systems of computer-aided design are used jointly and the design process is performed in 3D space with an allowance for time; an open standard of data exchange. Implementation of BIM is a strategic issue for the construction industry and its solving is an objective necessity ${ }^{4,5,6,7,8}$.

The building information model is a digital representation of systematic information about a facility that is used at all stages of life-cycle ${ }^{9,10}$. Application of an information model facilitates operations with a facility and offers significant benefits as compared with the traditional design methods $3,8,11,12,13,14,15,16,17,18,19,20,21,22,23$. Such a model allows unification,

2 Astaf'eva N.S., Kibireva Yu.A, Vasil'eva I.L. Advantages of application and difficulties of implementation of the building information modelling // Construction of unique buildings and structures. ISSN 2304-6295. 8 (59). 2017. P. 41-62 (in Russian).

3 Talapov V.V. Building information modelling - modern conception // CADmaster. 2010.No. P.114-121 (in Russian).

${ }^{4}$ Chikovskaia I.I. Implementation of BIM - experience, scenarios, mistakes, conclusions // SAPR and Graphics. 2013. No. 8. P. 18-22 (in Russian).

5 Krinitskii E.V., Yakubson V.M., Vatin N.I. Building information modelling (BIM) // Engineering and building journal 2010. No. 2(12). P. 16-18 (in Russian).

${ }^{6}$ Kozlov I.M. Estimation of economic efficiency of implementation of the building information modelling //AMIT. 2010. No. 1(10). P. 1-9 (in Russian).

${ }^{7}$ Demenev A.V., Artamanov A.C. Information modelling in the process of operation of buildings and structures // Sociology of science. 2015. No. 3. P. 1-9 (in Russian).

8 Talapov V.V. Technology of BIM. Essence and peculiarities of implementation of the building information modelling. M.:Publisher DMK Press, 2015. $410 \mathrm{p}$ (in Russian).

9 Vorob'ev A., Danilova L., Ignatov B., Ryndin A., Tuchkov A., Utkin A., Fertman I., Scheglov D. Scenario and mechanisms for developing a unified information space // CADmaster. 2010. No. 5. P. 48-51 (in Russian).

${ }^{10}$ Zamataev D.V. Study of approaches to virtual modelling // Mining information-analytical bulletin (scientific and engineering journal). 2014. No. 9. P. 312-316 (in Russian).

${ }^{11}$ Melikhov N.S., Kostiuchenko A.Yu., Yaschenko A.A., Narezhnaia T.K. Advantages of $\mathrm{BIM}$ in performing expert examination of design documentation // International scientific and research journal. 2016. No. 5-3. P. 143-145 (in Russian).

${ }^{12}$ Lushnikov A.S. Problems and advantages of implementation of BIM technologies in construction companies // Bulletin of civil engineers. 2015. No. 6. P. 252-256 (in Russian). 
calculation and coordination of components and systems developed by various specialists and institutions, checking their viability, serviceability and preventing internal mismatches and emergencies ${ }^{24}$.

Numerical data are used during a life cycle of facility for making project decisions, updating project documentation, predicting serviceability, drawing estimates and scheduling, ordering materials and equipment, managing construction work, operation, utilities commercial activities, reconstruction or repair work, if necessary, demolition and utilization of the facility, other tasks related to the facility ${ }^{6-12,25,26}$.

${ }^{13}$ Seliutina L.G., Timofeev S.V. Analysis of foreign experience of development and application of information modelling technologies in construction // Problems of construction economics and management under conditions of environmentally sensitive development. Tomsk: Publisher: Tomsk State Architectural and Construction University, 2015. P. 324-329 (in Russian).

${ }^{14}$ Perepelitsa F.A., Petukhova E.A. BIM standards in the world practice // Electronic scientific journal. 2015. No. 1(1). P. 561-566 (in Russian).

${ }^{15}$ Manukhina L.A., Yaschenko A.A. Integration of organizational and technological solutions with BIM // Innovation technologies in science and education. 2015. No. 2(2). P. 246-249 (in Russian).

${ }^{16}$ Talapov V.V. Principles of BIM: introduction into the building information modelling. M.: Publishers DMK Press, 2011. 392 p (in Russian).

${ }^{17}$ Ignatova E.V. Solving of problems on the basis of a building information model // Bulletin of MGSU. 2012. No. 9. P. 241-246 (in Russian).

${ }^{18}$ Talapov V.V. BIM in Russia: new building of Mariinskii Theatre [Electronic resource] URL: http://isicad.ru/ru/articles.php?article_num=14257 (date of visiting: 20.02.2016) (in Russian).

${ }^{19}$ Mitrofanova N.O., Chernov A.V., Berezina E.V. Possible applications of BIM technologies // Interexpo Geo-Siberia. 2016. No. 2. P. 177-182 (in Russian).

${ }^{20}$ Grakhov V.P., Mokhnachev S.A., Manokhin P.E., Ishtriakov A.Kh. Organizational improvements of design work by implementation of building information modelling technologies // Modern problems of science and education. 2015. No. 1-1. P. 615 (in Russian).

${ }^{21}$ El'sheikh A.M. Information modelling in integrated computer-aided designing and scheduling in construction [Place of thesis defence: Moscow State Building University]: abstract of thesis for a candidate degree in technical sciences: 05.13.12, 05.02.22 / A.M. El'sheikh. M., 2015. 21 p. (in Russian).

${ }^{22}$ Pailevanian B.S. Rising the level of environmental safety and energy consumption efficiency of buildings on the basis of intellectual technologies [Place of thesis defence: Moscow State Building University]: abstract of thesis for a candidate degree in technical sciences: 03.00.16 / B.S. Pailevanian. M., 2009. 23 p. (in Russian).

${ }^{23}$ Volynskov V.E. Information-technological methods of designing in architectural forming [Place of thesis defence: Moscow State Building University]: abstract of thesis for a candidate degree in architecture: 05.23.20 / V.E. Volynskov. - M., 2012. - 25 p. (in Russian).

${ }^{24}$ Alekseev S.A., Tyshkevich A.V., Alekseeva A.S., Chernykhovskii B.A. Urgency of implementation of the building information modelling in construction // Scientific discussion: issues of technical sciences. 2016. No. 1(31). P. 7-11 (in Russian).

${ }^{25}$ Talapov V.V. BIM is a basis // CADmaster. 2010. No. 4. P. 13 (in Russian).

${ }^{26}$ Morozov V.S., Ort A.I. Designing: from vocation to self-education // St. Petersburg: Construction, Technologies, Organization. 2014. No. P. 14-15 (in Russian). 
Unlike the traditional computer-aided design systems that generate geometrical images the result of information modelling is a digital model that includes as a facility itself as a process of its construction, operation and utilization $^{26,27,28,29,30,31,32,33,34,35}$. The US National Building Information Model Standard Project Committee has the following definition ${ }^{36,37}$ : 'BIM is a digital representation of physical and functional characteristics of a facility. A BIM is a shared knowledge resource for information during its life-cycle defined as existing from earliest conception to demolition, $38,39,40,41,42,43,44,45,46,47$.

${ }^{27}$ Malinovskii M.E. Information modelling technologies in design institutions // Anthology of world science. 2016. No. 4-1(7). P. 121-122 (in Russian).

${ }^{28}$ Panteleev A.S. Substantiation of effects exerted by investments on economic growth of enterprises in the construction industry of the North-West Federal Region of the RF [Place of thesis defence: Peter the Great SPbPU]: graduate thesis: 38.04.01: defended on 13.09.16: approved on 13.09.16 / Panteleev Alexander Sergeevich; Peter the Great SPbPU - SPb, 2016. 113 p. (in Russian).

${ }^{29}$ Postnov K.V. Application of BIM technologies for the management processes in design institutions // Scientific review. 2015. No. 18. P. 367-371 (in Russian).

${ }^{30}$ Bachurina S.S., Golosova T.S. Investment component in BIM implementation projects // Bulletin of MGSU. 2016. No. 2. P. 126-134 (in Russian).

${ }^{31}$ Del'tsova T.D., Afanas'eva T.V., Slepkova T.I. Efficiency of application of BIM technologies during reconstruction of facilities // Economy and Business. 2015. No. 6-3. P. 741-744 (in Russian).

${ }^{32}$ Rumiantseva E.V., Manukhina L.A. BIM technologies: an approach to designing a construction facility as a single whole // Modern science: urgent problems and ways of their solving. 2015. No. 5(18). P. 33-36 (in Russian).

${ }^{33}$ Chetverik N.P. Step-by-step implementation of information modelling technologies (BIM) in the construction sphere // Bulletin 2014 No. 12(191) P.44-47 (in Russian).

${ }^{34}$ Chernykh M.A., Yakushev N.M. BIM technology and program products on its basis in Russia // Bulletin. 2014. No. 1(61). P. 119-121 (in Russian).

${ }^{35}$ Talapov V.V. What does affect the implementation of BIM in Russia // SAPR and Graphics. 2010. No. 11(169). P. 12-16 (in Russian).

${ }^{36}$ Chikovskaia I.I., Novozhenina I.N. Trends in development of BIM in Russia. SAPR and Graphics. 2014. No. 8(214). P. 8-11 (in Russian).

${ }^{37}$ Eltyshev Yu.V., Kirillov A.I., Talapov V.V. BIM and metal structures: some examples // CAD-master. 2010. No. 4. P. 109-110 (in Russian).

${ }^{38}$ Baiburin A.Kh. Comprehensive estimation of quality of building operations / A.Kh. Baiburin // Bulletin of URGU. - 2005. - No. 13. - P. 68-70 (in Russian).

${ }^{39}$ Halins'kyi O. Arrangement of building production [Text]: DBN A.3.1-5:2016. [enforced from 2016-08-01] / O. Halins'kyi, P. Hryhorovskiy, A. Kotliarenko et al. - K.: Minregionbud of Ukraine, 2016. - 51 p. - (State building code of Ukraine) (in Ukrainian).

${ }^{40}$ Hryhorovskiy P.Ye. Method for determination of a compactness factor around a new construction facility / P.Ye. Hryhorovskiy, M.I. Nadtochii // Development management for complex systems: collection of scientific papers - K.: KNUBA. -2013 . - No. 16. - P. 181-183 (in Ukrainian).

${ }^{41}$ Hryhorovskiy P.Ye. Application of operating condition monitoring for buildings and structures for studying geodynamic and man-caused processes of their construction and operation / P.Ye. Hryhorovskiy, I.V. Trevoho, N.P. Chukanova // Geoinformation environmental monitoring: GNSS and GIS technologies: Proceedings of XXVIII International 
Diagnostics of building operation conditions may be performed with the use of information technologies: expert systems, fuzzy systems, fuzzy neural networks or hybrid networks, information storage and retrieval systems, intelligence decision-support systems and others shown in Fig. 3. Table 1 shows comparative characteristics of information technique methods.

Expert systems may be used for generation of expert models and models for diagnostics of building operating conditions, in studying information and expert systems, for generation of knowledge bases and fuzzy rules of studies in implementing management systems for examination and diagnostics of building operating conditions, for studies of logic chains in diagnostics of building operating conditions.

Expert systems are implemented and used in such program complexes as: Mycin, Neomycin, Emycin, Prospector, Diagen, Genrost, Internist-I, Sphinx, Pheo-attending (the medical expert systems), Exsys (designed for generation of expert systems of classification type), 1st-Class, Personal Consultant Plus, STES (software tools of expert systems), GURU (integrated environment for development of expert systems).

Scientific and Engineering Symposium. 10-15 September 2013. - Alushta, 2013. - P. 136-143 (in Ukrainian).

${ }^{42}$ Hryhorovskiy P.Ye. Selection of optimal methods for monitoring of building structures operating conditions with the use of utility functions / P.Ye. Hryhorovskiy, N.P. Chukanova // New technologies in construction: collection of scientific and engineering papers - K.: Publishers «Lira-K», 2014. - Issue. 27-28. - P. 21-24 (in Ukrainian).

${ }^{43}$ Hryhorovskiy P.Ye. Details of calculations of costs of labor for conducting survey operations in construction / P.Ye. Hryhorovskiy, N.P. Chukanova // Modern achievements of the land-surveying science and production: collection of scientific papers of the West Geodetic Society UTGK. - Lviv: Publishers Lviv Polytechnika, 2014. - Issue 1(27). - P. 148-151 (in Ukrainian).

${ }^{44}$ Hryhorovskiy P.Ye. Monitoring of building structures inclination with the use of an electronic plumb rule / P.Ye. Hryhorovskiy, Yu.V. Deineka, V.O. Kosolap // Building production: collection of scientific and technical papers - K.: TsP «Comprint», 2009. Issue. 50. - P. 8-10 (in Ukrainian).

${ }^{45}$ Hryhorovskiy P.Ye. Normative provisions for determination of estimated costs and labor intensities of construction work under restricted conditions / P.Ye. Hryhorovskiy, M.I. Nadtochii // Options for improvement of construction efficiency under conditions of formation of market relations: collection of scientific papers - K.: KNUBA - 2010. - No. 22. P. 87-93 (in Ukrainian).

${ }^{46}$ Hryhorovskiy P.Ye. Experience of conducting geodetic monitoring during reconstruction of the National Sports Complex 'Olimpiiskyi' / P.Ye. Hryhorovskiy, Yu.V. Deineka // New technologies in construction: collection of scientific and technical papers - K.: Publishers «LiraK», 2010. - Issue 19. - P. 18-20 (in Ukrainian).

${ }^{47}$ Hryhorovskiy P.Ye. Composition of knowledge base for an information expert system for selection of methods to be used during performance of survey operations in construction / P.Ye. Hryhorovskiy, Yu.V. Deineka, V.O. Kosolap // New technologies in construction: collection of scientific and technical papers - K.: Publishers «Lira-K», 2011. - Issue 21. P. 48-51 (in Ukrainian). 


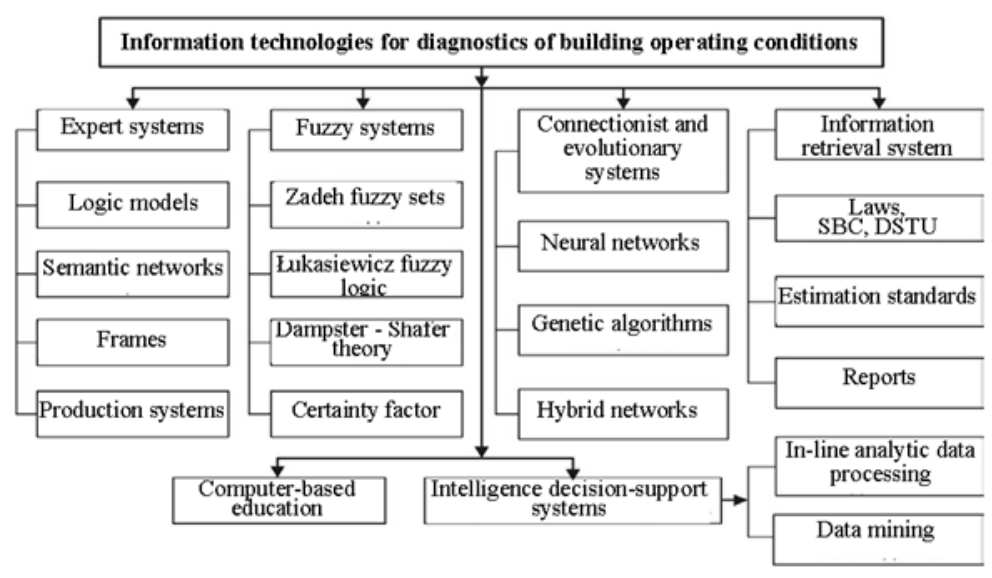

\section{Fig. 3. Block-scheme of building status information technologies}

Fuzzy systems may be used for solving information technology tasks such as diagnostics of building operating conditions, development of a knowledge bas for facilities, development of a fuzzy conclusion system, research into diagnostic models for building conditions on the basis of fuzzy logics techniques.

Fuzzy systems are implemented and used in such systems as $M O \check{S} / M I S$ (Mestská a Obecná Štatistika/Mestský Informačný Systém (Urban and municipal statistics / urban information system). They are used as an initial base for development a knowledge-based system. The «Systema - $P$ » system is a module of combined navigation satellite receiver (MCNR) that is designed for application in corporate integrated navigation and communication management and control systems. $C A D$ is a technique that combines a single complex for solving computer-aided designing tasks. $C A M$ is a process management system.

Fuzzy neural networks or hybrid networks combine benefits of neural networks and fuzzy inference systems. They provide for obtaining information about examinations of building operating conditions in the form of predictions, make it possible to use a training principle on the basis of available information for construction of neural networks, to develop system models in the form of fuzzy rules that are characterized by visibility and simple content interpretation. The fuzzy neural networks or hybrid networks are applied in the following systems: ANFIS (adaptive network-based fuzzy inference system) and RAISON (an integrated system based on knowledge, it comprises a neural network, data base, geoinformation system, cartographic analyzer, graphic and software language components). 


\section{Comparative characterization of methods of information technologies}

\begin{tabular}{|c|c|c|}
\hline Method & Benefits & Shortcomings \\
\hline $\begin{array}{c}\text { Expert } \\
\text { systems }\end{array}$ & $\begin{array}{l}\text { Development of expert models for examination } \\
\text { and diagnostics of building operating conditions; } \\
\text { research into information and expert systems; } \\
\text { development a knowledge base and fuzzy rules; } \\
\text { research into chains of logic conclusions for } \\
\text { diagnostics of technical status. }\end{array}$ & $\begin{array}{l}\text { Complexity of representation of } \\
\text { expert's profound knowledge on } \\
\text { examination and diagnostics of } \\
\text { building operating conditions; } \\
\text { complexity of arrangement of } \\
\text { training on the basis of the } \\
\text { expert's experience. }\end{array}$ \\
\hline $\begin{array}{l}\text { Fuzzy } \\
\text { systems }\end{array}$ & $\begin{array}{l}\text { Development of a knowledge base for buildings, } \\
\text { development of a system of fuzzy deduction; } \\
\text { research and implementation of diagnostic } \\
\text { models for building operating conditions on the } \\
\text { basis of fuzzy logic tools. }\end{array}$ & $\begin{array}{l}\text { Subjectivity of examinations } \\
\text { and diagnostics of building } \\
\text { operating conditions; it doesn't } \\
\text { allow training. }\end{array}$ \\
\hline $\begin{array}{c}\text { Fuzzy } \\
\text { neural } \\
\text { networks or } \\
\text { hybrid } \\
\text { networks }\end{array}$ & $\begin{array}{l}\text { Possibility of obtaining information about } \\
\text { examination of buildings in the form of } \\
\text { prognosis; construction of neural networks for } \\
\text { examinations and diagnostics is performed by } \\
\text { their training on the basis of available and } \\
\text { accessible information; they allow development } \\
\text { and representation of system models as rules of } \\
\text { fuzzy productions that offer visualization and } \\
\text { simple interpretation of content. }\end{array}$ & $\begin{array}{l}\text { Representation of knowledge } \\
\text { about examinations and } \\
\text { diagnostics of building } \\
\text { operating conditions is obtained } \\
\text { in the special form that may } \\
\text { significantly differ from } \\
\text { possible content interpretation } \\
\text { of existing interrelations and } \\
\text { relations. }\end{array}$ \\
\hline $\begin{array}{l}\text { Genetic } \\
\text { algorithms }\end{array}$ & $\begin{array}{l}\text { In searching of an optimum a number of points } \\
\text { are checked simultaneously instead of passing } \\
\text { from one point to another and in this way local } \\
\text { optimums are excluded; no additional } \\
\text { information is required and this increases a } \\
\text { speed of algorithm operation; deterministic and } \\
\text { probable rules are used. }\end{array}$ & $\begin{array}{l}\text { Numeric not symbolic data are } \\
\text { used. }\end{array}$ \\
\hline $\begin{array}{l}\text { Information } \\
\text { storage and } \\
\text { retrieval } \\
\text { systems }\end{array}$ & $\begin{array}{l}\text { Availability of laws, normative documents, } \\
\text { estimation standards, state building code (SBD), } \\
\text { standards DSTU and others. }\end{array}$ & $\begin{array}{l}\text { Lack of an information system } \\
\text { that will ensure data processing } \\
\text { and selection of an optimal } \\
\text { technology subject to availability } \\
\text { of corresponding data bases in the } \\
\text { automatic mode. }\end{array}$ \\
\hline $\begin{array}{l}\text { Computer- } \\
\text { based } \\
\text { education }\end{array}$ & $\begin{array}{l}\text { Education tasks are solved on the basis either a } \\
\text { labyrinth model that provides for either a search } \\
\text { of direction of motion among the labyrinth of } \\
\text { possible variants or establishment of associative } \\
\text { links in neural-like structures }\end{array}$ & $\begin{array}{l}\text { Problems of generalization, } \\
\text { accumulation of skills in solving } \\
\text { tasks and application of such } \\
\text { problems in solving new tasks }\end{array}$ \\
\hline $\begin{array}{l}\text { Intelligence } \\
\text { decision- } \\
\text { support } \\
\text { systems }\end{array}$ & $\begin{array}{l}\text { The use of capabilities of building examination } \\
\text { information systems; contemporary data bases } \\
\text { comprise a number of technologies that improve } \\
\text { intellectual capabilities; intelligence information } \\
\text { systems for examination of facilities combine } \\
\text { the capabilities of DBMSs that are the basis of } \\
\text { information systems and as a result of this the } \\
\text { storage of information about examinations is } \\
\text { combined with data processing and preparation } \\
\text { for using in making decisions }\end{array}$ & $\begin{array}{l}\text { Complexity of representation of } \\
\text { various types of information }\end{array}$ \\
\hline
\end{tabular}

Genetic algorithms are applied for searching an optimum among some points simultaneously instead of using a point-by-point procedure. Such an 
approach excludes local optimums and the necessity of any additional information, increases operation of the algorithm. At that deterministic and probabilistic rules are used.

An information storage and retrieval system comprises legislative acts, normative documents, standards, registers of accident-prone facilities. The following may be considered as the information technology issues: construction and development of software, its adaptation for permanently evolving needs of users, fast and easy collection and review of information, keeping the status of actuality of the information, development and submission analytical summaries to users and others.

The intelligence decision-support system is a system for examination of operating conditions of construction facilities that combines capabilities of the data base management system, the basis of information systems. As a result the storage of data of examinations is combined with the operations of data processing and preparation to be used in decision making. The task of analysis is a search of hidden patterns, dependencies and interrelations which are useful in making decisions at various levels of the hierarchy. The intelligence decision-support systems are implemented and used in the following systems: OLAP (Discovery System and OLAP Affinity System) is designed for the intelligence analysis of many-dimensional aggregated data; the intelligence system $C A A P P$ is designed for supporting the process of making decisions in the tasks of designing and planning flexible systems.

\section{Instrumental measurements as a basis of automation of construction technological processes}

Modern methods of technologies, mechanization and automation of technological processes, project organization and management are interrelated and directed on attaining a common goal: reduction of terms and assurance of quality of construction work, extension of the life cycle duration of construction facilities. This goal may be attained by implementation of computer-aided systems of management, control and arrangement of technological processes with the use of information technologies and specialized software. In the construction industry operations are divided into the following types: mechanized, large-scale mechanized and automated.

In mechanized work (Fig. 4-a) the main operations are performed with the use of machines, equipment, plants and tools which have mechanical, electric, pneumatic, hydraulic or combined drives. During large-scale mechanized work all labor-intensive operations and processes are mechanized. Machines, equipment and other technological means are interrelated with productivity and provide for the rate of work set by a leading machine. 
Computer-aided processes are divided into partial, comprehensive and complete automation processes.

The partial automation provides for application of automated equipment, instruments and devices during some, mainly basic production operations. The most part of building machines and equipment are fitted up with such instruments and devices.

The large-scale automation provides for application of a system of some units, machines, instruments and devices which are combined as a single process line and perform all operations of a production process. At that the operator performs only the start and stop operations; the set parameters of the production process are maintained automatically at all its stages.
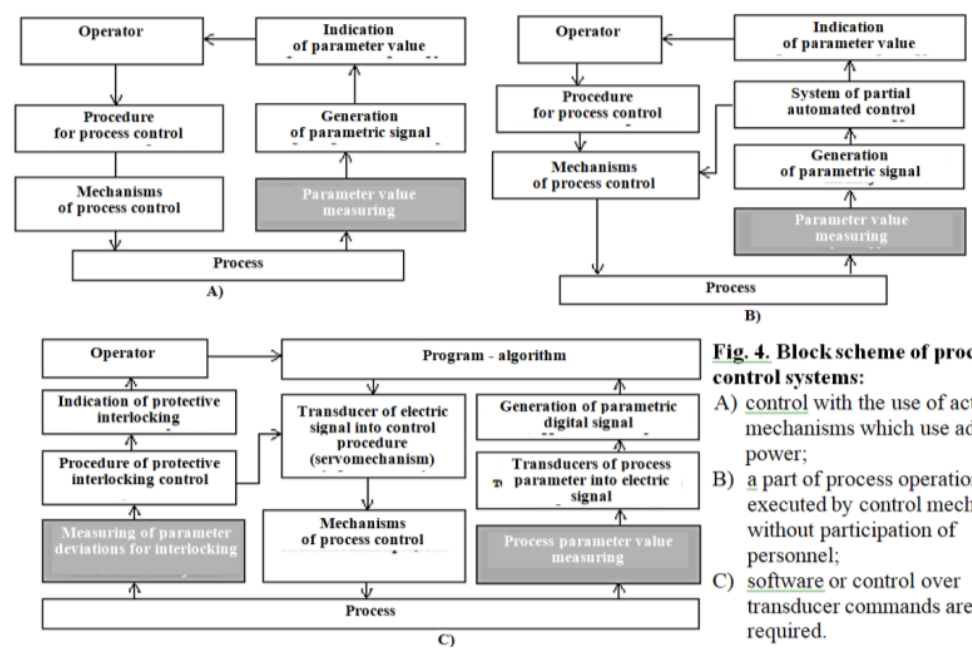

Fig. 4. Block scheme of process control systems:

A) control with the use of actuating mechanisms which use additional power;

B) a part of process operations is executed by control mechanisms without participation of personnel;

C) software or control over transducer commands are required.

The complete automation ensures fulfillment not only all basic but also auxiliary production operations as well as conduction of automatic control and process monitoring including changes in parameters and types of products in accordance with a specified program.

Means of automation are divided into controlling, protecting, regulating and monitoring devices. A process automation system provides for utilization of various combinations of the above types of devices. Control functions may be divided into non-automatic, automated and automatic ones according to a degree of participation of a person in them. The non-automatic process control may be manual or mechanized. Under manual control a person determines the required control actions on his (her) own, performs and checks them visually or by indications of elementary instruments. Under mechanized process control 
(Fig. 4, A) actuating mechanisms that consume additional energy (electrical, compressed air or working fluid etc.) are used. At that the instruments via corresponding transducers only inform the operator about process disturbances.

Under automated control (Fig. 4, B) a part of process operations is performed by control mechanisms without participation of any person. In this case the transducer signals of process disturbances are received not only by alarm devices but also by servomechanisms. The latter affect the control mechanisms on their own. They can stop actions of tools or the whole machine. The remained working functions of the operator are trouble-shooting, machine restarting and others.

The automatic control (Fig. 4, B) provides for control over transducers or software commands. This system comprises two basic parts: controlling and monitoring. Under such a control system a person is only engaged in preliminary installation of a certain program (algorithm), trouble-shooting in accordance with the transducers' signals (adjustment and repair of mechanisms) and starting the machine into operation or its turning off. At that a person only inserts a code of a required control program for obtaining the required result. Processes are controlled with the use of an automatic control system (ACS) that is an assembly of a facility under control and control device that interact without participation of any person.

According to the block schemes of the process control systems shown in Figure 4 the procedure of any type of automated process consisted of operations of obtaining and processing data, making and implementing process control decisions includes elements that provide for instrumental measurements and processing of the data related to a process parameter under control.

Therefore the reduction of terms of construction work and the extension of terms of building operation is an urgent technical and economic issue that will require effective solutions at all stages of the life cycle such as survey and design work, preparation work, earthwork, construction of ground structures, operation, period of deterioration and life cycle termination or beginning a new life cycle subject to renovation of facility serviceability.

The scientific problem is a necessity of theoretical substantiation of extension of the terms of operation and reduction of the terms of construction work for account of the effective automatic control over organizational and technological processes with the use of basic data obtained by the methods of instrumental measurements at all stages of the life cycle of building facilities. The scientific substantiation and development of methodological principles of generation of organizational and technological solutions of automatic process control with the use of basic data obtained by methods of instrumental measurements at all stages of the life cycle of building facilities are objects of further studies. 
Objects of studies are organizational and technological solutions of automatic control over organizational and technological processes with the use of building information models and data obtained by instrumental methods and measurement means, independent or integrated into the automatic control system.

Subjects of studies are parameters of organizational, technological and technical solutions of automatic control over organizational and technological processes with the use of building information models and data obtained by instrumental methods and means of measurements, independent or integrated into the automatic control system.

The scientific conception consists in a possibility of reduction of the terms of construction work and extension of the terms of operation of buildings and structures for account of implementation of effective organizational and technological as well as engineering solutions of automatic process control issues with the use of building information models and data obtained by methods of instrumental measurements at all stages of the life cycle.

Thereby the development of integrated models and methods for the system of automated diagnostics of building facility operating conditions is a major step for establishment of an integrated automated system that will ensure the serviceability of buildings and structures at all stages of their life cycles.

\section{Research into mechanisms of influence of technologies and organization of measuring work on duration of building life cycles}

In the process of research into mechanisms of influence of technologies and organization of measuring work on life cycle duration of building facilities it has been established that the building life cycle duration may be increased when risks of emergencies are timely detected and the corresponding measures are taken in proper time. Prediction of the longevity parameter is based on estimations of probabilistic-statistical models with the use of data of instrumental examinations of states of structures.

It has been revealed that the building life cycle duration is affected by general factors, as well as engineering and performance factors. In the long run building depreciation is aggravated nevertheless it may be less intensive if the results of instrumental examinations are used and the building serviceability is maintained for account of repair and rehabilitation work. Untimely execution of such work results in an increase of expenditures on restoring of necessary service characteristics and emergencies in a case of an ungrounded increase in the period between overhauls (Fig. 5). 


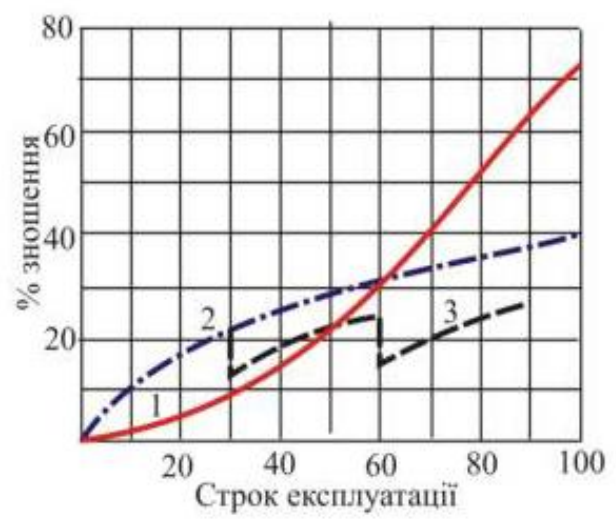

Fig. 5. Depreciation vs. building operating time:

1 - theoretical curve; 2 - actual data in a case of scheduled repairs;

3 - in a case of timely repair and rehabilitation work

During the life-cycle a set of measures for acquisition of information that is required for execution of work of the corresponding stage is implemented. The volume of this information defines the soundness of decisions made for maintaining facilities' performances at the required level. The developed topology of methods of instrumental measurements at the corresponding stages of construction and operation of facilities is presented in Fig. 6. It shows that at the construction stage the measuring operations are performed simultaneously or sequentially with the construction operations.

When the efficiency of available measuring operations is evaluated the possibility of making allowances for all factors is not obvious as the affecting factors are fuzzy and the decisions to be made depend on technological, technical or metrological parameters, subjectivity of solutions chosen by work performers, natural factors. The variants of measuring operations to be performed, the factors affecting the selection of measuring methods to be used, the degree of relevancy and influence of factors in a particular variant are determined with the use of the method of expert estimations.

It has been established that the issue of selection of means and methods of instrumental measurements should be considered not only with allowance for accuracy but also with consideration of minimum terms, costs and quality of construction and measuring work to be 
performed. At that, the arrangement and technology of work may be designed in such a manner that irrespective of the scope of time spent on measuring operations the reduction of time spent on fulfillment of construction processes will be significant. The main risks of failures may occur during manufacturing of elements and structures, installation of structures, in the initial period of operation of buildings or during next stages. Theses risks may be a result of negative effects of loads and unforeseen factors including drawbacks of the system of operation, unjustified replacements of structural elements (Fig. 7).

A scheme of substantiation of efficiency of means and technologies of instrumental measurements of building parameters at all stages of the building life cycle on the basis of comparison of organizational and technological indices classified by their importance has been proposed. The basic indices are of general character. They characterize the efficiency criterion to the utmost when are used together with other indices. Such additional indices are applied in such cases when the effects of specific factors of the corresponding stages of the life cycle shall be additionally accounted for. The method for determination of work productivity for different variants of organization and technology, means and methods of measurements with allowance for organizational, technological and technical factors provides for establishment of three categories of productivity: design-estimated, technical and operating.

Interrelations and interference of measuring operations and the basic engineering processes are of principal importance. They are a cause of increased labor costs for both measuring and basic processes unless they are sufficiently substantiated (organizationally and technologically) in the design and operation documentation. It has been established that the organizational and technological conditions for execution of measuring operations depend on a stage of the facility life cycle and determine approaches to justification of time expenditures for such work. 


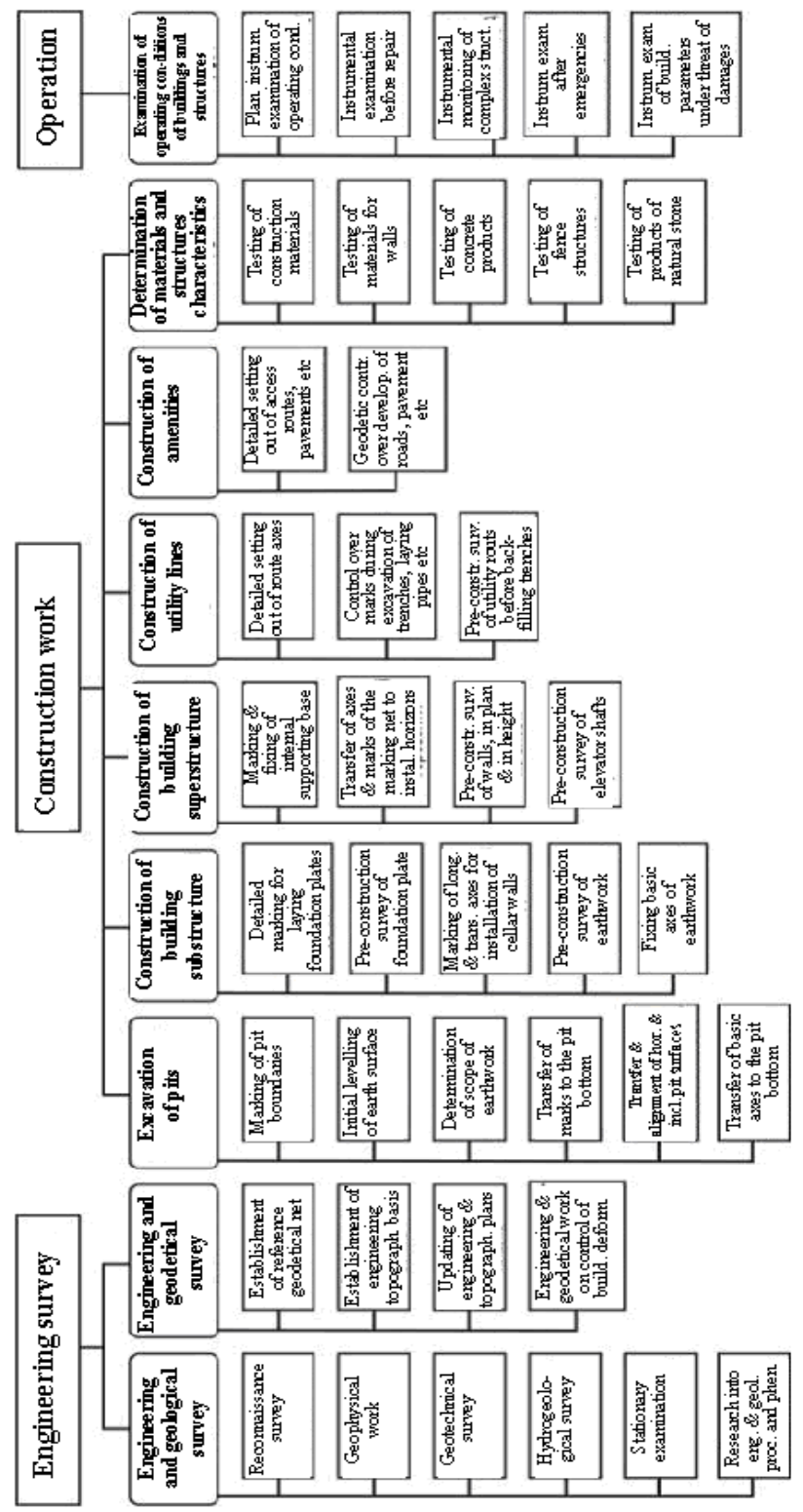

Fig. 6. Topology of instrumental measurement methods during construction and operation of building facilities 


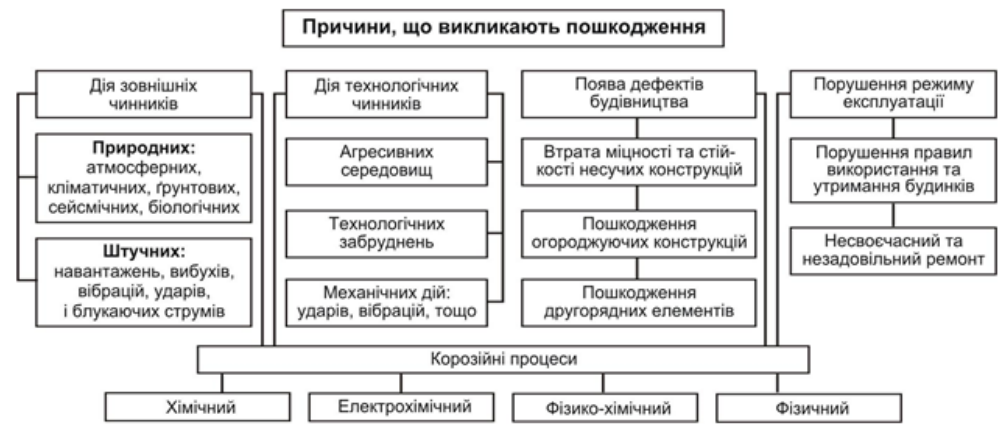

Fig. 7. Causes of occurrence of damages in buildings

Figure 8 shows a developed scheme of the method for substantiation of efficiency of measuring systems with the use of models and procedures of provision of building serviceability. The method is based on an algorithmic simulation of comprehensive processes used for determination of parameters of buildings, structures and development areas by instrumental methods together with some optimization parametric models for improving the efficiency of measuring work. Such an approach allows us to enlarge structurally and consolidate the performed parametric optimization. The mathematical model of linear dynamic system may be composed on the basis of mathematical models of elements and sections which form the system. Generally, the linear system includes sections that are joined sequentially or in parallel, surrounded by back or cross-back links. A block scheme of implementation of the comprehensive process of provision of serviceability and safety of buildings at all stages of the life cycle has been developed.

Combined modelling of the comprehensive process of measuring operations and some optimization parametric models for improving their efficiency provides for application of models and methods of determination of organizational and technological indices, establishment of a system for estimation and diagnostics of building operating conditions at all stages of the life cycle for development of recommendations on organization and process of parameter determination for buildings, structures and development areas in the design, engineering and operation documentation.

The recommendations on organization and process of parameter determination for buildings, structures and development areas for application in the design, engineering and operation documentation have been developed and included in the current normative documents. 
Аналіз та вибір етапів життєого циклу для впровадження системи будівельно-виміювальних робіт

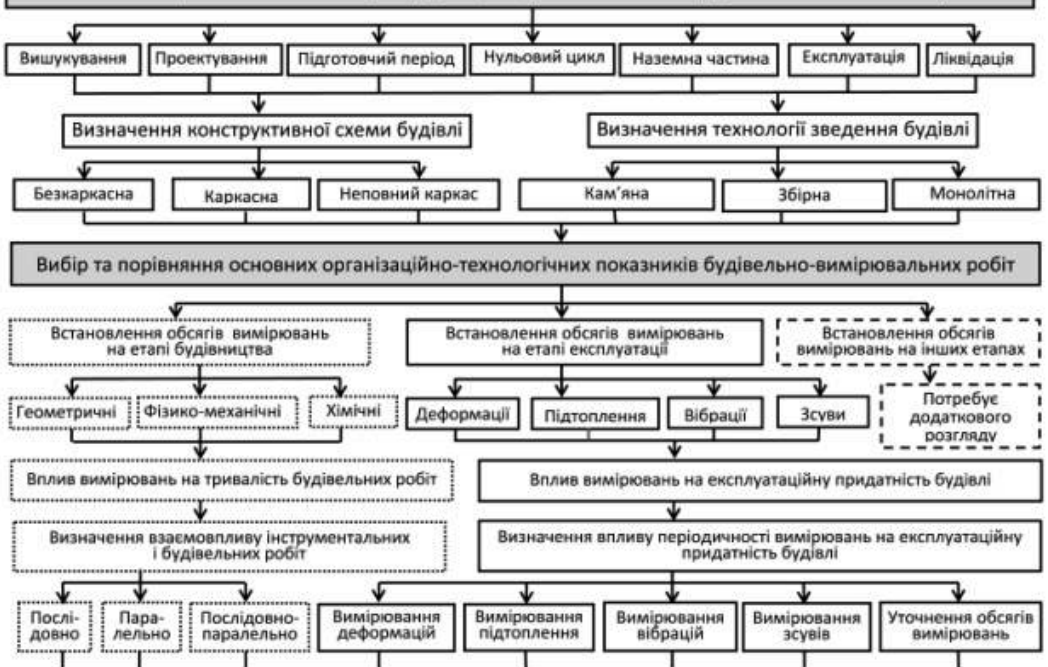

Вибір та порівняння додаткових організаційно-технічних показників будівельно-вимірювальних робіт

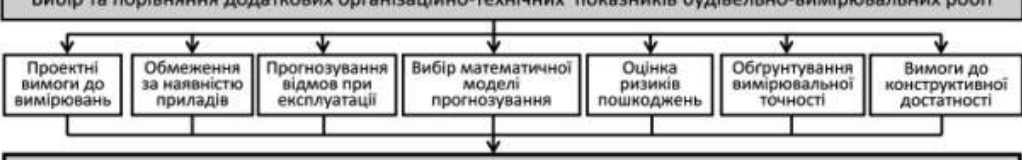

Визначення витрат часу та трудовитрат будівельно-вимірювальних робіт, з врахуванням чинників впливу.
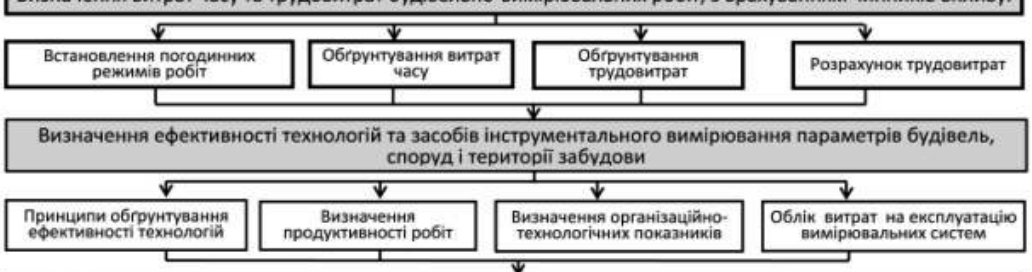

Порівняння та вибір вимірювальних систем 3 використанням моделей і методів формування системи експлуатаційної придатності будівель

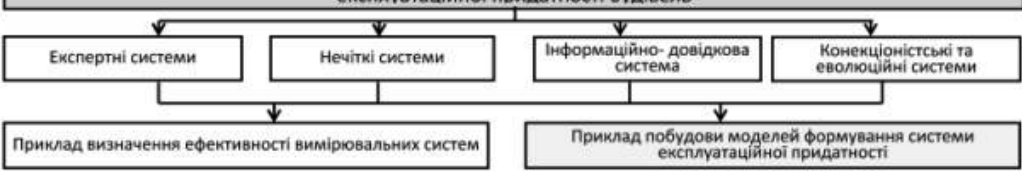

Fig. 8. Block scheme of modelling a comprehensive process of determination of serviceability at all stages of the building life cycle 


\section{CONCLUSIONS}

Modern methods of technologies, mechanization and automation of technological processes, project organization and management are interrelated and directed on attaining a common goal: reduction of terms and assurance of quality of construction work, extension of the life cycle duration of construction facilities.

This goal may be attained by implementation of effective organizational and technological as well as technical solutions for automated control of processes with the use of building information models and technologies, and information obtained by methods of instrumental measurements at all stages of the life cycle.

In this connection the development of integrated models and methods of automated system of diagnostics of building facilities operating conditions is one of the basic stages of designing a comprehensive automated system for ensuring the serviceability of buildings and structures at all stages of their life cycles.

Irrespective of a type of automated process the chain consisted of operations of data acquisition and processing, making and implementing decisions on controlling processes also comprises instrumental measurements and processing of data related to values of the technical parameter under control.

Automated process control and management systems may be developed on the basis of systems of instrumental monitoring of building serviceability at all stages of the life cycle. An automated monitoring system is a basis of any system designed for process controlling at all stages of the life cycle.

Such a system shall account for factors of influence on serviceability of buildings. The basic and additional performance indices account for economic, technical, technological and organizational factors of influence on the efficiency of automated systems.

\section{SUMMARY}

Methods of technologies, mechanization and automation of technological processes, project organization and management are interrelated and directed on attaining a common goal: reduction of terms and assurance of quality of construction work, extension of the life cycle duration of construction facilities, for account of organizational and technological as well as technical solutions for automated control of processes with the use of building information models and technologies, and information obtained by methods of instrumental measurements at all stages of the life cycle. The development of integrated models and methods of automated system of diagnostics of building facilities operating conditions is an initial stage of designing a comprehensive automated system for ensuring the serviceability 
of buildings. The automated system comprises integrated components for instrumental measurements and data processing. Therefore the measurements are the basis for automation of processes at all stages of the building life cycle.

\section{REFERENCES}

1 Havryliak A.I. Operation, reconstruction and modernization of buildings / A. I. Havryliak, I. B. Bazarnyk, R. I. Kinash et al. - L'viv: Publisher National University «L'vivska politekhnika», 2006. - 537 p. (in Ukrainian).

2 Astaf'eva N.S., Kibireva Yu.A, Vasil'eva I.L. Advantages of application and difficulties of implementation of the building information modelling // Construction of unique buildings and structures. ISSN 2304-6295. 8 (59). 2017. P. 41-62 (in Russian).

3 Talapov V.V. Building information modelling - modern conception // CADmaster. 2010. No. P. 114-121 (in Russian).

4 Chikovskaia I.I. Implementation of BIM - experience, scenarios, mistakes, conclusions // SAPR and Graphics. 2013. No. 8. P. 18-22 (in Russian).

5 Krinitskii E.V., Yakubson V.M., Vatin N.I. Building information modelling (BIM) // Engineering and building journal 2010. No. 2(12). P. 16-18 (in Russian).

6 Kozlov I.M. Estimation of economic efficiency of implementation of the building information modelling //AMIT. 2010. No. 1(10). P. 1-9 (in Russian).

7 Demenev A.V., Artamanov A.C. Information modelling in the process of operation of buildings and structures // Sociology of science. 2015. No. 3. P. 1-9 (in Russian).

8 Talapov V.V. Technology of BIM. Essence and peculiarities of implementation of the building information modelling. M.: Publisher DMK Press, 2015. $410 \mathrm{p}$ (in Russian).

9 Vorob'ev A., Danilova L., Ignatov B., Ryndin A., Tuchkov A., Utkin A., Fertman I., Scheglov D. Scenario and mechanisms for developing a unified information space // CADmaster. 2010. No. 5. P. 48-51 (in Russian).

10 Zamataev D.V. Study of approaches to virtual modelling // Mining information-analytical bulletin (scientific and engineering journal). 2014. No. 9. P. 312-316. (in Russian).

11 Melikhov N.S., Kostiuchenko A.Yu., Yaschenko A.A., Narezhnaia T.K. Advantages of BIM in performing expert examination of design documentation // International scientific and research journal. 2016. No. 5-3. P. 143-145 (in Russian). 
12 Lushnikov A.S. Problems and advantages of implementation of BIM technologies in construction companies // Bulletin of civil engineers. 2015. No. 6. P. 252-256 (in Russian).

13 Seliutina L.G., Timofeev S.V. Analysis of foreign experience of development and application of information modelling technologies in construction // Problems of construction economics and management under conditions of environmentally sensitive development. Tomsk: Publisher: Tomsk State Architectural and Construction University, 2015. P. 324-329 (in Russian).

14 Perepelitsa F.A., Petukhova E.A. BIM standards in the world practice // Electronic scientific journal. 2015. No. 1(1). P. 561-566 (in Russian).

15 Manukhina L.A., Yaschenko A.A. Integration of organizational and technological solutions with BIM // Innovation technologies in science and education. 2015.No. 2(2). P. 246-249 (in Russian).

16 Talapov V.V. Principles of BIM: introduction into the building information modelling. M.: Publishers DMK Press, 2011. 392 p. (in Russian).

17 Ignatova E.V. Solving of problems on the basis of a building information model // Bulletin of MGSU. 2012. No. 9. P. 241-246 (in Russian).

18 Talapov V.V. BIM in Russia: new building of Mariinskii Theatre [Electronic resource] URL: http://isicad.ru/ru/articles.php?article_num= 14257 (date of visiting: 20.02.2016) (in Russian).

19 Mitrofanova N.O., Chernov A.V., Berezina E.V. Possible applications of BIM technologies // Interexpo Geo-Siberia. 2016. No. 2. P. 177-182 (in Russian).

20 Grakhov V.P., Mokhnachev S.A., Manokhin P.E., Ishtriakov A.Kh. Organizational improvements of design work by implementation of building information modelling technologies // Modern problems of science and education. 2015. No. 1-1. P. 615 (in Russian).

21 El'sheikh A.M. Information modelling in integrated computer-aided designing and scheduling in construction [Place of thesis defence: Moscow State Building University]: abstract of thesis for a candidate degree in technical sciences: 05.13.12, 05.02.22 / A.M. El'sheikh. M., 2015. 21 p. (in Russian).

22 Pailevanian B.S. Rising the level of environmental safety and energy consumption efficiency of buildings on the basis of intellectual technologies [Place of thesis defence: Moscow State Building University]: abstract of thesis for a candidate degree in technical sciences: 03.00.16 / B.S. Pailevanian. M., 2009. 23 p. (in Russian). 
23 Volynskov V.E. Information-technological methods of designing in architectural forming [Place of thesis defence: Moscow State Building University]: abstract of thesis for a candidate degree in architecture: 05.23.20 / V.E. Volynskov. - M., 2012. - 25 p. (in Russian).

24 Alekseev S.A., Tyshkevich A.V., Alekseeva A.S., Chernykhovskii B.A. Urgency of implementation of the building information modelling in construction // Scientific discussion: issues of technical sciences. 2016. No. 1(31). P. 7-11 (in Russian).

25 Talapov V.V. BIM is a basis // CADmaster. 2010. No. 4. P. 13 (in Russian).

26 Morozov V.S., Ort A.I. Designing: from vocation to self-education // St. Petersburg: Construction, Technologies, Organization. 2014. No. P. 14-15 (in Russian).

27 Malinovskii M.E. Information modelling technologies in design institutions // Anthology of world science. 2016. No. 4-1(7). P. 121-122 (in Russian).

28 Panteleev A.S. Substantiation of effects exerted by investments on economic growth of enterprises in the construction industry of the NorthWest Federal Region of the RF [Place of thesis defence: Peter the Great SPbPU]: graduate thesis: 38.04.01: defended on 13.09.16: approved on 13.09.16 / Panteleev Alexander Sergeevich; Peter the Great SPbPU - SPb, 2016. 113 p. (in Russian).

29 Postnov K.V. Application of BIM technologies for the management processes in design institutions // Scientific review. 2015. No. 18. P. 367-371 (in Russian).

30 Bachurina S.S., Golosova T.S. Investment component in BIM implementation projects // Bulletin of MGSU. 2016. No. 2. P. 126-134 (in Russian).

31 Del'tsova T.D., Afanas'eva T.V., Slepkova T.I. Efficiency of application of BIM technologies during reconstruction of facilities // Economy and Business. 2015. No. 6-3. P. 741-744 (in Russian).

32 Rumiantseva E.V., Manukhina L.A. BIM technologies: an approach to designing a construction facility as a single whole // Modern science: urgent problems and ways of their solving. 2015. No. 5(18). P. 33-36 (in Russian).

33 Chetverik N.P. Step-by-step implementation of information modelling technologies (BIM) in the construction sphere // Bulletin 2014 No. 12(191) P. 44-47 (in Russian).

34 Chernykh M.A., Yakushev N.M. BIM technology and program products on its basis in Russia // Bulletin. 2014. No. 1(61). P. 119-121 (in Russian). 
35 Talapov V.V. What does affect the implementation of BIM in Russia // SAPR and Graphics. 2010. No. 11(169). P. 12-16 (in Russian).

36 Chikovskaia I.I., Novozhenina I.N. Trends in development of BIM in Russia. SAPR and Graphics. 2014. No. 8(214). P. 8-11 (in Russian).

37 Eltyshev Yu.V., Kirillov A.I., Talapov V.V. BIM and metal structures: some examples // CAD-master. 2010. No. 4. P. 109-110 (in Russian).

38 Baiburin A.Kh. Comprehensive estimation of quality of building operations / A.Kh. Baiburin // Bulletin of URGU. - 2005. - No. 13. P. 68-70 (in Russian).

39 Halins'kyi O. Arrangement of building production [Text]: DBN A.3.1-5:2016. - [enforced from 2016-08-01] / O. Halins'kyi, P. Hryhorovskiy, A. Kotliarenko et al. - K.: Minregionbud of Ukraine, 2016. - 51 p. - (State building code of Ukraine) (in Ukrainian).

40 Hryhorovskiy P.Ye. Method for determination of a compactness factor around a new construction facility / P.Ye. Hryhorovskiy, M.I. Nadtochii // Development management for complex systems: collection of scientific papers - K.: KNUBA. - 2013. - No. 16. - P. 181-183 (in Ukrainian).

41 Hryhorovskiy P.Ye. Application of operating condition monitoring for buildings and structures for studying geodynamic and man-caused processes of their construction and operation / P.Ye. Hryhorovskiy, I.V. Trevoho, N.P. Chukanova // Geoinformation environmental monitoring: GNSS and GIS technologies: Proceedings of XXVIII International Scientific and Engineering Symposium. 10-15 September 2013. - Alushta, 2013. P. 136-143 (in Ukrainian).

42 Hryhorovskiy P.Ye. Selection of optimal methods for monitoring of building structures operating conditions with the use of utility functions / P.Ye. Hryhorovskiy, N.P. Chukanova // New technologies in construction: collection of scientific and engineering papers $-\mathrm{K}$.: Publishers «Lira-K», 2014. - Issue. 27-28. - P. 21-24 (in Ukrainian).

43 Hryhorovskiy P.Ye. Details of calculations of costs of labor for conducting survey operations in construction / P.Ye. Hryhorovskiy, N.P. Chukanova // Modern achievements of the land-surveying science and production: collection of scientific papers of the West Geodetic Society UTGK. - L'viv: Publishers L'viv Polytechnika, 2014. - Issue 1(27). P. 148-151 (in Ukrainian).

44 Hryhorovskiy P.Ye. Monitoring of building structures inclination with the use of an electronic plumb rule / P.Ye. Hryhorovskiy, Yu.V. Deineka, V.O. Kosolap // Building production: collection of scientific and technical papers - K.: TsP «Comprint», 2009. - Issue. 50. - P. 8-10 (in Ukrainian). 
45 Hryhorovskiy P.Ye. Normative provisions for determination of estimated costs and labor intensities of construction work under restricted conditions / P.Ye. Hryhorovskiy, M.I. Nadtochii // Options for improvement of construction efficiency under conditions of formation of market relations: collection of scientific papers - K.: KNUBA - 2010. - No. 22. - P. 87-93 (in Ukrainian).

46 Hryhorovskiy P.Ye. Experience of conducting geodetic monitoring during reconstruction of the National Sports Complex 'Olimpiiskyi' / P.Ye. Hryhorovskiy, Yu.V. Deineka // New technologies in construction: collection of scientific and technical papers - K.: Publishers «Lira-K», 2010. - Issue 19. - P. 18-20 (in Ukrainian).

47 Hryhorovskiy P.Ye. Composition of knowledge base for an information expert system for selection of methods to be used during performance of survey operations in construction / P.Ye. Hryhorovskiy, Yu.V. Deineka, V.O. Kosolap // New technologies in construction: collection of scientific and technical papers - K.: Publishers «Lira-K», 2011. - Issue 21. - P. 48-51 (in Ukrainian).

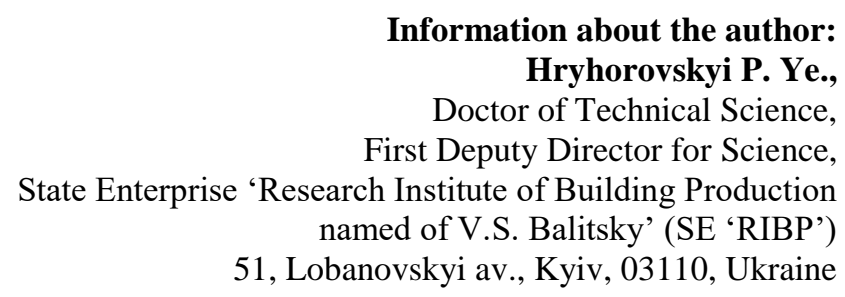




\title{
MULTIPLE CRITERIA MODEL FOR PROVING INVESTMENT AND CONSTRUCTION PROJECT EFFICIENCY
}

\author{
Stetsenko S. P.
}

\section{INTRODUCTION}

The work is based on the research of leading scientists in the field of investment science and construction economics, presented in the monographs and articles by A. Gojko, L. Sorokina, V. Fedorenko, P. Kulikov, G. Rizhakova, I. Ivahnenko, O. Tugaj, T. Vlasenko, O. Bielienkova, K. Izmajlova та ін. The analysis of literature sources reveals that the individual means of project economic evaluation while building construction investment portfolio do not take into account complex investment risks, differentiated by their individual types, as well the liquidity of developer's future assets, which significantly limits the ability to make informed decisions.

It is revealed that the concept of «liquidity» in the investment process is synthetic and requires a double reflection on different objects:

- in relation to investment objects, liquidity should be linked to the need to assess construction investment assets for their compliance with the planned values at all stages of the construction investment project implementation - from unfinished construction to finished construction products - and, further, to the object of profitable commercial use or social purpose $^{1}$;

- the second important aspect of the concept of «liquidity» is related to the need to evaluate the reliability of the investor as a leading subject of the investment and construction process as for the ability to achieve real investment goals by providing the appropriate level of liquidity balance and solvency of the organization in terms of 4 group indicators ${ }^{2}$.

This interpretation of the category of «liquidity» and the analysis of literature in several groups allowed us to formulate a scientific hypothesis of this work, which is as follows: "A leading requirement in providing a business process of real investment is a high level of liquidity of

\footnotetext{
${ }^{1}$ Izmajlova K.V. Finansovyj analiz: Navchalnyj posibnyk - 2-ge vydannya, stereotypne K.: MAUP, 2001. $-152 \mathrm{~s}$.

${ }^{2}$ Metodika zabezpechennya platospromozhnosti investora, likvidnosti aktiviv proektiv ta yih socialnoyi efektivnosti na bagatokriterialnij osnovi / V. O. Pokolenko, G. V. Lagutin, A. V. Shpakov ta in. // Zb. nauk. pr. «Komunalne gospodarstvo mist». - Harkiv: HNAMG, 2007. - Vip. 78. - S. 70-78.
} 
construction project assets and solvency of the investor". Therefore, in order to formulate a portfolio of construction projects, a new calculation and analytical multicriteria methodology should be proposed which will combine the criteria of liquidity of construction project assets, solvency, and social efficiency. The innovation base should be made up of innovative economic models. The applied result of the created models should be a technique embodied in a convenient methodological complex of applications for target users. Theoretical models and a complex of applications are designed to build rational investment portfolio in terms of volume, sources of financing, level of liquidity and profitability, as well as to ensure the proper level of liquidity and solvency of the organizations implementing construction investments. Therefore, the purpose of the article is to analyze the existing theoretical and methodological approaches to coordination of liquidity and efficiency of construction investments and solvency of investors, as well as to improve existing methods.

\section{Analysis of existing approaches, methods, and models to determine the investment priorities of the composition and structure of the investment portfolio}

The efficiency of investment activity depends on the level of capital construction development, investment, and industrial and construction complexes, which, in turn, is conditioned by production potential of their material and technical base, qualification of contractors, scientific and technical level of design decisions, status of investment process organization and planning, of providing it with financial resources. In the monograph ${ }^{3}$, the issues of revitalization of investment activity are related, first of all, to the need to transform the effective market mechanisms in the construction complex and to improve the economic and technological structure of investments. Among the main areas of « investment process restructuring» are the following ${ }^{4}$ :

1. Investment activity should be built on a single criteria basis: economic, environmental, social.

2. A clear distinction must be made between the areas of use of centralized and decentralized investment in their interconnection.

3. Reducing the duration of the investment cycle (3-4 times or more).

4. Improvement of the industrial, regional and technological structure of capital investments.

5. Increasing sources of investment.

\footnotetext{
${ }^{3}$ Investicijno-innovacijnij rozvitok pidpriyemnickoyi diyalnosti v Ukrayini. Monografiya / V. Fedorenko, P. Kulikov, G. Rizhakova, I. Ivahnenko. - 2019. - K. - 429 s.

${ }^{4}$ Shlyahi pidvishennya investicijnoyi diyalnosti v Ukrayini.: Monografiya./ za zag. redakciyeyu V.G. Fedorenka. - Nizhin: Aspekt-Poligraf, 2003. - 724 s. C. 34.
} 
6. Consistent decentralization of investment process, introduction of investment insurance system.

In Ukraine, at the present stage of economic development, intensification of financial and credit and investment markets is the main condition for the investment activity efficiency. Economic enhancement and investment activity can only be achieved through the creation of capital market. This task is multifaceted and contains both short-term and long-term aspects related to solving the problem of development of the equity and government securities markets. The latter is achieved through promotion of revenues and investments, as well as privatization funds.

Moreover, while building a rational composition of the investment portfolio, it is necessary to revise the criterion-parameter base.

The existing inappropriate approaches to building a construction investment portfolio (a complex of construction projects) mean to apply a traditional set of investment parameters that correlate the volume and pace of investment with the corresponding characteristics of net cash flows ${ }^{5}$.

Comparison of the above classification with the existing traditional system of economic feasibility of the construction investment portfolio allows us to claim that it is essential to improve the system of indicators (factors), used to analyse such a multidimensional category as risk of the corporate investment portfolio, there is a need to rationalize assessment characteristics while developing mathematical model. Since each of the existing quantitative investment risk assessment approaches such as flow comparison methods ${ }^{6}$, optimization methods and models, analogy method, sensitivity method, simulation modeling methods ${ }^{7}$, etc. do not provide a full appropriate assessment and growing requirements for the veracity of results, while developing economic models - theoretical research results and methods - practical research results - the benefits of each approach should be integrated.

One group of sources optimizes the investment structure by improving the organizational and technological decisions of investment projects and changing the negative component of the main project variable - net project income, saving from early commissioning of project fixed assets, as well as by organizational and technological distribution of project investment

${ }^{5}$ Fedorenko V. G., Gojko A. F. Investoznavstvo. / Za nauk. red. V. G. Fedorenka. - K.: MAUP, 2004. $-408 \mathrm{~s}$.

${ }^{6}$ Zelcer R.Ya. Innovacijni modeli i metodi organizaciyi, upravlinnya i ekonomichnoyi ocinki tehnologichnih procesiv budivelnogo virobnictva Kiyiv: «MP Lesya», 2018. 209 s.

${ }^{7}$ Izmajlova K. V., Byelyenkova O. Yu. Imitacijne modelyuvannya rozvitku budivelnogo pidpriyemstva [Elektronnij resurs] // Problemi sistemnogo pidhodu v ekonomici. - 2007. Vip. 4.- Rezhim dostupu: http : // www. nbuv. gov. ua/ e-journals / PSPE/20073/Belenkova_307.htm 
intensity in a manner suitable for the investor (providing in this regard sets of work transitivity requirements, safety requirements, standards of duration and labor intensity. The problem can be represented as follows:

$$
\begin{gathered}
\left\{\boldsymbol{\Omega}_{\mathbf{T}}^{\text {org }}(\mathbf{i})=\Delta \mathbf{P}^{+}(\mathbf{0}) *\left(\left[\Delta \mathbf{t}^{(\mathbf{P}-\ln v)}(\mathbf{0})-\Delta \mathbf{t}^{(\mathbf{P}-\ln v)}(\mathbf{i})\right] * / 365\right) * \boldsymbol{\alpha}\right\} \rightarrow \max , \\
\left\{\boldsymbol{\Omega}_{\mathrm{i}}^{\mathrm{org}}(\mathbf{i})=\text { ЧДД(i)- ЧДД (0) }\right\} \rightarrow \max ,
\end{gathered}
$$

$\mathbf{\Omega}_{\mathbf{T}}^{\text {org }}$ - the expected calculated effect of the implementation of the i-th option of the calendar investment plan, obtained by reducing the duration of development of investments and, therefore, by reducing the lag $\Delta \mathbf{t}^{(\mathbf{P}-\ln \mathbf{v})}$ in this option, compared with the original;

$\mathbf{\Omega}^{\mathbf{o r g}}$ - the expected intended effect obtained by changing the intensity of investment development from the implementation of the i-th option of the calendar investment plan, which leads to a comparative decrease in the negative NVP share, and, consequently, to the increase of the net consolidated income under this variant organizational and technological model implementation of the investment development plan;

$\Delta \mathbf{t}^{(\mathbf{P}-\ln \mathbf{v})}(\mathbf{0}), \Delta \mathbf{t}^{(\mathbf{P}-\mathbf{l n} \mathbf{v})}(\mathbf{i})$ - deferral lag duration of the project operational phase (in days) according to the initial and $\mathrm{i}$-th variant of the calendar plan;

$\boldsymbol{\alpha}$ - the calculated annual rate of discounting of investment flows (in unit particles);

$\Delta \mathbf{P}^{+}(\mathbf{0})$ - is the share of net payment flow from the sale of finished project product received for the released duration $\left[\Delta \mathbf{t}^{(\mathbf{P}-\ln \mathbf{v})}(\mathbf{0})-\Delta \mathbf{t}^{(\mathbf{P}-\ln \mathbf{v})}(\mathbf{i})\right]$ of the investment cycle.

These approaches do not take into account the impact between the main components of the project profitability and do not provide for the establishment of a calculated correlation between them, nor do they give reason to establish the investment priorities of the projects and to select projects in the investment portfolio, since their purpose is organizational and technological improvement of the performance of works calendar plan (development of investments) on the project ${ }^{8}$.

But this does not take into account the stochastic nature of the development of the investment situation, both in terms of the rate of investment development and the intensity of net cash flow receipts and the deferral lag $\Delta \mathbf{t}^{(\mathbf{P}-\ln \mathbf{v})}$.

The following group of sources gives grounds to set investment priorities for a fixed distribution of the components of net and net discounted income.

\footnotetext{
${ }^{8}$ Titok V. V. Formuvannya modeli zhitlovogo budivnictva v misti. Shlyahi pidvishennya efektivnosti budivnictva v umovah formuvannya rinkovih vidnosin. Kiyiv : KNUBA, 2013. Vip. 30. S. 90-99.
} 
According to one criterion (net or net consolidated income, profitability index, etc.), they set investment priorities and, depending on them, build up an investment program for the period, depending on the investment opportunities ${ }^{9}$.

The following approach proposes to use an integral criterion, which, on the basis of a combination of different investment indicators (selection criteria), gives grounds to set investment priorities. The formulation of the project selection task under this approach can be integrated as follows:

$$
\begin{gathered}
\operatorname{IKR}(\mathbf{i})=\left\|\mathbf{M a t r}_{\mathbf{i j}}\right\| *\left|\boldsymbol{\rho}_{\mathbf{j}}\right| *\left|\xi_{j}\right|, \quad \mathbf{i}=\mathbf{1}-\mathbf{n}, \quad \mathbf{j}=\mathbf{1}-\mathbf{m}, \\
\sum_{\mathbf{i}} \mathbf{B S}^{\ln \mathbf{v}}(\mathbf{i})<\mathbf{W}^{\ln \mathbf{v}}, \\
\mathbf{i}=\mathbf{1}-\mathbf{N}^{\wedge}, \quad \mathbf{N}^{\wedge}<\mathbf{n} .
\end{gathered}
$$

where IKR(i) - is the integral indicator (estimated criterion) of the priority of the $\mathrm{i}$-th project among their initial set $\mathrm{n}$;

$\mathbf{B S}^{\ln \mathbf{v}}$ - the total value (volume) of investments that the investor is able to provide during the settlement period;

$\mathbf{N}^{\wedge}$ - number of projects selected from the total volume by the prevailing IKR (i);

$\left\|\operatorname{Matr}_{\mathrm{ij}}\right\|$ - matrix of project evaluation by the criteria indicators (j) in their natural dimension (the columns of the matrix may be net consolidated income, profitability index, specific marginal revenue per unit of the project finished product, payback period, etc.);

$\left|\boldsymbol{\rho}_{\mathbf{j}}\right|$ - a vector that provides a transition from the natural dimension of $\mathbf{D}^{\mathbf{i n t}}{ }_{\mathbf{j}}$ to a single dimension and the consistency of $\mathbf{D}^{\mathbf{i n t}}{ }_{\mathbf{j}}$ growth direction with that of an integrated assessment of the IKR (i) project priority;

$\rho-$ a vector of weight rates that provide specific contribution of individual indicators to the integral $\mathbf{C} \mathbf{r}^{\text {int }}$ score.

In order to expand methodological tools in the construction economy, interesting innovative econometric approaches proposed for other industries were considered, and being flexible enough, they can be successfully used for construction industry. The following groups of sources are to be mentioned $^{10}$ :

\footnotetext{
${ }^{9}$ Tugaj O.A., Vlasenko T.V. Vdoskonalennya proektu na osnovi pidvishennya efektivnosti investicijnoyi diyalnosti / Shlyahi pidvishennya efektivnosti budivnictva $\mathrm{v}$ umovah formuvannya rinkovih vidnosin: zb. nauk. prac.-Kiyiv: KNUBA, 2019.- Vip. 39 u dvoh chastinah. Chastina 2. Tehnichnij. - S. 150-154.

${ }^{10}$ Bielienkova, O. Iu. (2007). Systema metodiv upravlinnia rozvytkom budivelnoho pidpryiemstva [System management development construction company]. Ekonomika ta derzhava - Economy and State, 9, 38-42 [in Ukrainian].
} 
- economic models of game theory implementation for building a rational portfolio of construction projects and sets of works;

- investment criteria balance method;

- modernized factor analysis method for building economic and mathematical model of effective management of enterprise's business and economic activity;

- correspondence matrix of production and financial resources, submitted in the works;

- econometric and diagnostic models designed to identify the leading factors of construction organization restructuring;

- the criteria to determine a degree of contractor risk proposed in the paper $^{11}$;

- search for a statistical criterion for the consistency of technological solutions from the complexity and duration of the BIS;

- search of statistical criterion for optimization of the calendar model of the housing construction industry, which includes several projects;

Outlined in the works of Pokolenko V.A. ${ }^{12}$ method of investment criteria balance initiates a specific methodology for creating construction investment cycle. This methodology in a single algorithm provides rational diagnostics of projects taking into account their profitability, volume and structure of investments, investor strategy and investment market business conditions, with further scenario-stochastic algorithm of pre-selection and final selection based on a new system of criteria. The final component of the method is the development and multi-criteria optimization of the calendar program for project implementation on several criteria, which increase stability of the organization - investor, high financial stability, maneuverability, return on assets and structure of investment cycle financing sources.

A significant step of updating the calculation and criterion base of creating a construction investment portfolio on a multicriteria basis is the work of Ryzhakova G.M. ${ }^{13}$, which suggested the investment framework foundation, alternative to the traditional approaches, and its multicriteria and phased economic diagnostics.

11 Ekonometrichnij instrumentarij upravlinnya finansovoyu bezpekoyu budivelnogo pidpriyemstva : [monogr.] / za nauk. red. d.e.n., prof. L. V. Sorokinoyi. - K. : Kiyivskij nacionalnij universitet budivnictva i arhitekturi; Krivij Rig : Vid. FOP Chernyavskij D. O., 2017. - C. 4-26.

12 Pokolenko V.O. Stohastichnij algoritm racionalizaciyi investicijnogo portfelya // Mizhvidomchij naukovo-tehnichnij zbirnik «Budivelne virobnictvo». - K.: NDIBV, 2002 № 42. - S. 74-77.

${ }^{13}$ Rizhakova G.M. Teoretichni osnovi ta praktichni algoritmi formuvannya portfelya budivelnih investicij shlyahom optimizaciyi obsyagiv ta strukturi podatkiv // Zbirnik naukovih prac Mizhnarodnogo institutu upravlinnya. - K.: MIU, 2005. 
As the first stage of rationale for composition and structure of construction investment portfolio ${ }^{14,15}$ offers a complex economic diagnostics of the separate projects suggested for the portfolio, considering variability of the change of their cost parameters during the investment cycle. The parameters to be varied at this stage are the leading cost indicators in the preinvestment and investment phase, direct and administrative-management costs for the types of works and sections of the consolidated budget, and, in the operational phase, these are indicators of business activity and financial stability of the studied object. Dependent variables (evaluation criteria) in the first stage are a minimum of variations in cost parameters based on the results of estimation of possible scenarios for the development of the investment situation using a random variable generator. This stage includes the development of a risk matrix, the columns of which are heuristically established stylistic descriptions of risks, and the rows of the matrix correspond to the list of arguments of situational variables. Depending on the level of risk, both the range of deviations and the frequency of nontypical events that do not comply with the directive ones change. With the help of a random variable generator, it is suggested to provide arguments to the model of variational values, taking into account the range and frequency set by the deviation matrices. The final operation of this step is to calculate the variation of cost parameters. On this basis, projects are approved or rejected by the investor.

In the second stage, the preliminary-formed construction investment portfolio is subject to optimization by several criteria - the objective functions. The minimum criteria for project taxation included in the portfolio and the criterion of investor reliability - the maximum amount of direct working assets - were selected as the leading criteria. The arguments for these criteria are the volume of project assets by type and the speed of their transformation over time.

The above methodological approaches to the investment project evaluation serve as a methodological prerequisite for improving the system of socio-economic efficiency of investments on a multicriteria basis ${ }^{16,17,18}$,

${ }^{14}$ Rizhakova G.M. Optimizaciya obsyagiv ta strukturi podatkiv yak kriterialna osnova viyavu formuvannya investicijnih program, ekonomiko-teoretichnij zmist ta programna realizaciya metodiki. // Naukovo-virobnichij zhurnal «Zemlevporyadnij visnik», № 4, 2005. - S. 79-81.

15 Tetyana Marchuk, Dmytro Ryzhakov, Galyna Ryzhakova and Sergiy Stetsenko (2017). Identification of the basic elements of the innovationanalytical platform for energy efficiency in project financing. Investment Management and Financial Innovations Vol. 14(4), pp. 12-20.

16 Mihels V.O., Bondar V.P. Ob'yednana strategiya ekonomichnogo upravlinnya pidpriyemnickim proektom: Monogr. /Pid zag. red. V.O.Mihelsa. - K.: KNUBA, 2003. - $200 \mathrm{~s}$.

${ }^{17}$ Gojko A. F. Metodi ocinki efektivnosti investicij ta prioritetni napryami yih realizaciyi / A. F. Gojko. - K. : Vira-R, 1999. - 320 c.

${ }^{18}$ Vahovich I. V. Sistema ekonomichnih metodiv optimizaciyi budivnictva : Avtoref. dis... kand. ekon. nauk : 08.07.03 / I. V. Vahovich; Kiyiv. nac. un-t bud-va i arhit. - K., 2004. - 19 c. 
emphasizing the need to take into account such factors as assets liquidity and solvency of the investor ${ }^{19}$.

\section{Economic and mathematical model of liquidity management of construction investment assets and ensuring their social efficiency on a multicriteria basis}

The ongoing process of structural transformation of the economic complex of the country, are followed by the need to reorganize the structure of real investments. This requires creation of such methodological and methods approaches to cost-effective diagnostics, selection and implementation of real investments, aimed not only at providing high term return for the investor, but also providing all participants of the investment process with the opportunity to carry out reliable and economically justified monitoring of the flow of assets and sources of construction investment projects and ensure high project liquidity, profitability and social efficiency. Existing techniques and models, as demonstrated in the first section of the paper, do not meet these requirements, focusing mainly on commercial appeal and using the traditional set of investment project evaluation indicators.

The need to create innovative theoretical and methodological foundations, which efficiently adjust the tasks of assessing the liquidity, profitability and social efficiency of construction investments, determines the scientific, theoretical and applied relevance of the proposed model.

Within the group of methods considered in a number of works ${ }^{20,21,22}$, the organization solvency and the liquidity of its balance are defined. Solvency of an enterprise is determined by its ability and possibility to timely and fully fulfill payment obligations arising from trade, credit and other transactions of a monetary nature. Solvency affects the forms and conditions of commercial affairs, including the possibility of obtaining a loan. Liquidity of an enterprise is determined by the availability of liquid assets to it, which include cash, funds on bank accounts and easily realized elements of

19 Pokolenko V.O. Metodika vdoskonalennya manevrenosti, finansovoyi stijkosti ta dilovoyi aktivnosti virobnichoyi programi budivelnih pidryadnih organizacij shlyahom multikriterialnoyi optimizaciyi // Shlyahi pidvishennya efektivnosti budivnictva v umovah formuvannya rinkovih vidnosin. - Vip. 10. - 2002. - S. 65-80.

${ }^{20}$ Bielienkova O.Yu., Antropov Yu.V. Ekonomichna stijkist malih budivelnih pidpriyemstv Ukrayini: ocinka, tendenciyi, perspektivi Problemi ekonomiki. - 2013. - № 3. - S. 51-62.

${ }^{21}$ Ekonometrichnij instrumentarij upravlinnya finansovoyu bezpekoyu budivelnogo pidpriyemstva : [monogr.] / za nauk. red. d.e.n., prof. L. V. Sorokinoyi. - K. : Kiyivskij nacionalnij universitet budivnictva i arhitekturi; Krivij Rig : Vid. FOP Chernyavskij D. O., 2017. - C. 4-26.

${ }^{22}$ Izmajlova K. V., Byelyenkova O. Yu. Imitacijne modelyuvannya rozvitku budivelnogo pidpriyemstva [Elektronnij resurs] // Problemi sistemnogo pidhodu v ekonomici. - 2007. Vip. 4. - Rezhim dostupu: http : // www. nbuv. gov. ua/ e-journals / PSPE/20073/Belenkova_307.htm 
working capital. Liquidity reflects the ability of an entity to make the necessary costs at any time.

Liquidity and solvency as economic categories are not identical, but in practice they are closely interdependent. The liquidity of the enterprise reflects the solvency of the debt. Enterprise's failure to repay its debt to its creditors and the budget forces it into bankruptcy. The grounds for declaring a company bankrupt are not only their failure to fulfill their obligations to the budget within a few months, but also the failure to fulfill the requirements of legal entities and individuals having financial or property claims against it. Improving the solvency of an enterprise is inextricably linked to a working capital management policy aimed at minimizing financial liabilities. In other words, profit is a long-term goal, but in the short term, even a profitable business can go bankrupt due to lack of funds.

The following basic techniques can be used to assess solvency and liquidity:

a) structural analysis of changes in the active and passive Balance Payments, that is, the analysis of the liquidity of the balance;

b) calculation of financial liquidity ratios;

c) analysis of cash flows during the reporting period.

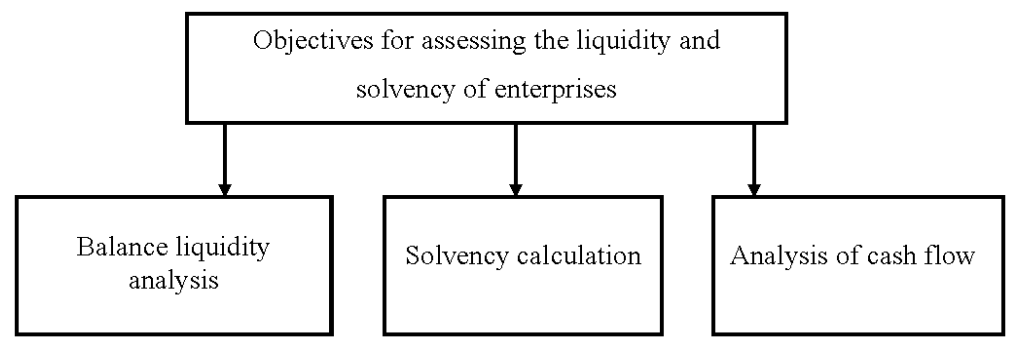

Fig. 1.1. Solvency and liquidity assessment tasks

While analyzing balance liquidity one compares the assets, grouped by degree of their liquidity, with liabilities for debit, (grouped by their maturity. Calculation and analysis of liquidity coefficients allows to identify the degree of security of current liabilities by liquidity funds. The main purpose of cash flow analysis - to evaluate the ability of the company to generate funds in the amount and in the time required to make the planned expenses and payments. The main task of assessing the accounting liquidity is to determine the amount of cover of the liabilities by an enterprise with its assets, whose term of transformation into monetary form (liquidity) corresponds to the term of repayment of liabilities (urgency of return). 
For analysis, the assets and liabilities of the balance are grouped by the following features ${ }^{23,24}$ :

- by the degree of liquidity reduction (assets);

- the degree of maturity (payment) (liabilities).

Assets, depending on the rate of conversion into funds (liquidity) are divided into the following groups:

A1 - the most liquid assets. These include cash from enterprises and short-term financial investments.

A2 - fast-selling assets: receivables for goods, services, accounts receivable and other current assets;

A3 - slow-moving assets - these include inventories and expenses, longterm financial investments;

A4 - hard-to-sell assets are defined as the difference between the value of non-current assets (total I section of assets) and long-term financial investments.

The grouping of liabilities occurs according to the degree of urgency of their return:

P1 - the forward liabilities - accounts payable for goods, works, and services, current settlement obligations, other current liabilities;

P2 - short-term liabilities which include short-term bank loans, current debt on long-term loans, promissory notes;

P3 - long-term liabilities. These include long-term bank loans, other long-term liabilities;

P4 - fixed liabilities. These are their own - summary of Sec. I of liabilities.

To provide the project investor (creditor) with a reliable and economically sound picture of the flow of project assets at different phases and elements of the investment cycle, an innovative model of multicriteria project valuation is proposed, which uses indicators of liquidity of projects and solvency of organizations as a leading requirement (criterion).

The following research methods and models were used as the methodological basis of the created model:

- system analysis - to determine the content and list of evaluation criteria and arguments that are part of the calculated evaluation criteria;

\footnotetext{
${ }^{23}$ Izmajlova K.V. Finansovyj analiz: Navchalnyj posibnyk - 2-ge vydannya, stereotypne K.: MAUP, 2001. $-152 \mathrm{~s}$.

24 Ekonometrichnij instrumentarij upravlinnya finansovoyu bezpekoyu budivelnogo pidpriyemstva : [monogr.] / za nauk. red. d.e.n., prof. L. V. Sorokinoyi. - K. : Kiyivskij nacionalnij universitet budivnictva i arhitekturi; Krivij Rig : Vid. FOP Chernyavskij D. O., 2017. - C. 4-26.
} 
- balance and structural method - for calculating values of model arguments based on the results of analysis of design estimates, feasibility studies, business plans, financial reporting on the results of the activities of organizations participating in the investment process;

- network models of «work-arc» with updated composition of parameters as the basis of process formalization of the investment cycle;

- models of optimization on several criteria and ways of their coordination.

The mathematical formalization of the problem is as follows. As model criteria it is suggested to use:

1) maximum of the immediate liquidity index of project $Z 1$ assets determined at the current moment of time by the ratio of the expert value of the finished finished product of the project and the unfinished construction to the volume of all obligations of the investor (co-investors) for the project (particles of unit);

2) the maximum of the absolute liquidity of the organizations-leading participants of the $\mathrm{Z} 2$ project - determined by the indexes of absolute liquidity of the investing organizations, in proportion to their shares in the assets (value) of the project at the moment (particles of unit);

3) maximum - the current liquidity of the leading participants of the $Z 3$ project - determined by the indexes of the current liquidity of investor organizations, in proportion to their shares in the assets (value) of the project at the moment (particles of unit);

4) maximum of the working capital of the investor organizations of the $\mathrm{Z} 4$ project, weighted average by their shares in the assets (value) of the project at the moment (UAH, in thousands)

$5)$ the minimum probability of bankruptcy of Z5 co-investor organizations is determined by the ratio of the difference between current assets and short-term liabilities to the balance sheet total for each of the coinvestor organizations, in proportion to their contribution to the value of all project assets (particles of unit).

6) the maximum turnover of project Z6 assets, determined by current periods (months or quarters), taking into account the time factor due to the ratio of the total volume of sales in value (excluding VAT, excise duties and other payments) to the value of all the assets invested in the project (units);

7) the maximum social efficiency of the $\mathrm{Z7}$ project, determined by the ratio of the amount of revenues to treasuries at all levels by way of value added tax, excise duties, other deductions from the volume of sales of products (services, BIS), income tax, payments to the payroll, to the estimated duration of the investment cycle, (UAH, in thousands / year);

Arguments (independent variables) for all calculation criteria are: 
- current time coordinates - months, quarters, years for which the investment situation for each of the submitted projects is examined;

- determined by periods the value of fixed and current assets invested in the project, taking into account the shares of co-investing organizations, UAH, in thousands;

- the volume of sales of the project products in terms of value (excluding VAT, excise duties and other payments), UAH, in thousands;

- total payroll for all types of work, costs, project participants at the current time, UAH, in thousands;

- total rate of aggregate payments to the payroll fund, particle of unit;

- profit (financial result) of economic activity of all participating organizations at the moment, $\mathrm{UAH}$, in thousands;

- the rate of taxation of profits, particle of unit.

In accordance with the defined content of criteria and arguments, the formulation of the problem, according to this economic model, reflects the following system of equations and inequalities (4):

$$
\begin{aligned}
& Z_{1}(t)=\left[s_{11}(t)+s_{12}(t)\right] / s_{13}(t) ; \\
& \mathbf{Z}_{2}(t)=\sum_{h=1-: H} \Omega_{h}\left[s_{21}(t, h)+s_{22}(t, h)\right] / s_{23}(t, h) ; \quad \Omega_{h}=W_{h} / W_{\Sigma} ; \\
& \mathbf{Z}_{3}(t)=\sum_{h=1:: H} \Omega_{h} s_{31}(t, h) / s_{32}(t, h) ; \quad s_{32}(t, h)=s_{23}(t, h) ; \\
& \mathbf{Z}_{4}(t)=\sum_{h=1: H} \boldsymbol{\Omega}_{\mathbf{h}}\left[\mathbf{s}_{41}(t, h)-\mathbf{s}_{42}(t, h)\right] ; \\
& s_{41}(t, h)=s_{31}(t, h) ; \quad s_{42}(t, h)=s_{43}(t, h) ; \\
& \mathbf{Z}_{5}(t)=\sum_{h=1: \mathrm{H}} \boldsymbol{\Omega}_{\mathrm{h}} \mathbf{s}_{51}(t, h) / \mathbf{s}_{52}(t, h) ; \mathbf{s}_{51}(t, h)=\mathbf{s}_{41}(t, h)-\mathbf{s}_{42}(t, h) ; \\
& \mathbf{Z}_{6}(t)=\sum_{t=1-:-T}(1 / t) *\left[\mathbf{s}_{61}(t)+\mathbf{s}_{62}(t)+\mathbf{s}_{63}(t)\right] /\left[\mathbf{s}_{64}(t) *\left(1+\alpha^{(\Delta t)}\right)\right] ; \\
& \Delta \mathbf{t}=\mathbf{t}-\mathbf{t}_{\mathbf{0}} \text {; } \\
& \mathbf{Z}_{7}(\mathbf{t})=\sum_{\mathbf{t}=1-:-\mathrm{T}}\left[\mathbf{s}_{71}(\mathbf{t})+\mathbf{s}_{72}(\mathbf{t})+\mathbf{s}_{73}(\mathbf{t})\right] / \mathbf{s}_{74}(\mathbf{t}) ; \quad \mathbf{s}_{74}(\mathbf{t})=\mathbf{s}_{61}(\mathbf{t}) ; \quad(4 . \mathrm{g}) \\
& \left\{\mathbf{Z}_{1}(\mathbf{t}), \mathbf{Z}_{2}(\mathbf{t}), \mathbf{Z}_{3}(\mathbf{t}), \mathbf{Z}_{\mathbf{4}}(\mathbf{t}), \mathbf{Z}_{6}(\mathbf{t})\right\} \rightarrow \max ; \quad \mathbf{Z}_{7}(\mathbf{t}) \rightarrow \min
\end{aligned}
$$


$\boldsymbol{\Omega}_{\mathrm{h}}$ - share of co-investor organizations in the total value of project assets;

$\mathbf{W}_{\Sigma}$ - the total cost of all investment in the project;

$\mathbf{W}_{\mathbf{h}}-$ the cost of the investment provided for investment by the h-th organization;

$\mathbf{s}_{11}-$ expert cost of the finished product created by the project;

$\mathbf{s}_{\mathbf{1 2}}$ - the same, unfinished construction;

$\mathbf{s}_{13}$ - cost of all commitments to the submitted project at the current time;

$\left[\mathbf{s}_{21}(\mathbf{t}, \mathbf{h})+\mathbf{s}_{\mathbf{2 2}}(\mathbf{t}, \mathbf{h})\right] / \mathbf{s}_{\mathbf{2 3}}(\mathbf{t}, \mathbf{h})$ is the absolute liquidity index of an h-th organization;

$\mathbf{s}_{21}(t, h), \mathbf{s}_{22}(t, h), \mathbf{s}_{23}(t, h)=\mathbf{s}_{32}(t, h)-$ respectively the cash, current financial investments and current liabilities of the $h$-th organization at time $t$;

$\mathbf{s}_{31}(t, h)=\mathbf{s}_{\mathbf{4 1}}(\mathbf{t}, \mathbf{h})$ - value of circulating assets of the h-th organization at time t;

$\mathbf{S}_{51}(\mathbf{t}, \mathbf{h})$ - the net working capital of an h-th organization at time $t$ is the difference between the value of current assets and current liabilities;

$\mathbf{S}_{\mathbf{5 2}}(\mathbf{t}, \mathbf{h})$ - a summary of the balance of the h-organization at time $t$;

$\mathbf{s}_{61}(\mathbf{t})$ - the volume of sales of products in terms of value under this project for the current period (excluding VAT, excise duties and other payments);

$\mathbf{s}_{\mathbf{6 2}}(\mathbf{t})$ and $\mathbf{s}_{\mathbf{6 3}}(\mathbf{t})$, respectively - the amounts of income tax and payroll contributions attributed to this project by all participating organizations;

$\mathbf{S}_{64}(\mathbf{t})$ - the amount of investment specified for investment in this project for the current period;

$\mathbf{t}_{\mathbf{0}}$ - is the period of time for which the value is adjusted (discounted);

$\left(\mathbf{1}+\boldsymbol{\alpha}^{(\Delta t)}\right)$ - is the denominator of discounting;

$\Delta \mathbf{t}-$ is the difference between the current time coordinate and $\mathrm{t}_{0}$.

Initial data for calculating model arguments is information on the structure of project assets (non-current, current) and sources of their financing (by investors), data on the components of the project cash flow (sales revenue, profitability of production and sales, salary, etc.), as well as information on the financial position of the leading participants in the investment process according to the public financial statements.

Based on the link between the content of $\mathbf{s}_{11^{-}}:-\mathbf{s}_{74}$ model arguments (dependent variables) in equations (1) - (4) with the volumes and structure of the estimated cost of projects, they can be presented as algebraic functions that combine the following investment characteristics (5):

$$
\left\{\mathbf{s}_{11^{-}:-s_{74}}\right\}=\mathbf{f}\left(\mathbf{W}_{\mathrm{mh}} ; \mathbf{X m o a} ; \mathbf{t}\right) \text {, }
$$




$$
\begin{aligned}
& \mathbf{W}_{\mathrm{mh}}=\boldsymbol{\Omega}_{\mathrm{mh}} * \mathbf{W}_{\mathrm{m}} * \boldsymbol{\delta}_{\mathrm{mh}} ; \sum_{\mathrm{m}=\mathrm{i}-:-\mathrm{M}} \sum_{\mathrm{h}=\mathrm{i}-:-\mathrm{H}} \mathbf{W}_{\mathrm{mh}}=\mathbf{W}_{\Sigma} ; \boldsymbol{\delta}_{\mathrm{mh}}=\{\mathbf{1} ; \mathbf{0}\}, \\
& \lambda_{\mathrm{m}}{ }^{\text {oa }}+\lambda_{\mathrm{m}}{ }^{\text {на }}=1 ; \lambda_{\mathrm{m}}{ }^{\text {oa }}=\mathbf{O A}_{\mathrm{m}} / \mathrm{W}_{\mathrm{m}} ; \lambda_{\mathrm{m}}{ }^{\text {на }}=\mathbf{H A} \mathbf{A}_{\mathrm{m}} / \mathbf{W}_{\mathrm{m}} ; \mathbf{H A}_{\mathrm{m}}+\mathbf{O A _ { m }}=\mathbf{W}_{\mathrm{m}}
\end{aligned}
$$

where $\mathbf{W}_{\mathbf{m h}}-$ is the anticipated amount of investment by the h-th organization of the $\mathrm{m}$-th construction project, which is proposed as a part of the investment program;

$\lambda_{m}{ }^{\text {ra }}$ - the share of non-current assets of the m-th project in its total value;

$\lambda_{\mathbf{m}}{ }^{\mathbf{a}}$ - the same for current assets;

$\boldsymbol{\delta}_{\mathbf{m h}}-$ an indicator of the h-th organization's involvement in the investment process of the $\mathrm{m}$-th construction project (if $\mathrm{h}$-th organization participates in the investment, then $\boldsymbol{\delta}_{\mathbf{m h}}=\mathbf{1}$, if not - then $\boldsymbol{\delta}_{\mathbf{m h}}=\mathbf{0}$ );

$\boldsymbol{\Omega}_{\mathbf{m h}}$ - the proportion of assets in the $\mathrm{m}$-th project that belongs to the h-th organization, the indicator of the distribution of project assets by their future owners;

$\mathrm{M}$ - number of projects in the investment program;

$\mathrm{H}$ - number of co-investor organizations participating in the investment program

Taking into account equations (4), the mathematical formulation of the problem in the form (5) is transformed into the form (6):

$$
\begin{gathered}
\mathbf{Z}_{\mathrm{i}}=\left\{\mathbf{Z}_{\mathrm{i}}(\mathbf{0})\right\}+\left\|\mathbf{a}_{\mathrm{ij}}\right\| * \mathbf{f}\left(\mathbf{W}_{\mathrm{mh}} ; \boldsymbol{\lambda} \mathbf{m}_{\mathrm{oa}} ; \mathbf{t}\right) ; \quad \mathrm{s}=\mathrm{l-:}-\mathbf{7} ; \mathbf{Z}_{\mathrm{i}}=\left\{\mathbf{Z}_{1}, \mathbf{Z}_{2}, \ldots, \mathbf{Z}_{7}\right\} \\
\mathbf{Z}_{\mathrm{i}}(\mathbf{0})=\mathbf{Z}_{\mathrm{i}} \text { при } \mathrm{t}=\mathbf{T 0}
\end{gathered}
$$

Where $\mathbf{Z}_{\mathbf{i}}$ - is the vector of criteria values;

$\mathbf{Z}_{\mathbf{i}}(\mathbf{0})$ - is the vector of initial conditions that determine the values of the benchmarks at the beginning of the $\mathbf{T}_{\mathbf{0}}$ investment process.

The optimal alternative to the investment program is sought by the individual criteria $\mathbf{Z}_{\mathbf{1}}, \mathbf{Z}_{\mathbf{2}}, \ldots, \mathbf{Z}_{\mathbf{7}}$ is sought using the monocriteria optimization algorithms $\mathbf{Z}_{\mathbf{1}}(\mathbf{t}), \mathbf{Z}_{\mathbf{2}}(\mathbf{t})-\mathbf{Z}_{\mathbf{4}}(\mathbf{t}), \mathbf{Z}_{6}(\mathbf{t}), \mathbf{Z}_{7}(\mathbf{t}) \rightarrow \max ; \mathbf{Z}_{5}(\mathbf{t}) \rightarrow$ min by changing the movable $\mathbf{W}_{\mathbf{m h}}$ parameters and the start times of the tm investment process for individual projects within the established limits as to these parameters and requirements as to the volume, structure, sources and intensity of investments.

The investment program that is optimal for all criteria is sought within the same limits by a linear combination of local solutions (7) using the weight coeffient Ui of the contributions of local $\mathbf{Z}^{\text {opt }}{ }_{\mathbf{i}}$ solutions to the total $\mathbf{Z}^{\text {opt. }}$ : 


$$
\mathbf{Z}^{\text {opt }}=\sum \check{\mathbf{U}}_{\mathbf{i}} * \mathbf{Z}^{\text {opt }} ; ; \quad \quad \mathbf{i}=1-:-7 ; \quad \check{\mathbf{U}}_{\mathrm{i}}=\mathbf{0 - : - 1 ;} \quad \sum \check{\mathbf{U}}_{\mathbf{i}}=\mathbf{1}
$$

The proposed model provides a sound scientific basis for selecting options for investment construction projects and resource and calendar models for their implementation. The proposed approach, due to the combination of local criteria of different content, ensures the growth of solvency and profitability of the activities of the leading participants of the investment process, and the conditions for ensuring high liquidity of project assets and their social efficiency.

\section{CONCLUSIONS}

The developed economic and mathematical model of liquidity management of construction investment assets offers an optimal alternative to the investment program sought by optimizing the structure and sources of investment. By local criteria, we seek to change the moving parameters of Wmh and the starting point of the investment process for individual projects within the limits set for these parameters, which reflect the requirements of ODA in terms of volume, structure, sources and intensity of investments.

4. The following are suggested as local criteria for optimization of investment programs:

I) maximum of the immediate liquidity index of project assets $Z_{1}-$ at the current moment determined by the ratio of the expert value of the created and finished product of the project and the unfinished construction to the volume of all obligations of the investor (co-investors) for this project (particles of unit);

II) maximum absolute liquidity of the organizations - the leading participants of the $Z_{2}$ project - determined by the absolute liquidity indices of the investor organizations, in proportion to their shares in the assets (value) of the project at the moment (particles of unit);

III) maximum - the current liquidity of the leading participants of the $Z_{3}$ project - determined by the indexes of the current liquidity of the investor organizations, and in proportion to their share in the assets (value) of the project at the current moment (particles of unit);

IV) maximum of the working capital of the investor organizations of the $\mathrm{Z}_{4}$ project, average weighted by their shares in the assets (value) of the project at the moment (UAH, in thousands);

$\mathrm{V})$ the minimum probability of bankruptcy of $\mathrm{Z}_{5}$ co-investor organizations is determined by the ratio of the difference between current assets and short-term liabilities to the balance sheet total for each of the co- 
investor organizations, in proportion to their contribution to the value of all project assets (units).

VI) maximum turnover of assets of project $Z_{6}$, determined by current periods (months or quarters), taking into account the time factor due to the ratio of the total volume of sales in terms of value (excluding VAT, excise duties and other payments) to the value of all assets invested in the project (units);

VII) maximum social efficiency of the $Z_{7}$ project, determined by the ratio of the amount of revenues to the budgets of different levels in the form of value added tax, excise duties, other deductions from the volume and sale of products (services, BIS), income tax, payments to the payroll, to estimated duration of the investment cycle, (UAH, in thousands / year);

The investment program that is optimal for all criteria is sought within the same constraints by a linear combination of local solutions using the weighting of the contribution of local solutions to the total. The proposed model provides a sound scientific basis for selecting options for investment construction projects and resource-calendar models for their implementation. The proposed approach, due to the combination of local criteria of different content, ensures the increase of solvency and profitability of the activities of the leading participants of the investment process, and the conditions for ensuring high liquidity of assets and projects and their social efficiency.

In order to create a reliable and scientifically sound picture of the investment cycle for the investor, a deterministic cost-asset-source model is developed, based on standard elements of network-determined work-arc models, but using a new parameter system. Parameters of the cost-assetsource model are subject to the requirements of ensuring liquidity, social efficiency, profitability and resource efficiency in accordance with the multifaceted basis of the previous model.

\section{SUMMARY}

The article provides an overview of theoretical prerequisites for developing economic and social appraisal system while forming a portfolio of construction investment projects. The author gives analysis of theoretical and practical approaches to the interpretation of the categories «liquidity», «liquidity of construction projects assets « «solvency», «solvency of the investor», prerequisites for the development of strategic aspects of the developer's future assets liquidity in combination with the efficiency of projects as a basis for reviewing the parametric framework for investment portfolio assessment. The article reviews theoretical and applied methods of project selection, such as discounting methods, integral indicators, project 
organizational and technological decision assessment, econometric models based on game theory, investment criteria balance, factor analysis, statistical consistency criteria of technological solutions and calendar optimization. The author defines investment priorities of building composition and structure of the investment portfolio which ensures the maximum possible efficiency of investments taking into account their liquidity requirements.

To provide the project investor (creditor) with a reliable and economically sound picture of the flow of project assets at different phases and elements of the investment cycle, an innovative model of multicriteria project assesment is proposed, which uses project liquidity indicators and solvency of organizations as a leading requirement (criterion). The methodological basis for the created model was system analysis, optimization models by several criteria and ways of their agreement.

The article considers one of the basic components of the proposed model - the model of matching the solvency of the investor with the assets liquidity of construction projects. In the future, this model is going to be supplemented by new developments, which will include the balance and structural method, and network models of «work-arc» with updated parameters as a basis for process formalization of investment cycle.

\section{REFERENCES}

1. Tetyana Marchuk, Dmytro Ryzhakov, Galyna Ryzhakova and Sergiy Stetsenko (2017). Identification of the basic elements of the innovationanalytical platform for energy efficiency in project financing. Investment Management and Financial Innovations Vol. 14(4), pp. 12-20.

2. Bielienkova O. Yu. Tendentsii rozvytku budivelnoi haluzi yak chynnyky formuvannia stratehichnoi konkurentospromozhnosti budivelnykh pidpryiemstv // Budivelne vyrobnytstvo. 2014. Vol. 57. P. 24-30.

3. Vakhovych I. V. Pidvyshchennia efektyvnosti upravlinnia biznesprotsesamy budivelnykh pidpryiemstv / I.V.Vakhovych : [tekst] // Budivelne vyrobnytstvo. - 2015. - № 59. - C. 3-6.

4. Zeltser R.Ia., Bielienkova O.Iu., Novak Ye., Dubinin D.V. tsyfrova transformatsiia protsesiv resursno-lohistychnoho ta orhanizatsiinostrukturnoho zabezpechennia budivnytstva. Nauka i innovatsii. 2019, № 5.

5. Tymoshenko O. V. Vyklyky ta zahrozy chetvertoi promyslovoi revoliutsii: naslidky dlia Ukrainy. Biznes Inform. - 2019. - № 2. - C. 21-29.

6. Izmailova Kateryna, Bielienkova Olga, Moholivets Anton. The essence of economic cycles and their impact on the financial stability of construction Nauk. pr. NDFI 2019; 2:139-150 
7. Bielienkova, O.Y. Tsifra, T.Y. and Shashko, M.M. (2010), «Implementation of international experience financing affordable housing through construction and savings banks in Ukraine», Problems systematic approach to the economy, vol. 3, available at: http://www.nbuv. gov.ua/ejournals/ PSPE/2010_3 /index.h.

8. Tytok V. V. Suchasnyi stan protsedury otrymannia zamovnykom budivnytstva dozvilnykh dokumentiv // Shliakhy pidvyshchennia efektyvnosti budivnytstva $\mathrm{v}$ umovakh formuvannia rynkovykh vidnosyn. 2012. Vol. 28. P. 142-150.

9. Sorokina L.V. Doslidzhennia ekonomichnykh vazheliv zabezpechennia rozvytku budivelnoi haluzi / L.V. Sorokina, A.F. Hoiko // Budivelne vyrobnytstvo. -2015 . - № 59. - C. 6-15.

10. Goiko A.F. Doslidzhennia zahroz investytsiinoi bezpeky budivelnykh pidpryiemstv. / L. V. Sorokina, A. F. Hoiko // Budivelne vyrobnytstvo. - 2016. - № 61. - S. 8-19.

11. Izmailova K.V. Vplyv nematerialnykh aktyviv, intelektualnoi skladovoi yikh vartosti, tekhnichnykh zasobiv IT, pidpryiemstva na tempy zrostanni chystoho dokhodu. Budivelne vyrobnytstvo 61/2, 2016. - S. 23-29.

12. Tsyfra T.Iu. Praktychnyi dosvid realizatsii mizhnarodnykh budivelnykh kontraktiv v Ukraini / T.Iu. Tsyfra // Budivelne vyrobnytstvo. 2017. - № 63/2 - S. 78-85.

13. Tsyfra T.Iu. Avansovi platezhi v mizhnarodnykh budivelnykh kontraktakh // Upravlinnia rozvytkom skladnykh system. - 2017. - 186-192.

14. Vplyv investytsiinoi aktyvnosti na obsiahy budivelnykh robit $\mathrm{v}$ Ukraini // O.Iu. Bielienkova / Shliakhy pidvyshchennia efektyvnosti budivnytstva $\mathrm{v}$ umovakh formuvannia rynkovykh vidnosyn.: $\mathrm{zb}$. naukovykh prats. - vyp.30. - 2013. - S. 17-26

15. Ivakhnenko I.S. Budivelnyi development yak instrument realizatsii derzhavnoi investytsiinoi polityky // Efektyvna ekonomika (elektronnyi zhurnal). - 2019. - № 1. - Rezhym dostupu: http://www.economy.nayka.com.ua/?op=1\&z

16. Lych. V.M. Proekty $\mathrm{v}$ haluzi infrastruktury: partnerstvo derzhavnoho ta pryvatnoho sektoriv: Monohrafiia. KNUBA. Vydannia 2-he, vypravlene ta dopovnene. - K.; SPD Pavlenko, 2017. - 320 s.

17. Dmytro Ryzhakov, Oksana Malykhina, Vadym Pokolenko, Chupryna Yurii. The identification of alternatives and changesin scenarios for the developmen to fregional build clusters //DmytroRyzhakov, OksanaMalykhina, VadymPokolenko, Chupryna Yurii // International Journal of Engineering \&Technology, Vol 7, No 4.8 (2018): Special Issue 8. 
18. Marchuk T., Ryzhakov D. Analysis of financing sources of projects development for Ukrainian enterprises // Zbirnyk naukovykh prats «Upravlinnia rozvytkom skladnykh system». - yp.. 31. - K.: KNUBA, 2017. - s. 166-170.

Information about the author: Stetsenko S. P., DSc in Economics, Associate Professor, Head of the Department of Construction Economics, Kyiv National University of Construction and Architecture 31, Povitroflotsky Ave., Kyiv, 03037, Ukraine 


\section{OPTIMIZATION OF CONSTRUCTIVE AND TECHNOLOGICAL SOLUTIONS OF HIGH-RISE ENGINEERING STRUCTURES EMERGENCY MEASURES}

\section{Menejljuk O. I.}

\section{INTRODUCTION}

There is a large number of high-rise engineering structures in Ukraine and abroad. Most of them are operated by ten years or more. Many high-rise engineering facilities require repair work, and some - emergently. Such projects require a significant investment. As a rule, there are many options for the upgrade. They may have different costs, deadlines. The specificity of some objects requires a specific schedule (only on the night shift, the use of a limited number of people or calendar time). The regulations and information sources have no guidance on the selection of effective organizational and technological decisions at reconstruction of such buildings.

The use of traditional building processes modeling methods makes it impossible to evaluate the effectiveness of variants of organizational and technological solutions. Modeling of these options and experimental analysis of statistical models will determine the best solution for the selected performance criteria.

\section{Analysis of information sources}

To solve the problem of optimizing the project emergency measures radio tower them. Shukhov was conducted numerical experiment on modeling options of organizational solutions to these works. When carrying out a numerical study used the theory of optimal experimental design, experimental and statistical modeling, advanced software for the construction of the calendar-network models construction industry ${ }^{1,2,3}$. The numerical study of the developed algorithm allows to reasonably choose the

\footnotetext{
${ }^{1}$ Вознесенский В.А. Статистические методы планирования эксперимента в техникоэкономических исследованиях / В.А. Вознесенский // М.: Финансы и статистика, 1981. 263 c. 7.

2 Адлер Ю.П. Планирование эксперимента при поиске оптимальных условий / Ю.П. Адлер, Е.В. Маркова, Ю.В. Грановский // М. : Наука. - 1-е изд., 1971. - 283 с. 2-е изд., 1976. - $279 \mathrm{c.}$

${ }^{3}$ Налимов В.В. Теория эксперимента. / В.В. Налимов // М. : Наука, 1971. - 208 с.
} 
optimal design and technological solutions for the complex restoration work in difficult conditions, with limited institutional financing ${ }^{4,5}$.

\section{The optimization algorithm design and technological solutions emergency measures}

Optimization tasks solution consists of the following steps:

Analysis of design estimates for the project emergency measures, which are the first of the planned phases of the restoration of the tower it. Shukhov; choice of design and technological design solution alternatives, the choice of optimization criteria and plan of numerical experiment;

bigger the calculation and construction of the calendar-network models of complex emergency measures in MS Project program in accordance with the selected plan of numerical experiment;

mathematical processing of the simulation results is constructivetechnological decisions of emergency measures;

selection of optimal design and technological parameters in accordance with the existing limitations in technology, organization and project financing emergency measures.

The study used estimates, reflecting actual costs of construction and installation works. Building renovation schedules can correctly display the sequence and adopted technological solutions during work at height. The technique allows a quantitative assessment of alternatives to structural and technological solutions with varying versions of the complex organization of emergency response work, financing conditions and existing restrictions.

Fig. 1 shows a block diagram of a research methodology for optimizing project emergency measures on the tower Shukhov.

After creating models (diagrams) of building production on the basis of approved plan of numerical experiment should build ES model complex emergency measures. The construction of ES model is to find the coefficients of a mathematical model that adequately describes the emergency project work within the prescribed limits of the factor space. ES model will build according to the most important indicators of the influencing factors, make their analysis, to investigate the optimum area according to selected criteria.

\footnotetext{
${ }^{4}$ Краковский Г.И. Планирование экспериментов / Г.И. Краковский, Г. Ф. Филаретов. // Минск: БТУ, 1982. - 757 с.

${ }^{5}$ Вознесенский В.А. Численные методы решения строительно-технологических задач на ЭВМ / В.А. Вознесенский, Т.В. Ляшенко, Б.Л. Огарков // К. : Вища школа, 1989.-328. с.
} 


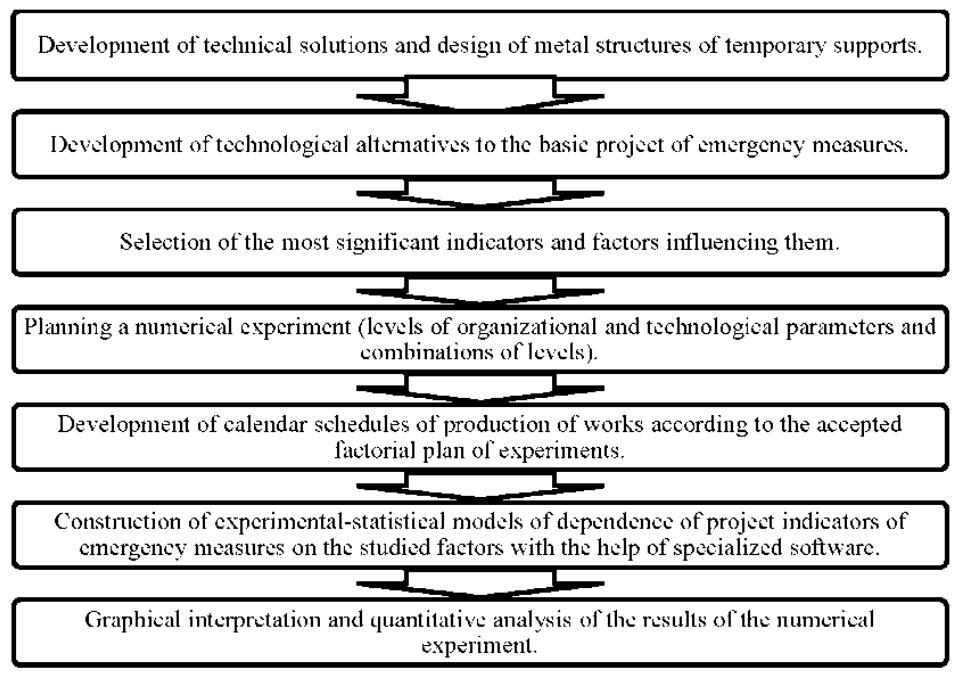

\section{Fig. 1. Block diagram of the research methodology for optimizing project emergency measures on the tower it. Shukhov}

Below is an algorithm analyzing the survey results.

1. Preliminary analysis of the most common patterns of the study by the analysis of the matrix (table) of experiment results.

2. Building a basic multidimensional graphs of performance of all the factors, their analysis and the search for areas of factor space, containing the optimum point.

3. The ranking factors in the degree of influence on the average values in the area factors.

4. Comparison of several points optimum for the selected criteria: organizational, technological, financial and others.

5. Construction of multi-dimensional charts and with the introduction of restrictions on the values of parameters and factors.

6. Construction of the final organizational and technological models of emergency measures taking into account the optimal solution and the required detail.

\section{The rationale for the plan to construct a numerical experiment ES model}

Emergency measures consist in the construction of temporary structures within the pillars of the tower it. Shukhov followed by «hanging» of the 
elements of the tower, which will reduce the load on the supporting structures of the emergency facilities. Subsequently temporary structures may be used as supports for the building production during reconstruction of the tower. After the reconstruction and implementation of the necessary measures for the preservation of cultural heritage object it is planned to dismantle the temporary supports.

Draft emergency measures includes the following work package:

dismantling works;

apparatus pile foundation and monolithic grillage for temporary supporting structures:

fabrication and installation of supports of metal structures;

«Hanging out» elements of the tower it. Shukhov;

priming and painting of steel structures.

The main work during the complex emergency response activities are the manufacture and installation of temporary support structures. The design documentation shows the device columns of temporary structures of hollow tube 1020 and a diameter of $720 \mathrm{~mm}$., Followed by their partial filling with concrete. The joints of tubular columns, as well as compounds in knots abutting columns, connections, spacers and consoles temporary supporting structures made welded. However, the device a large number of welded connections at a considerable height $(100 \mathrm{~m}$.) Is problematic. In this regard, it is accepted as an alternative technology to perform device columns flanged joints, bolted joints. To save money and human resources proposed to reduce the height of the steel columns filled with concrete.

The following indicators are taken as the most significant:

Duration mounting temporary supporting structures (Y1) - a period of works, comprising the assembly of metal columns, connections, struts, ladders and platforms, as well as the operation for filling the concrete columns.

The full cost of the project with charges (Y2) - the sum of direct costs and fixed costs on emergency measures. Direct costs are taken in accordance with the budget documentation, taking into account the estimated coefficients and the necessary charges. Fixed costs accepted by an expert estimation of 500 thousand. Rub. / Month.

The intensity of the funding for the project (Y3) - ratio of the total cost of the complex emergency measures to the full duration, expressed in months.

The factors most significantly influencing the specified indicators were adopted: 
Embodiments constructive and technological solutions devices temporary supporting structures (CTE):

1. device via welds temporary supporting structures in the form of hollow columns with subsequent filling with concrete to the level of $24.65 \mathrm{~m}$ - KTR1.;

2. the use of flanges at the device temporary supporting structures in the form of hollow columns filled with concrete to the level of $1.50 \mathrm{~m}$, provided an increase of the wall thickness of tubular members -. KTR2.

The degree of integration of elements mounted columns (X1) conventionally involves continuous changes in the degree of integration of elements within a weight member mounted from 1 to $10 \mathrm{~m}$ This corresponds to the minimum and maximum possible weight of elements in view of payload mechanisms work conditions of production and safety..

The number of workers employed in the installation of metal structures (X2) - adopted in the range of 5 to 15 people. The factor takes into account the possibility of setting one, two or three pulley service. The total number of work is divided into units in accordance with the presence pulley.

It should be noted that the factor «variants constructive and technological solutions temporary supporting structures» refers to a type of «value.» This means that the levels of this factor are discrete, they can not be described using a numerical scale. The levels of the factor identified as KRT1 and KRT2. Therefore plan comprises two series of experiments with single scale levels of indicators of units and X1 factors (degree of integration of elements mounted columns) and X2 (the number of workers employed in assembly of steel structures). These two series form two factorial subspace - for KTR1 and KTR2. The plan of this type will properly compare the results of two series of experimental studies in conventionally single factor space.

The experimental design using the factors given above, is shown in table 1.

\section{Prerequisites for the calculation}

To determine the correct values of labor and cost estimate documentation was used in the production of works. According to the results of its analysis with a special MS Excel Tool - «pivot tables» - was composed table 2 Containing a bigger range of works, their estimated complexity and cost. In drawing up the estimates are generally used basic prices, for example, 2001. Inflation, location of the facility and other charges are taken into account only when determining the final amount.

Therefore, in the above amounts (Table. 2) Conventionally adopted the same for all work transfer coefficient taking into account the above 
calculation. The coefficient was calculated by dividing the total estimated cost calculated on the amount of direct costs.

Table 1

\section{Experimental Design}

\begin{tabular}{|c|c|c|c|c|}
\hline \multirow{2}{*}{ 离 } & \multicolumn{2}{|c|}{$\begin{array}{l}\text { The degree of pre-assembly mounted } \\
\text { element } M \text { / K columns }\left(X_{1}\right) \% \text {. }\end{array}$} & \multicolumn{2}{|c|}{$\begin{array}{l}\text { The number of workers employed in } \\
\text { the installation of } \mathrm{M} / \mathrm{K}\left(\mathrm{X}_{2}\right) \text {, pers. }\end{array}$} \\
\hline & normalized values & actual values & normalized values & actual values \\
\hline \multicolumn{5}{|c|}{ Structural and technological solutions №1- KTR1 } \\
\hline 1.1 & -1 & $0 \%$ & -1 & 5 \\
\hline 1.2 & 0 & $50 \%$ & -1 & 5 \\
\hline 1.3 & +1 & $100 \%$ & -1 & 5 \\
\hline 1.4 & -1 & $0 \%$ & 0 & 10 \\
\hline 1.5 & 0 & $50 \%$ & 0 & 10 \\
\hline 1.6 & +1 & $100 \%$ & 0 & 10 \\
\hline 1.7 & -1 & $0 \%$ & +1 & 15 \\
\hline 1.8 & 0 & $50 \%$ & +1 & 15 \\
\hline 1.9 & +1 & $100 \%$ & +1 & 15 \\
\hline \multicolumn{5}{|c|}{ Structurally-technological solution №2 - KTR2 } \\
\hline 2.1 & -1 & $0 \%$ & -1 & 5 \\
\hline 2.2 & 0 & $50 \%$ & -1 & 5 \\
\hline 2.3 & +1 & $100 \%$ & -1 & 5 \\
\hline 2.4 & -1 & $0 \%$ & 0 & 10 \\
\hline 2.5 & 0 & $50 \%$ & 0 & 10 \\
\hline 2.6 & +1 & $100 \%$ & 0 & 10 \\
\hline 2.7 & -1 & $0 \%$ & +1 & 15 \\
\hline 2.8 & 0 & $50 \%$ & +1 & 15 \\
\hline 2.9 & +1 & $100 \%$ & +1 & 15 \\
\hline
\end{tabular}

In the analysis of table 2 it is clear that the estimated cost of works on manufacturing and installation of metal columns vary depending on the type of CTE. The change in the cost due to the fact that the manufacture and installation of steel structures bolted to consider the cost of flanges, bolts, nuts and washers.

For correct charting construction Erection of columns, connections, spacers, stairs and platforms were divided into separate processes, appropriate technology zahvatki. Separately allocated processes preassembly and assembly of steel structures of columns, since these processes are the direct object of the optimization of the study. When constructing schedules an object was divided into four technology tiers:

1. elevations in 0.00: $24.65 \mathrm{~m}$;

2. in elevation 24.65: $46.40 \mathrm{~m}$;

3. in elevation 46.40: $73.10 \mathrm{~m}$;

4. in elevation 73.10: $98.10 \mathrm{~m}$. 
Table 2

Analysis of labor input and cost estimates

\begin{tabular}{|c|c|c|c|c|}
\hline \multirow[t]{2}{*}{ titles of works } & \multicolumn{2}{|c|}{$\begin{array}{l}\text { Labor costs, } \\
\text { man-hours. }\end{array}$} & \multicolumn{2}{|c|}{ Costs by a factor rubles. } \\
\hline & KTR2 & KTR1 & KTR2 & KTR1 \\
\hline Disassembly & 4987.85 & 4987.85 & 29193876.81 & 29193876.81 \\
\hline $\begin{array}{l}\text { Helicopter dismantling } \\
\text { 7th Section }\end{array}$ & 378 & 378 & 26325451.04 & 26325451.04 \\
\hline $\begin{array}{c}\text { Removal of metal staircase and } \\
\text { platforms }\end{array}$ & 1260,00 & 1260,00 & 767299.56 & 767299.56 \\
\hline Dismantling of freight elevator & 1602,00 & 1602,00 & 160483.37 & 160483.37 \\
\hline dismantling of foundations & 1664.96 & 1664.96 & 1809138.96 & 1809138.96 \\
\hline Debris removal & 82.89 & 82.89 & 131503.87 & 131503.87 \\
\hline $\begin{array}{c}\begin{array}{c}\text { Apparatus pile foundation, } \\
\text { concrete }\end{array} \\
\end{array}$ & 1676.99 & 3934.44 & 3857162.55 & 7745534.01 \\
\hline CFA piling apparatus & 1286.33 & 1286.33 & 2861624.22 & 2861624.22 \\
\hline Apparatus monolithic grillage & 253.72 & 253.72 & 759675.24 & 759675.24 \\
\hline $\begin{array}{l}\text { Concreting of columns } \\
\text { supporting structures }\end{array}$ & 136.93 & 2394.39 & 235863.09 & 4124234.55 \\
\hline Metal Fabrication & 35543,00 & 33739,00 & 37316007.30 & 34244250.46 \\
\hline Production M / K Gain & 32243,00 & 30439,00 & 34191773.19 & 31120016.36 \\
\hline $\begin{array}{l}\text { Production M / K ladders and } \\
\text { platforms }\end{array}$ & 3300,00 & 3300,00 & 3124234.11 & 3124234.11 \\
\hline installation of metal structures & 24988.28 & 24988.28 & 18573914.60 & 17502538.62 \\
\hline $\begin{array}{l}\text { Fitting mounting devices } \\
\text { and guards }\end{array}$ & 1281,00 & 1281,00 & 337750.02 & 337750.02 \\
\hline Installation of M / K columns & 4537.53 & 4537.53 & 5970942.92 & 4899566.94 \\
\hline $\begin{array}{c}\text { Installation of } \mathrm{M} / \mathrm{K} \text { ties and } \\
\text { braces }\end{array}$ & 5936.53 & 5936.53 & 4625307.16 & 4625307.16 \\
\hline $\begin{array}{l}\text { Installation of } \mathrm{M} / \mathrm{R} \text { ladders } \\
\text { and platforms }\end{array}$ & 4046.22 & 4046.22 & 2955998.34 & 2955998.34 \\
\hline «Hanging out» elements of tower & 9187,00 & 9187,00 & 4683916.17 & 4683916.17 \\
\hline Corrosion protection of metal & 9149,00 & 9149,00 & 2911680.68 & 2911680.68 \\
\hline $\begin{array}{c}\text { Installation and removal of } \\
\text { construction equipment }\end{array}$ & 8350,00 & 8350,00 & 1582260.07 & 1582260.07 \\
\hline $\begin{array}{l}\text { Cleaning brushes metal } \\
\text { structures }\end{array}$ & 605 & 605 & 130900.29 & 130900.29 \\
\hline $\begin{array}{l}\text { Prime-coating of metal } \\
\text { constructions }\end{array}$ & 32 & 32 & 32365.87 & 32365.87 \\
\hline Coatings & 162 & 162 & 1166154.45 & 1166154.45 \\
\hline The overall result & 76345.12 & 76798.58 & 91852641.94 & 91597880.59 \\
\hline
\end{tabular}

Linking works in all charts was performed taking into account the mainstreaming of work: while one team of installers performs high-altitude installation spacers and consoles, the second performs pre-assembly of columns for the next tier, installation of ladders and platforms on the lower tier. Safety production work in this case is provided by the mutual displacement of teams in the horizontal plane. Analysis performed graphs 
showed that the pre-assembly process columns, installation of stairs and platforms are not on the critical path. To select options for execution of works was drawn up a list of process steps for the construction of columns of temporary structures for various structural and technological solutions. It is indicated intable 3 . The table contains the distribution of resources between cost manufacturing operations at constructive and technological solutions №1 and №2 and different levels of factor $\mathrm{X}_{1}$. This allocation is made on the results of expert evaluation. It should be noted that the operations for assembly and installation of consolidated elements of columns (rows 1 and 5Table. 3) Have different resource allocation costs for two types of constructive and technological solutions elements of metal constructions. With the help of factors taken into account the difference in the amount of labor and cost.

At table 3 allocated different levels of factor $X_{1}$, as shown in the respective columns (columns 2, 3 and 4). Note that the resource costs for transporting and installing the different elements of metal constructions columns (rows 2, 3, 4 and 6 Table. 3). The difference is due to changes in the production process. Analysis coefficients shows they are inversely proportional to the degree of integration of mounted element.

Line 7 table 3 represents the sum of the coefficients of each mounting operation. Thus obtained final correction coefficient. It is used to adjust the values of labor and cash costs, which were subsequently made to the work of production schedules. For convenience, the correction factors are shown separately for works on pre-assembly and assembly of the elements in the design position (lines 8, 9 table 3 ).

\section{Results of experimental statistical modeling}

In this section, The analysis of the results of research on the optimization of the project emergency measures on the tower Shukhov. The object of this study is the optimization process of erecting temporary supporting structures. Their purpose - to support emergency facility before and during the work on the upgrade. Optimization of design and technological solutions aimed at accelerating the process of reduction in price and construction of temporary structures and their dismantling after the restoration of the main structures of the tower.

In order to optimize the project emergency work was carried out experimentally-statistical simulation of the construction of temporary supports. The following parameters were investigated in the modeling process:

duration mounting temporary supporting structures $\left(\mathrm{Y}_{1}\right)$;

total project costs with charges $\left(\mathrm{Y}_{2}\right)$;

the intensity of the funding for the project $\left(\mathrm{Y}_{3}\right)$. 
On the figures shown above are the most affected by the following factors:

Table 3

\section{Coefficients resource allocation costs of technological operations} and correction coefficients depending on the degree of pre-assembly

\begin{tabular}{|c|c|c|c|}
\hline $\begin{array}{c}\text { Technological } \\
\text { operation designation }\end{array}$ & $\begin{array}{c}\text { The coefficient of } \\
\text { installing } M / K \\
\text { without } \\
\text { preassembly } \\
\text { (conventional } \\
\text { element weight } \\
1 \text { ton) }\end{array}$ & $\begin{array}{l}\text { The coefficient of } \\
\text { installing } \mathrm{M} / \mathrm{K} \\
\text { with a degree of } \\
\text { pre-assembly } 50 \% \\
\text { (conditional } \\
\text { weight element } \\
5 \mathrm{~m} \text { ) }\end{array}$ & $\begin{array}{c}\text { The coefficient of } \\
\text { installing } M / K \\
\text { with a degree of } \\
\text { pre-assembly } \\
100 \% \\
\text { (conventional } \\
\text { element weight } \\
10 \text { tons) }\end{array}$ \\
\hline $\begin{array}{c}\text { Pre-assembly mounted } \\
\text { element M / K (at } \\
\text { KTR1 / KTR2) }\end{array}$ & $0 / 0$ & $0.52 / 0.346$ & $0.585 / 0.39$ \\
\hline $\begin{array}{l}\text { Installation of the } \\
\text { lifting devices }\end{array}$ & 0,025 & 0,005 & 0.0025 \\
\hline $\begin{array}{c}\text { Hoisting element } \mathrm{M} / \\
\mathrm{K} \text { to the installation } \\
\text { site }\end{array}$ & 0.1 & 0.02 & 0.01 \\
\hline $\begin{array}{l}\text { Installation and } \\
\text { alignment of the } \\
\text { mounted element }\end{array}$ & 0.2 & 0.04 & 0.02 \\
\hline $\begin{array}{c}\text { Installation in design } \\
\text { position (at KTR1 / } \\
\text { KTR2) }\end{array}$ & $0.65 / 0.433$ & $0.13 / 0.086$ & $0.065 / 0.043$ \\
\hline Removing slinging & 0,025 & 0,005 & 0.0025 \\
\hline $\begin{array}{c}\text { Total correction } \\
\text { factor }\end{array}$ & $1 / 0,783$ & $0.72 / 0.502$ & $0.685 / 0.468$ \\
\hline $\begin{array}{c}\text { including } \\
\text { in the pre-assembly }\end{array}$ & $0 / 0$ & $0.52 / 0.346$ & $0.585 / 0.39$ \\
\hline $\begin{array}{c}\text { including } \\
\text { transportation to the } \\
\text { installation site and } \\
\text { the installation in } \\
\text { design position }\end{array}$ & $1 / 0,783$ & $0.2 / 0.156$ & $0.1 / 0.078$ \\
\hline
\end{tabular}

variants of constructive and technological solutions devices temporary supporting structures (KTR1 or KTR2);

the degree of integration of elements mounted columns $\left(\mathrm{X}_{1}\right)$;

the number of workers employed in the installation of metal structures $\left(\mathrm{X}_{2}\right)$.

the experimental results shown in the matrix table 4. It shows the values of parameters at different points of the space factor, and varying levels of factors, for which the corresponding values of the indicators were obtained. 
Table 4

Matrix of research results

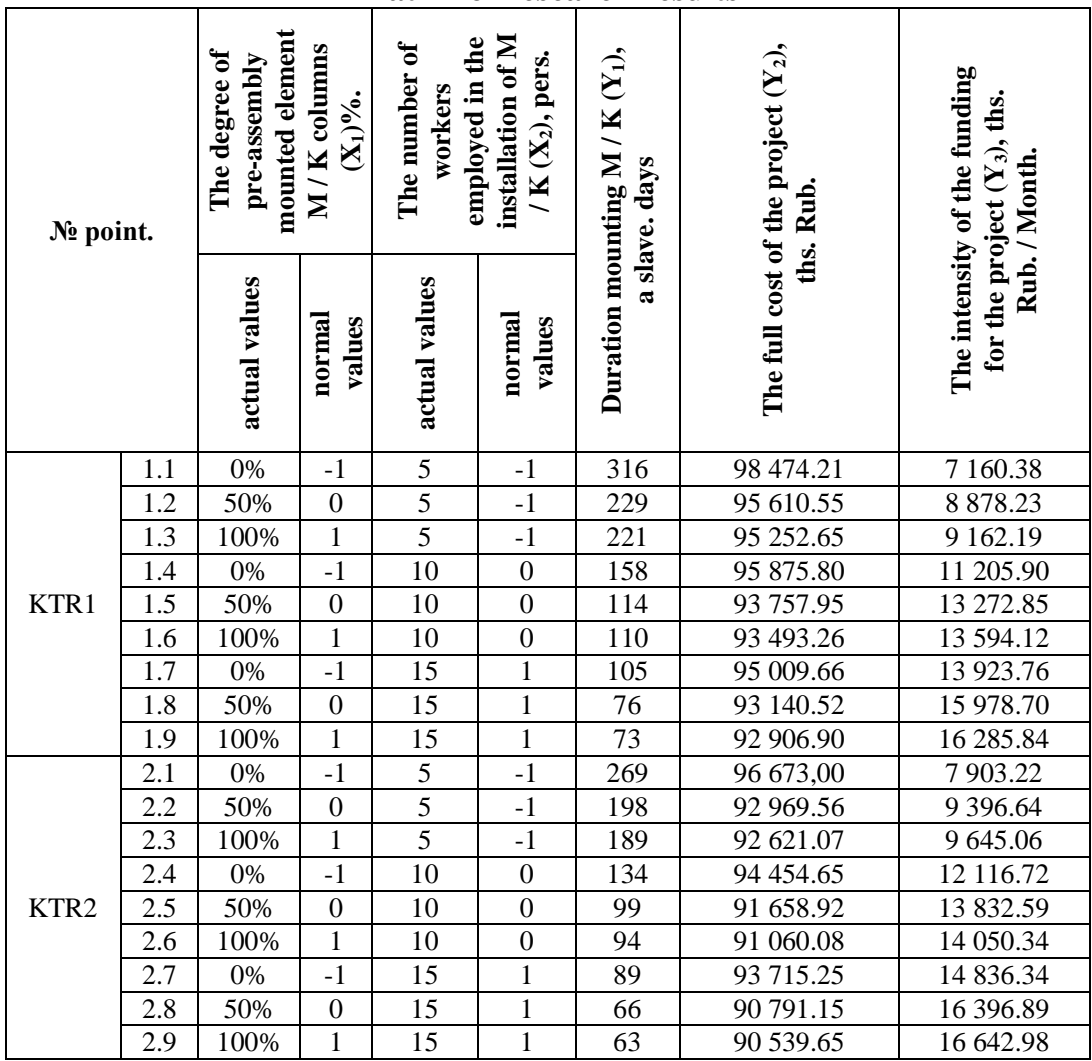

Let us analyze table 4 . Note that the figures «prolonged erection of temporary supporting structures» and «full cost of implementing the project with charges» have somewhat lower values at KTR2. This observation is true in all areas of the factor space. For the values of the indicator «intensity of project financing» change factor level «versions structural and technological solutions» does not have a significant impact.

Formula 1 and 2 Electric models are index «duration temporary supporting structures mounted» in analytical form (with and KTR2 KTR1). On Figure 2 these models are presented in graphical form.

$Y_{1}^{\mathrm{KTP} 1}=\operatorname{EXP}\left(4,744-0,179 x_{1}+0,14 x_{1}^{2}+\bullet-0,549 x_{2}+0,144 x_{2}^{2}\right) ;(1)$ 


$$
\begin{gathered}
Y_{1}^{\mathrm{KTP} 2}=\operatorname{EXP}\left(4,593-0,167 x_{1}+0,138 x_{1}^{2}+\right. \\
\left.+0,012 x_{1} x_{2}-0,541 x_{2}+0,152 x_{2}^{2}\right)
\end{gathered}
$$

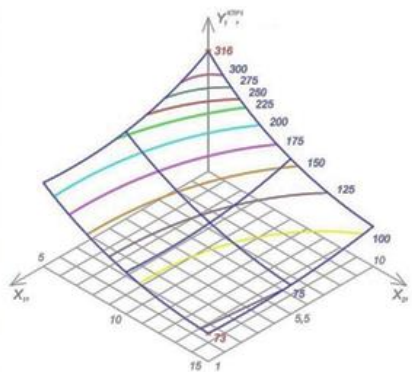

Structurally-technological solution № 1 (KTR1)

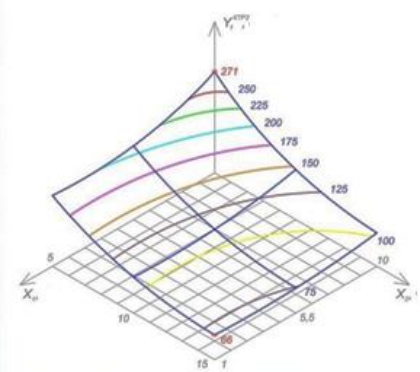

Structurally-technological solution № 2 (KTR2)

Fig. 2. Laws of the indicator «duration temporary supporting structures mounted» when different constructive variants, technological solutions temporaries columns

Formula 3 and 4 ES models are the indicator «total project costs with charges» in the closed form (at KTR1 and KTR2). On Figure 3 these models are presented in graphical form.

$$
\begin{gathered}
Y_{2}^{\mathrm{KTP} 1}=\operatorname{EXP}\left(11,449-0,012 x_{1}+0,009 x_{1}^{2}+\bullet-0,013 x_{2}\right. \\
\left.\quad+0,006 x_{2}^{2}\right) ; \\
Y_{2}^{\mathrm{KTP} 2}=\operatorname{EXP}\left(11,424-0,019 x_{1}+0,015 x_{1}^{2}+0,002 x_{1} x_{2}\right. \\
\left.-0,013 x_{2}+0,005 x_{2}^{2}\right) ;
\end{gathered}
$$

Formula 5 and 6 ES models are the indicator «intensity of financing for the project» in an analytical form (if KTR1 and KTR2). On Figure 4 these models are presented in graphical form.

$$
\begin{gathered}
Y_{3}^{\mathrm{KTP} 1}=E X P\left(9,494+0,1 x_{1}-0,075 x_{1}^{2}-0,022 x_{1} x_{2}+0,305 x_{2}\right. \\
\left.-0,11 x_{2}^{2}\right) ; \\
Y_{3}^{\mathrm{KTP} 2}=\operatorname{EXP}\left(\begin{array}{c}
9,535+0,077 x_{1}-0,058 x_{1}^{2}-0,021 x_{1} x_{2} \\
\left.+0,289 x_{2}-0,108 x_{2}^{2}\right) ;
\end{array}\right.
\end{gathered}
$$


Analysis Fig. 2 shows that the variation index $Y_{1}$ «duration mounting temporary supporting structures» is slightly different depending on the adopted embodiment CTE. Both in one and in another case the minimum value of the factor levels $\left(\mathrm{X}_{1}=1 \mathrm{X}_{2}=5\right.$ pers. $)$ Correspond to the maximum value of the index $Y_{1 \text { max }}^{\mathrm{KTP} 1}=316,0$ days. $Y_{1 \text { max }}^{\mathrm{KTP} 2}=271,2$ day. At levels $\left(\mathrm{X}_{1}=1 ; \mathrm{X}_{2}=15\right.$ persons $)$ modeling showed a minimum value of the index $Y_{1 \text { min }}^{\mathrm{KTP} 1}=73,7$ day. The minimum index in the case in point is KTR2 $Y_{1 \min }^{\mathrm{KTP2}}=65,8$ day $\left(\mathrm{X}_{1}=10 \mathrm{~m}\right.$.; $\mathrm{X}_{2}=15$ pers. $)$.

According to the analysis Fig. 3 it can be concluded that the behavior of the index $\mathrm{Y}_{2}$ «total project costs with charges» slightly varies depending on the type of CTE columns. In both types the maximum index point is at coordinates $\left(\mathrm{X}_{1}=1 \mathrm{X}_{2}=\mathrm{T}\right.$.; 5 pers.) (Th. Rub .; thousand. Rub.). Minimum points coincide coordinates $\left(\mathrm{X}_{1}=10 \mathrm{~m}\right.$.; $\mathrm{X}_{2}=15$ pers.): Th. Rub .; thousand roubles. There is a difference in the index values of different factorial subspace (with KTR1 and KTR2). $Y_{2 \max }^{\mathrm{KTP} 1}=97635,84 Y_{2 \max }^{\mathrm{KTP2}}=$ $96567,73 Y_{2 \mathrm{~min}}^{\mathrm{KTP} 1}=92874,09 Y_{2 \mathrm{~min}}^{\mathrm{KTP} 2}=90581,02$

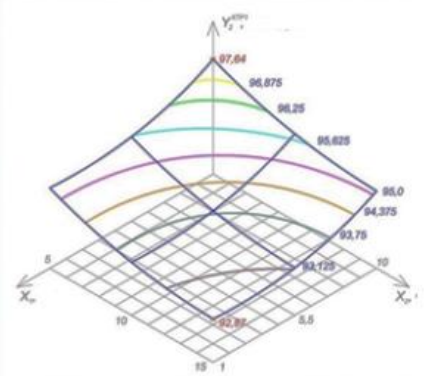

Structurally-technological solution № 1 (KTR1)

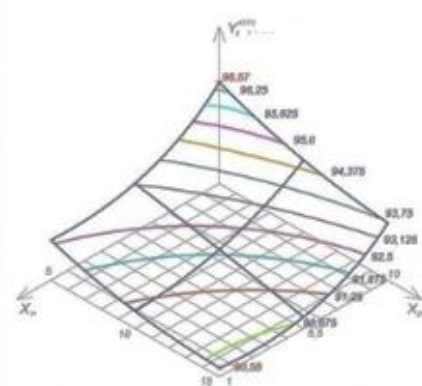

Structurally-technological solution № 2 (KTR2)

Fig. 3. Laws of change of the indicator «total project costs with charges» when using different options for structural and technological solution of temporary structures columns

It is due to both a decrease in direct costs, and a decrease in fixed costs for the whole project in the case of KTR2. In general, the use KTR2 saves 1.1 to 2.3 Mill. Rubles with various combinations of other factors.

Let us analyze Figure 4. On it show the indicator «the intensity of the funding for the project» for different types of steel structures CTE. The nature of the indicator is slightly different in different subspaces factor.

The coordinates of the minimum and maximum indicator and coincide when KTR1 KTR2. So, ths. Rub. / Month. ( $\mathrm{X}_{1}=10 \mathrm{~m}$.; $\mathrm{X}_{2}=15$ persons). 
thousand. rub. / month. ( $\mathrm{X}_{1}=1 \mathrm{X}_{2}=\mathrm{T}$;; 5 persons). thousand. rub. / month. $\left(\mathrm{X}_{1}=10 \mathrm{~m}\right.$.; $\mathrm{X}_{2}=15$ persons $)$. thousand. rub. / month. $\left(\mathrm{X}_{1}=1 \mathrm{X}_{2}=\mathrm{T}\right.$.; 5 pers.).

$$
\begin{aligned}
Y_{3 \mathrm{max}}^{\mathrm{KTP} 1} & =16187,58 Y_{3 \mathrm{~min}}^{\mathrm{KTP} 1}=7201,17 Y_{3 \mathrm{max}}^{\mathrm{KTP} 2}= \\
& =16547,66 Y_{3 \mathrm{~min}}^{\mathrm{KTP} 2}=7958,53
\end{aligned}
$$

On Figure 5 ranking diagram showing degrees of influence factors $\mathrm{X} 1$ and X2 on the studied parameters. The diagrams are constructed for different factorial subspace (KTR1 and KTR2). Note that in figures «duration temporary supporting structures mounted» $\left(\mathrm{Y}_{1}\right)$ and the «intensity of project funding» $\left(\mathrm{Y}_{3}\right)$ the degree of influence factors $\mathrm{X}_{1}$ and $\mathrm{X}_{2}$ varies slightly when moving CTE embodiment. For the record, «the full cost of the project with charges» $\left(\mathrm{Y}_{2}\right)$ the degree of influence of different factors: the KTR1 has great influence factor $\mathrm{X}_{2}$, at KTR2 - $\mathrm{H} 1$.

Figures 6-8 allows us to compare the behavior of the parameters depending on the level of factor $\mathrm{X}_{1}$ (the degree of integration of elements mounted columns). In this case $X_{2}$ factor (number of workers employed in assembly of steel structures) is fixed at one of three levels: 1, 0, 1 (5, 10 and 15 work respectively).

In the figure, graphics performance changes in different constructive variants, technological solutions are combined in a single chart.

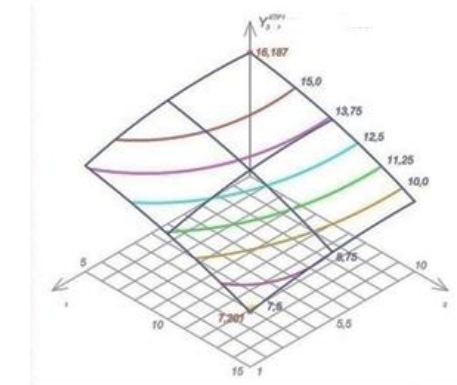

Structurally-technological solution № 1 (KTR1)

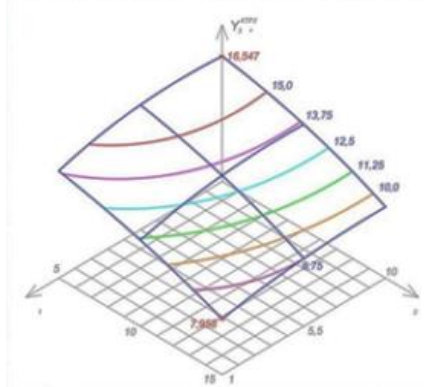

Structurally-technological solution № 2 (KTR2)

Fig. 4. Laws of change of the indicator «intensity of financing for the project» using different variants of constructive and technological solutions temporaries columns 


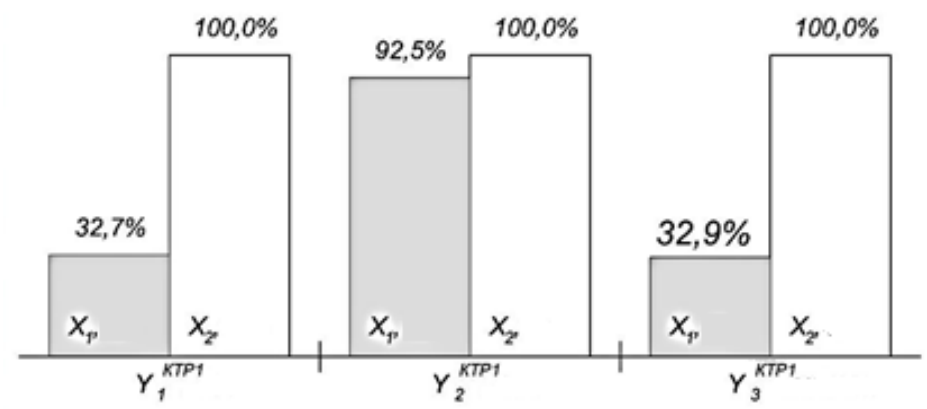

Structurally-technological solution № 1 (KTR1)

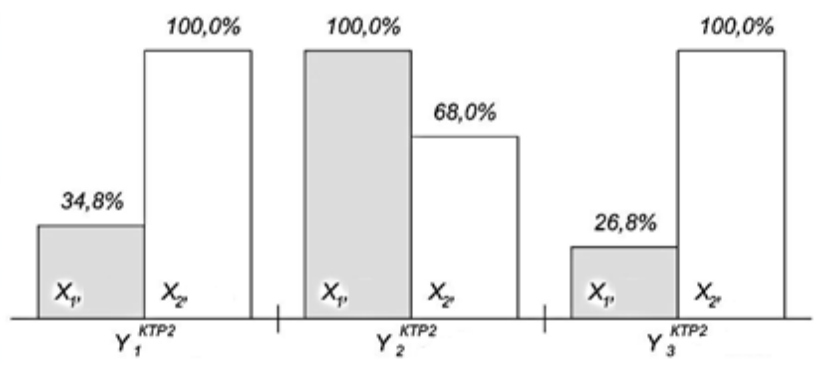

Structurally-technological solution №2 (KTR2)

Fig. 5. Ranking the degree of influence of factors $X_{1}$ and $X_{2}$ on the studied parameters using the different options of temporary structures CTE columns

In the analysis of Fig. 6 it is clear that the behavior of the index $\mathrm{Y}_{1}$ (time duration bearing designs of installation) under the influence of factor $X_{1}$ is different. It depends on the level of factor $\mathrm{X}_{2}$. The difference between the extreme values of the response function at $X_{2}=5$ people. It is as follows: 95.1 days for KTR1; 81.6 days for KTR2.

When $\mathrm{X}_{2}=-1$, this difference amounts to 31.7 and 23.9 days, respectively. $X_{1}$ factor affects the rate considerably less than a factor $X_{2}$, and can change it to 1.36-1.43 times (for different subspaces factor). 


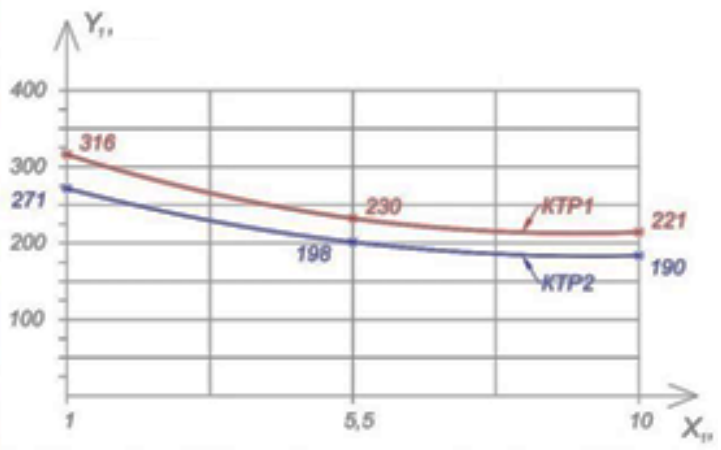

$X_{2}=5$ persons .

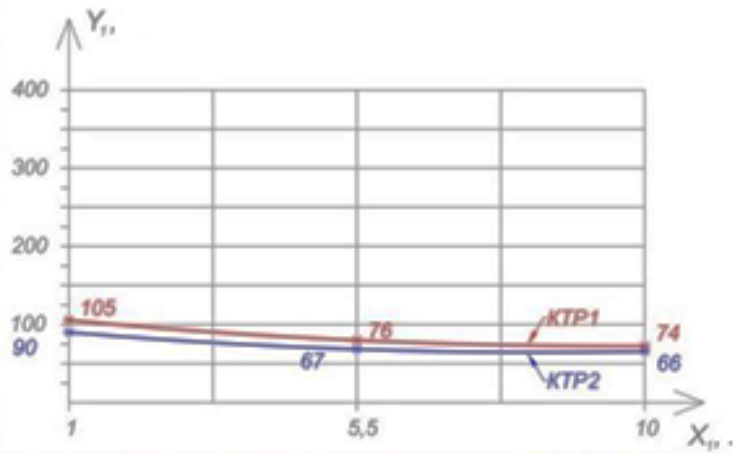

$X_{2}=10$ persons .

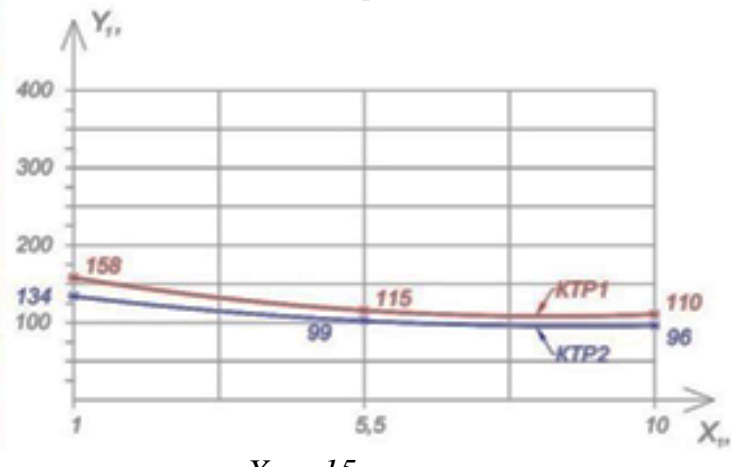

$X_{2}=15$ persons.

Fig. 6. Duration mounting temporary supporting structures $\left(Y_{1}\right)$ when changing the factor $X_{1}$ and $X_{2}$ fixation at levels of 5, 10,15 people for different constructive-technological decisions of temporary structures 
Let us analyze Figure 7. Change in $\mathrm{Y}_{2}$ (total project costs with charges), depending on the level of factor $X_{1} 2255,9-3971,9$ thousand. Rub., Which corresponds to $2,4-4,3 \%$ of the total costs. Such a small change in the index (in relative terms) is obviously due to the small proportion of fixed costs as a part of the total cost of the project emergency measures.

Consider Figure 8. Note that the behavior of the index $\mathrm{Y}_{3}$ (the intensity of the funding for the project) slightly varies when changing the structural and technological solutions metalwork columns.

The nature of changes in the rate under the influence of the factor $X_{1}$ is unchanged in all areas of the factor space. In general, the influence parameter on the factor $\mathrm{X} 1$ is small and the change is equal to $16-27 \%$ response at various levels of Factor $\mathrm{X}_{2}$.

Figures 9-11 allow us to compare the behavior of the parameters depending on the level of factor $\mathrm{X}_{2}$ (number of workers employed in the installation of steel structures). The level of factor $X_{1}$ (degree of integration of mounted elements of columns) is fixed at one of three levels: $-1,0,1$ (1, 5.5 and $10 \mathrm{~m}$, respectively.).

The figure below plots changes in the indices for different CTE combined in a single diagram.

Consider Figure 9. On it shows the change indicator «duration temporary supporting structures mounted» in various subspaces factor (at different CTE). Note that the variation index under the influence of the factor depends on the $\mathrm{X}_{1} \mathrm{X}_{2}$ factor level. Thus, the difference between the minimum and maximum index value in the area $X_{1}=1 \mathrm{t}$. Of 210.6 days to 181.5 days and KTR1 for KTR2. At the same time in the area $X_{1}=10 \mathrm{~m}$. This difference is 147.3 days and 123.8 days, respectively.

In general, the influence parameter on the factor $\mathrm{X}_{2}$, and significantly change its level can change values in response 2.88-3.02 times for different subspaces factor. 


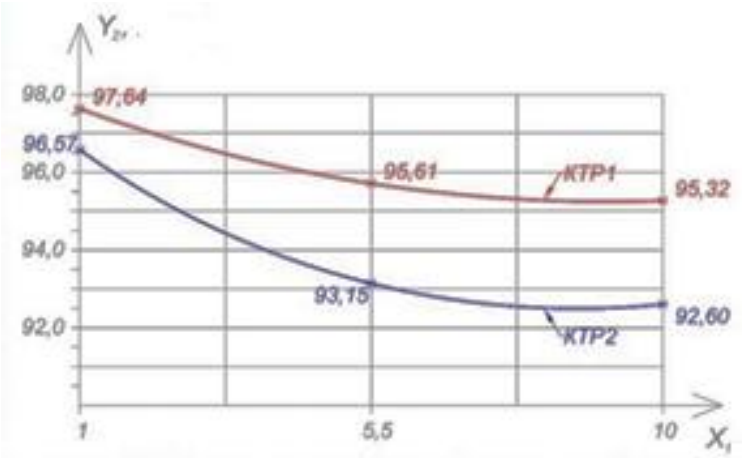

$X_{2}=5$ persons .

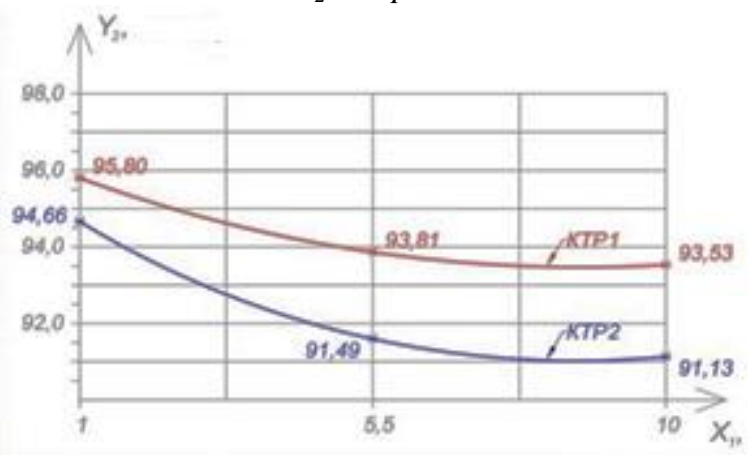

$X_{2}=10$ persons.

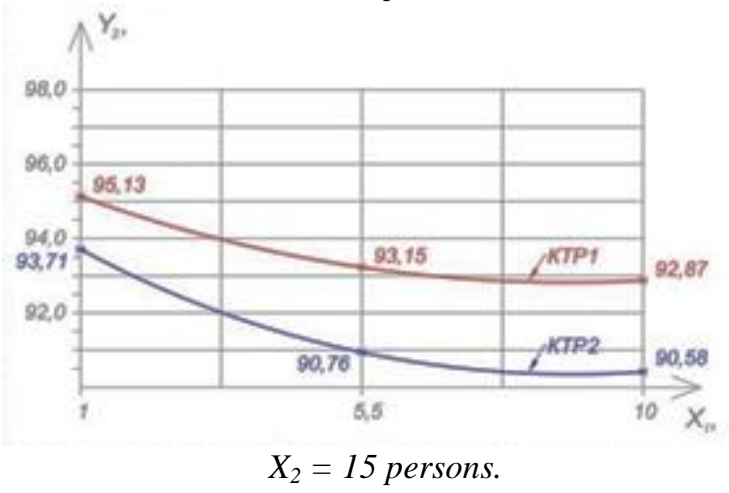

Fig. 7. The total cost for the project with charges $\left(Y_{2}\right)$ when changing the factor $X_{1}$ and $X_{2}$ fixation at levels of $5,10,15$ people for different constructive-technological decisions of temporary structures 


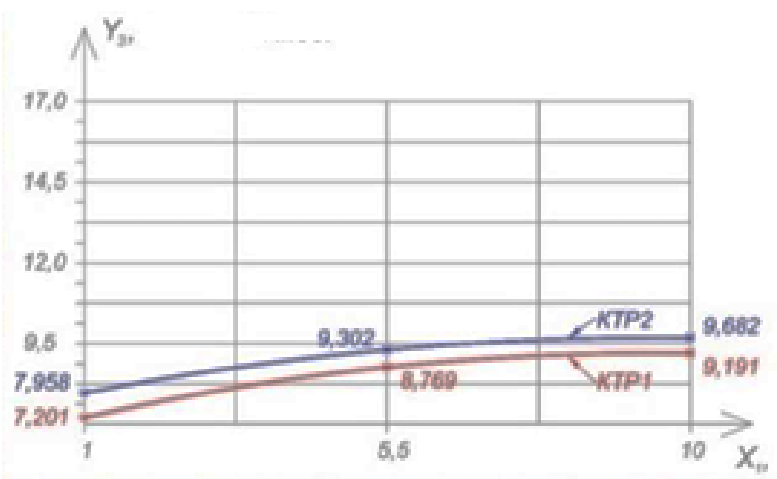

$X_{2}=5$ persons

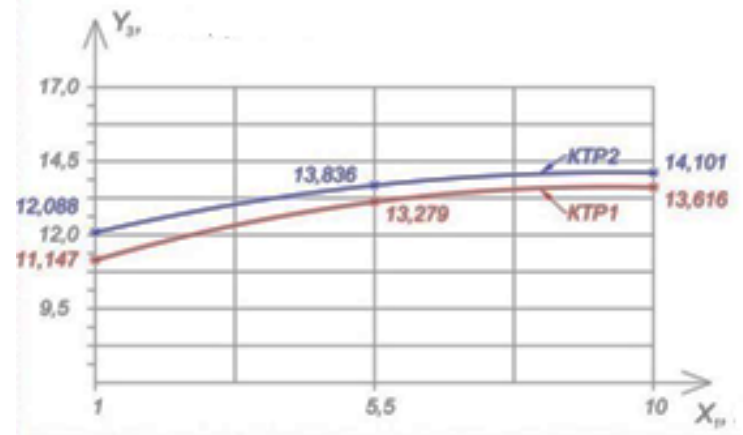

$X_{2}=10$ people

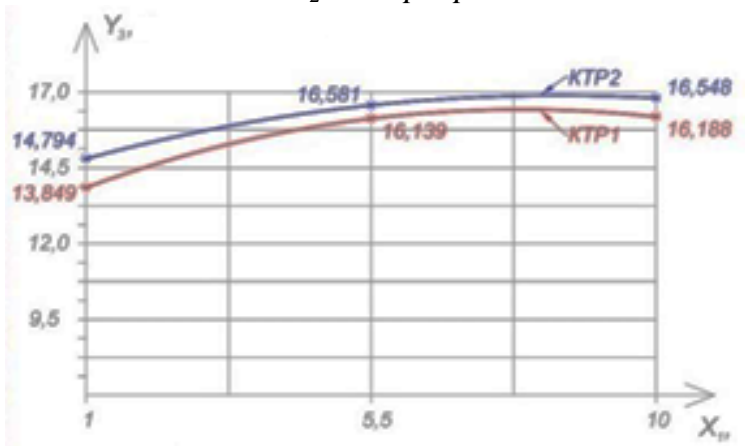

$X_{2}=15$ people

Fig. 8. The intensity of the funding for the project $\left(\mathrm{Y}_{3}\right)$ when changing the factor $X_{1}$ and $X_{2}$ fixation at levels of 5, 10, 15 people for different constructive-technological decisions of temporary structures 

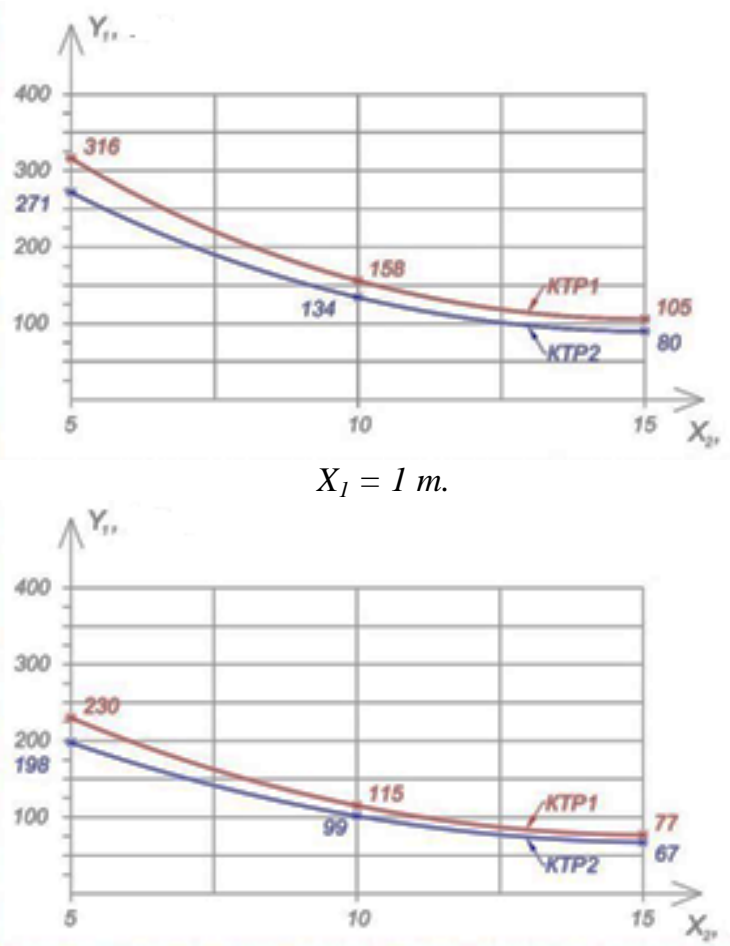

$X_{1}=5.5 t$.

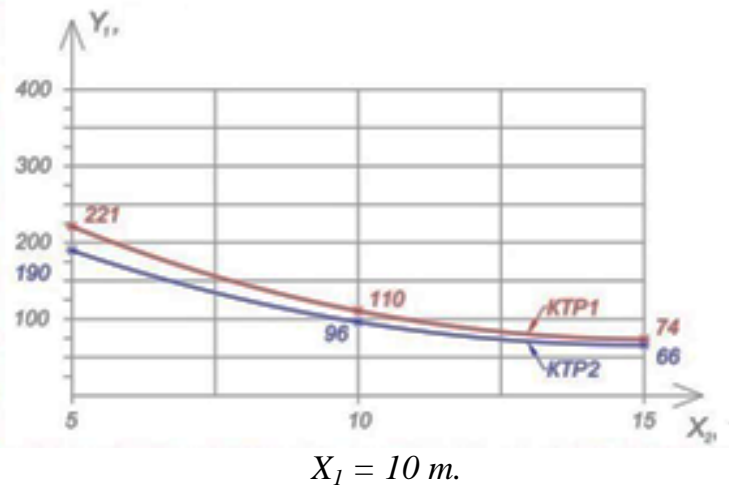

Fig. 9. Duration temporary supporting structures installation $\left(\mathbf{Y}_{1}\right)$ when changing the factor $X_{2}$ and $X_{1}$ fixation at levels $1,5.5,10 \mathrm{t}$. for different constructive and technological solutions temporaries 
In the analysis of Fig. 10 shows that increasing the level $\mathrm{X}_{2}$ slightly reduces the response value $-2 \%-$ as when using KTR1, KTR2 well. Compared with the effect of this change $X_{1}$ factor decreasing by $1-2 \%$, therefore, we can say that the factor X1 is somewhat greater influence on the index than $\mathrm{X}_{2}$ factor. The nature of changes in the rate is almost the same for all values of $X_{1}$.

Analysis figure 11 shows that the value of the index $\mathrm{Y}_{3}$ slightly different options for the building, designated as a constructive-technological decisions of temporary structures columns №1 and №2.

Also immaterial nature of the effect varies from $X_{2}$ to measure depending on the level $X_{1}$. The change indicator based on the level $X_{1}$ is 1,7-1,92 times for different subspaces factor.
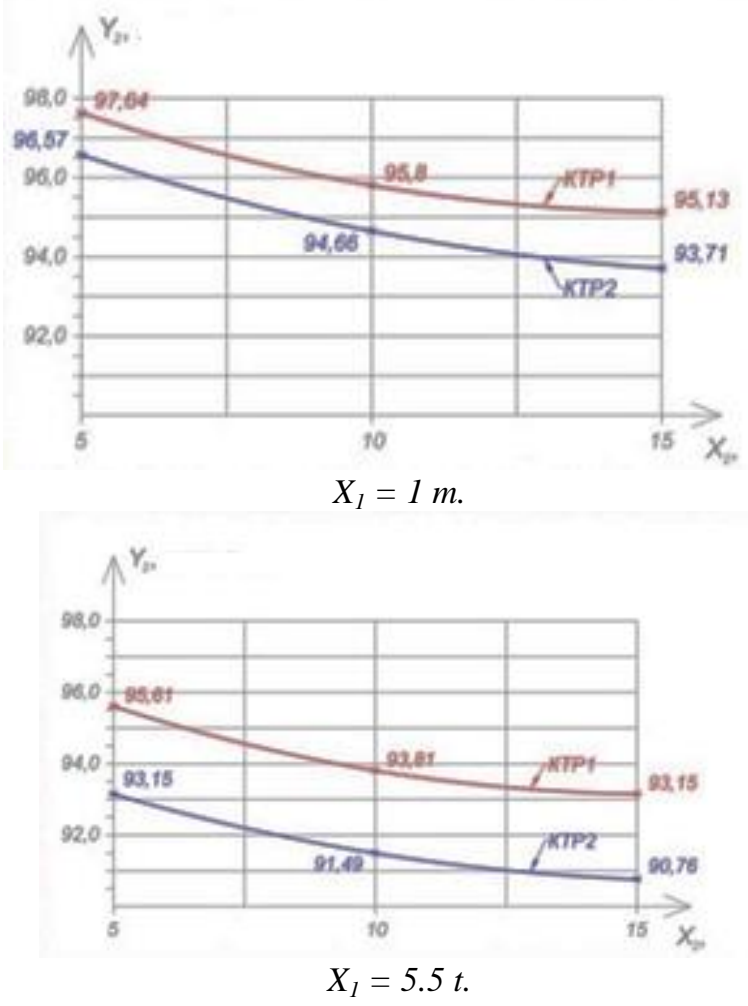


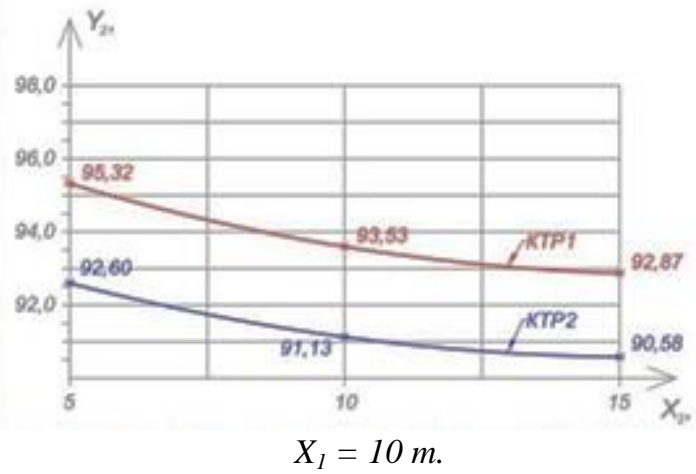

Fig. 10. Total costs for the project with charges $\left(Y_{2}\right)$ when changing the fixing factor $X_{2}$ and $X_{1}$ at levels 1, 5.5, 10 t. For different constructive and technological solutions temporaries
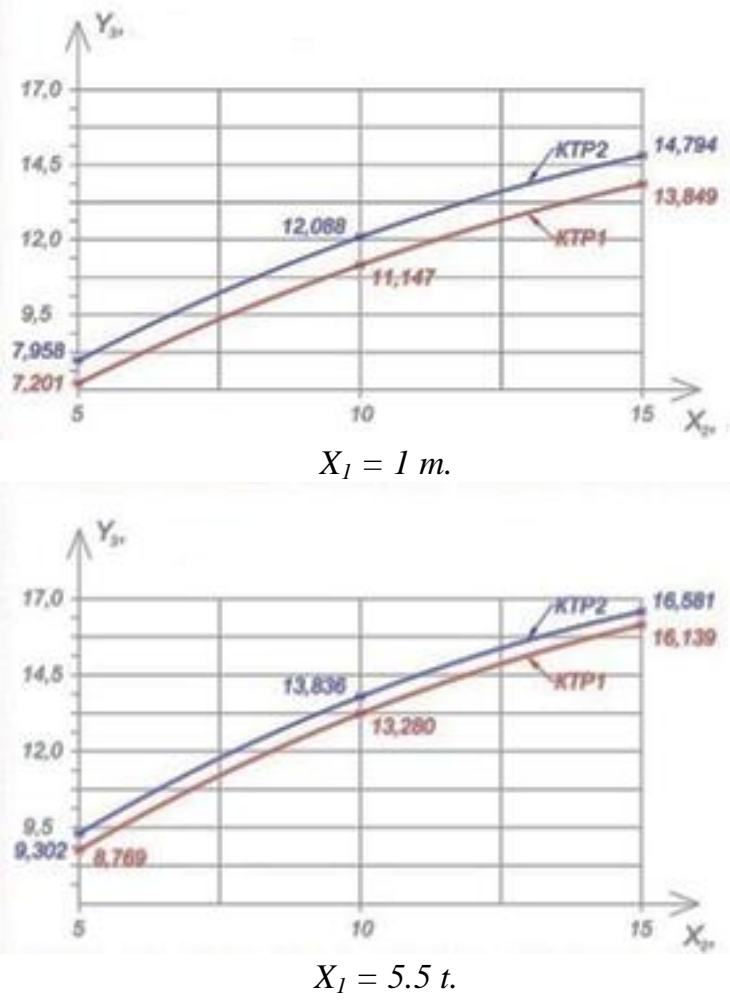


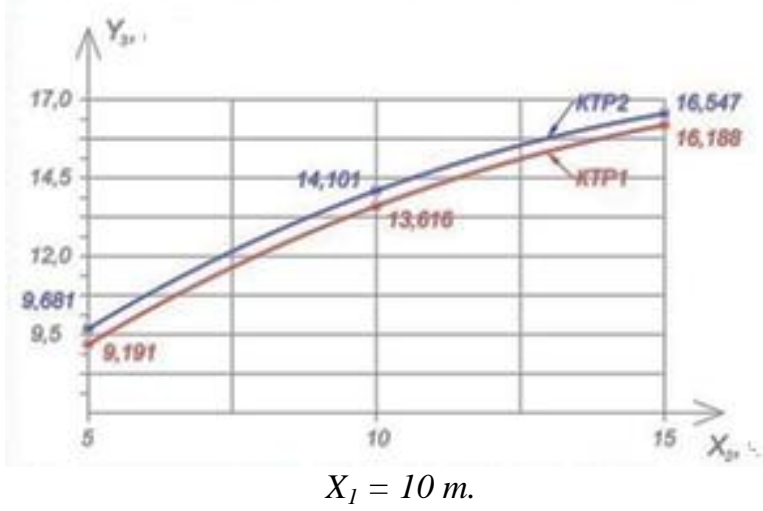

Fig. 11. Intensity project financing $\left(Y_{3}\right)$ when changing the fixing factor $X_{2}$ and $X_{1}$ at levels 1, 5.5, 10 t. for different constructive and technological solutions temporaries

\section{CONCLUSIONS}

1. In this paper we solved the problem of optimizing the design and technological solutions of emergency measures by the example of Shukhov radio tower. There were found regularities of change of the duration of the installation of temporary supporting structures, the total costs of the action with charges and monthly financing intensity of the project through the planning of numerical experiments and experimental-statistical modeling of manufacturing processes with the use of modern software products.

Used experimental design allows to get adequate results and to compare two versions of design and technological solutions of emergency measures at the levels of technological change (the degree of integration of elements mounted columns) and organizational (the number of workers employed in the installation of metal) factors.

Simulation of emergency measures showed a wide margin of changes in the studied parameters:

Duration of installation temporary supporting structures - from 316 to 73 days (4,33 times) with embodiment variant № 1; from 269 to 63 (at 4.27 times) with embodiment variant № 2 .

The total costs of the action with charges - 98474.2192906 .9 thousand rubles (6\%) under option variant № 1; from 96673 to 90539.65 (6.77\%) with embodiment variant № 2.

The monthly financing intensity of the project - from 7160.3816285 .84 thousand rubles/month (2.27 times) in the embodiment variant № 1; 7903.7216 642.98 thousand rubles/month (2.1 times) under option variant № 2. 
Analysis of factors influence the degree to figures revealed the following values of their ranking:

At time duration mounting bearing structures - the number of workers engaged in installation hardware $\left(\mathrm{X}_{2}\right) 100 \%$ with embodiment variant № 1 embodiment with $100 \%$ variant № 2; the degree of integration of elements mounted columns $\left(\mathrm{X}_{1}\right)$ at $32.7 \%$ variant № $1,34.8 \%$ with embodiment variant № 2 .

On the full cost of the project with charges $-X_{1}$ is $92.5 \%$ under option variant № $1100 \%$ under option variant № $2 ; 100 \% \mathrm{X}_{2}$ embodiment when variant № $168 \%$ with embodiment variant № 2.

The intensity of the funding for the project $-\mathrm{X}_{2}$ is $100 \%$ under option variant № 1 , is $100 \%$ under option variant № 2 ; is $32.9 \%$ when $\mathrm{X}_{1}$ variant № 1 variant, is $26.8 \%$ with embodiment variant № 2 .

\section{SUMMARY}

The paper analyzes the structural and technological design solutions for emergency repair works on engineering structures on the example of Shukhov Tower in Moscow. There were selected indicators that fully reflect the project of reconstruction and the most influencing factors. An algorithm was developed for optimizing organizational solutions by experimental statistical modeling and the use of modern software in the field of project management. There was considered the operation of the installation of steel structures for various design and technological solutions and proposed raising factors for cost and time-consuming work. There were developed organizational, technological, financial and economic model of the solutions under consideration according to the experimental plan. According to the values of the indicators there was fixed experimental design and was chosen the second degree polynomial model, which corresponds to the planned experiments. There was conducted simulation in specialized software and obtained experimental statistical laws change indicators (installation time, the full cost of the project, the funding intensity of the project) from factors (degree of pre-assembly mounted element metal constructions columns, the number of workers involved in the installation of the metal constructions) for two constructive and technological solutions (temporary welded hollow carrier columns with subsequent filling with concrete to the level of 24.65 $\mathrm{m}$.; flange provisional hollow bearing columns filled with concrete to the level of $1.50 \mathrm{~m}$.). There were presented results of experimental statistical modeling and optimization of the project under the given technological constraints on the possible conditions of work and project performance indicators. A graphical way was used to identify the most efficient models of construction in cramped conditions for their implementation. There were recommended optimal conditions for carrying out the construction work. 


\section{REFERENCES}

1. Вознесенский В.А. Статистические методы планирования эксперимента в технико-экономических исследованиях / В.А. Вознесенский // М.: Финансы и статистика, 1981. - 263с. 7.

2. Адлер Ю.П. Планирование эксперимента при поиске оптимальных условий / Ю.П. Адлер, Е.В. Маркова, Ю.В. Грановский // М. : Наука. - 1-е изд., 1971. - 283 с. - 2-е изд., 1976. - 279 с.

3. Налимов В.В. Теория эксперимента. / В.В. Налимов // М. : Наука, 1971. $-208 \mathrm{c}$.

4. Краковский Г.И. Планирование экспериментов / Г.И. Краковский, Г. Ф. Филаретов. // Минск: БТУ, 1982. - 757 с.

5. Вознесенский В.А. Численные методы решения строительнотехнологических задач на ЭВМ / В.А. Вознесенский, Т.В. Ляшенко, Б.Л. Огарков // К. : Вища школа, 1989.-328. с.

\section{Information about the author:}

Menejljuk O. I.,

Doctor of Technical Sciences, Full Professor, Odessa State Academy of Civil Engineering and Architecture 4, Didrihsona str., Odesa, 65029, Ukraine 


\section{STRENGTHENING OF REINFORCED CONCRETE BEAM STRUCTURES USING EXTERNAL REINFORCEMENT. EFFICIENCY RESEARCH}

\section{Molodid A. S.}

\section{INTRODUCTION}

Along with the development of the latest technologies in the construction of new structures, the reconstruction and major overhaul of existing buildings is also an important part of the construction complex, which needs improvement. One of the most common types of construction works performed during the renovation of buildings is the strengthening of reinforced concrete beam structures, namely: crossbars, floor slabs, coverings, beams, etc. Usually, in practice, to strengthen these structures, the following methods are used: increase in cross-section due to build-up; change of static scheme of work due to installation of tighteners, struts, racks, etc. ${ }^{1}$. However, sometimes the installation of additional, bulky, reinforcement designs is unacceptable because it causes changes in construction design and layout decisions of the interior space of the building at the same time significantly increasing the load on the bearings and the foundations.

In this case, the method of reinforcing structures through external reinforcement is quite effective and advisable ${ }^{2}$. The principle of such

${ }^{1}$ DSTU B V.3.1-2: 2016. Repair and strengthening of bearing and enclosing building constructions and foundations of buildings and structures [Effective from 2017-04-01]. - Kyiv: SE "UkrNDNTS", 2017. - 72 p.; Ignatova I.V. Strengthening of concrete structures with the help of a polymer-silicate composition / I.V. Ignatova // Building Constructions: a collection of scientific works. - Kyiv, SE "NDIBK", 2011. - Issue number 75, Book 2. - pp. 614 - 621.; Rekomendatsyy po vosstanovlenyyu y usylenyyu polnosbornykh zdanyy polymerrastvoramy. [Recommendations for the restoration and strengthening of full-fledged buildings by polymer materials] TbilZNIIEP. - Moscow: Stroyizdat, 1990. - 160 p.; Minnaugh P. L. The experimental behavior of steel fiber reinforced polymer retrofit measures: thesis master of Science / Patrick Lucien Minnaugh; University of Pittsburgh school of engineering. Pittsburgh, $2006-113$ p.

${ }^{2}$ Rekomendatsyy po vosstanovlenyyu y usylenyyu polnosbornykh zdanyy polymerrastvoramy. [Recommendations for the restoration and strengthening of full-fledged buildings by polymer materials] TbilZNIIEP. - Moscow: Stroyizdat, 1990. - 160 p.; Savyovsky V. V. reconstruction of buildings and constructions / V. V. Savyovsky - Kiev, «Lira-K», 2018. - 320 p.; Savyovsky V. V. Strengthening of reinforced concrete beam structures by external reinforcement / V.V. Savyovsky, O. S. Molodid, N.O. Malets // Development Management of complex systems. - 2017 - № 29. pp. 198 - 204.; Grigorovsky P. E. Strengthening of beam structures by external reinforcement by the 
reinforcement consists in glueing additional reinforcement in the form of high-strength cloths, plates or strips (lamels) using special glues on the surface of reinforced structures ${ }^{3}$, Fig. 1. Both metal and composite materials based on carbon fibers and fiberglass are used as external reinforcement ${ }^{4}$.

Exterior reinforcement technology has several advantages over classic techniques, because of the simplicity of the work; the reinforcement elements do not overload the structure as they have a relatively small mass and do not change the design and layout solutions of the interior spaces. The high cost of carbon materials can be attributed to the disadvantages of this technology.

During the inspection of the 5-storey frame-monolithic building in Kiev, a number of damages and defects of structures of inter-storey monolithic reinforced concrete floors were revealed. Numerous damages in the form of cracks located in the stretched zones of beam structures were found on the surface of building structures of beams and slabs of floor-to-ceiling slabs. It was found that the damage was formed as a result of the influence of structural, technological and operational factors, in particular: insufficient reinforcement of stretched zones; overload of structures; discrepancy of thickness of a protective layer to design decisions and normative requirements; durability of concrete is lower than specified in the project; thickness of a slab, in separate places, is less than design; probable early the formwork can be removed.

After cleaning by sandblasting the lower surface of one floor slab, the directions of formation of cracks of their length and width of disclosure are established (Fig. 1,2). Cracks are mainly located along the lower working armature in the protective layer of the stretched zone of the structure. The total length of cracks on the specified slab floor area of $250 \mathrm{~m} 2$ was approximately $368 \mathrm{~m}$. p., including:

Three monolithic reinforced concrete beams, which take the load from the walls, enclosing the landing of all floors located above, were found on the section of the basement floor overlap. Vertical and inclined cracks with

method of adhesion of high-strength fabrics / P. E. Grigorovsky, O. S. Molodid, R. O. Plokhuta // Building Production. - 2016 - No. 61/1. - pp. 13 - 18 .

${ }^{3}$ Technological map for the restoration of brick and reinforced concrete structures and their protection / LLC «Composite». - Kyiv, 2009. - 7 p.; Shagin A.L. Reconstruction of buildings and structures / A.L. Shagin, Yu. V. Bondarenko, D.F. Goncharenko. - Moscow, Higher Education, 1991. - 352 p.; Obaidat Y. T. Structural retrofitting of reinforced concrete beams using carbon fibre reinforced polymer: Licentiate Dissertation / Yasmeen Taleb Obaidat; Division of Structural Mechanics, LTH, Lund University. - Sweden, May, 2010 - 88 p. ISSN 0281-6679

${ }^{4}$ Shilin A.A. Strengthening of reinforced concrete structures using composite materials / A.A. Shilin, V.A. Pshenichny, D.V. Kartuzov. - Moscow: Publishing House «Stroiizdat», $2004-144$ p. 
opening width up to $0.3 \mathrm{~mm}$ were revealed on the surface of these beams (Fig. 3).

According to the results of visual and instrumental examination and verification calculations of beam structures and floor slabs, it was found that the technical condition of the structures does not provide sufficient bearing capacity for their normal and safe further operation for its intended purpose. Therefore, specialists of SE «Research institute of building production» (Kyiv) were recommended to perform their strengthening.

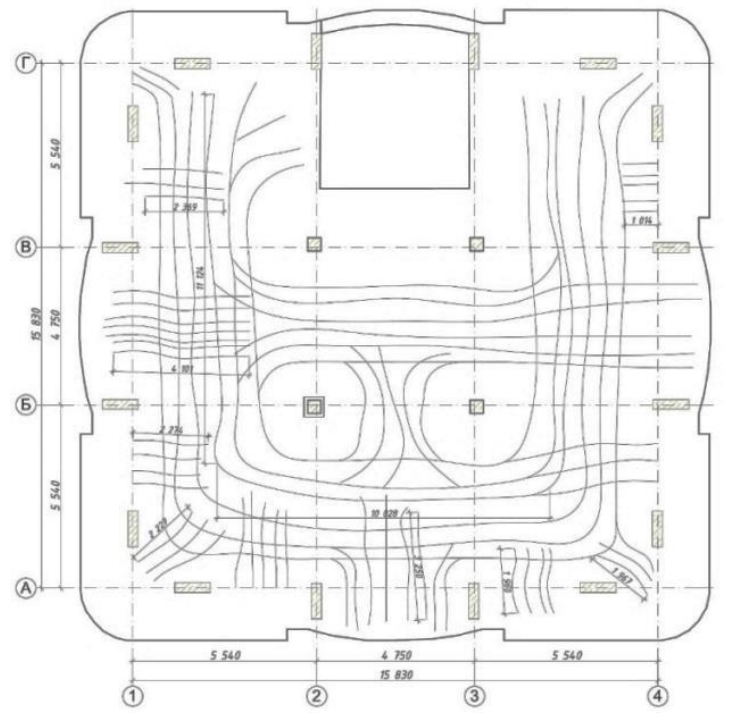

Fig. 1. Diagram of the location of cracks found on the lower surface (ceiling) of the ceiling

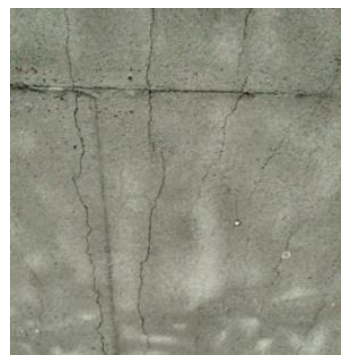

a)

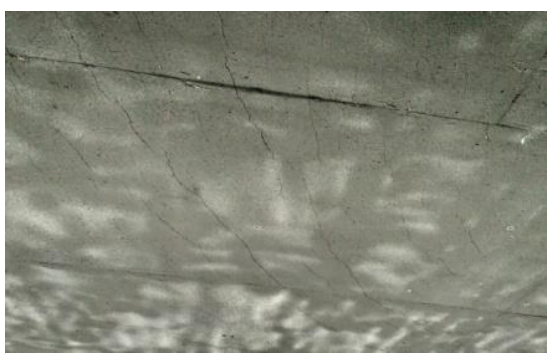

б)

Fig. 2. Cracks on the surface of the slab: a-longitudinal; b-envelope 


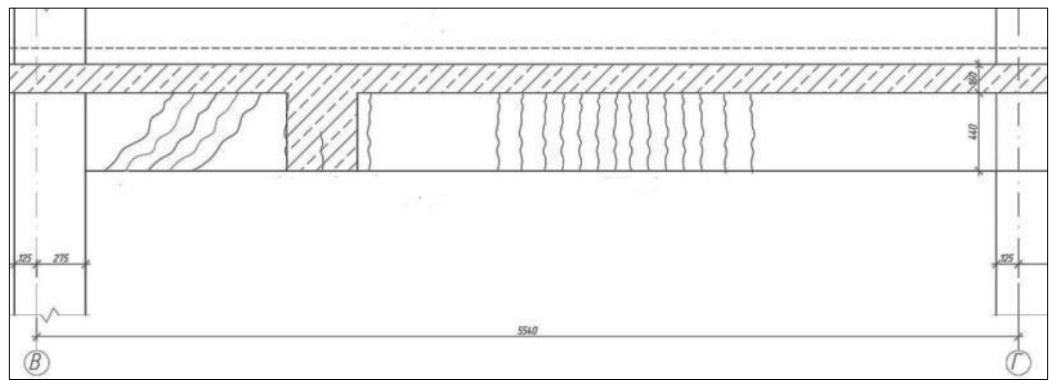

Fig. 3. The scheme of the location of cracks on the surface of the longitudinal beam of the ceiling above the basement

At the first stage of research of efficiency and choice of an optimum variant of strengthening of designs by external reinforcement a number of experimental researches in laboratory of GP «NIISP»was carried out. The purpose of such studies, as noted above, was to test the effectiveness of strengthening reinforced concrete beam structures system using carbon fibers and the search for alternative systems to it from cheaper materials. The load-bearing capacity of reinforced concrete beam structures for bending was adopted as a criterion of efficiency.

During the research the reinforcement of the stretched zone of reinforced concrete beams was performed in the following ways:

- carbon fiber bonding;

- gluing fiberglass threads;

- bonding of steel strips;

- bonding of steel parts.

The study used beams in the form of reinforced concrete partitions type $1 \mathrm{~PB}$ 10-1 with the following characteristics: dimensions (length $\mathrm{x}$ width $\mathrm{x}$ height) 1030x120x65 mm; weight of the structure-20 kg; concrete class C12 / 15.

Reinforcement of beams with carbon fiber was performed using materials and technology of MapeWrap C UNI-AX system developed by the manufacturer «MAPEI» (test series No. 4) ${ }^{5}$. The use of the system MapeWrap C UNI-AX provides the following technological sequence: preparation of the surface cross members; the preparation and application MapeWrap Primer 1; the preparation and application MapeWrap 11; preparation and application MapeWrap 31; preparation and impregnate the fabric with MapeWrap 31; stacking and smoothing carbon fiber MapeWrap C UNIAX; applying a second layer of MapeWrap 31.

\footnotetext{
${ }^{5}$ Mapewrap C UNI-AX. Coating high-strength carbon fiber unidirectional. [e-resource]. Available at: http://rosmax.com.ua
} 
Other three alternative ways of strengthening of beam designs are executed according to recommendations of the producer of composite materials LLC «Composite» ${ }^{6}$ and on the basis of the previous similar researches (series of tests № $1,2,3)^{7}$. Strengthening of beams is executed on the following technology: cleaning of a surface; Drawing a layer of a polymeric composition «Konsolid$1 »$; drawing of glue «Edmok»; gluing of elements of strengthening.

The test was performed for four series of ways to strengthen structures with external reinforcement (Fig. 4, 5).

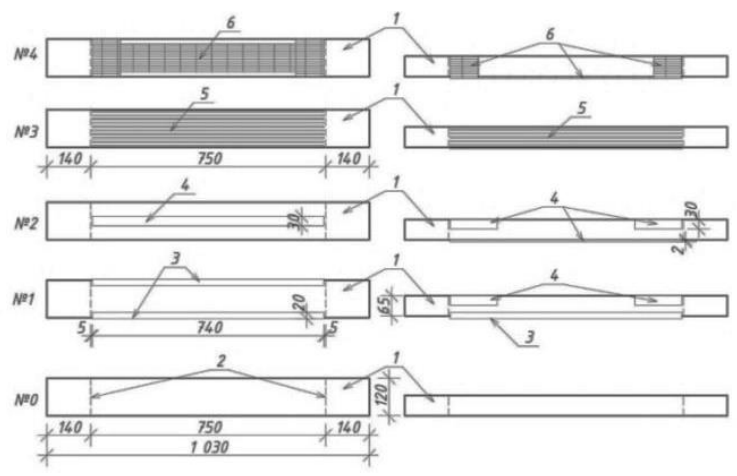

Fig. 4. Schemes of strengthening of beams by external reinforcement:

1-a beam; 2 - places of a support; 3 -a steel corner; 4-a steel strip;

5-glass fiber; 6-carbon fiber; No. 0... No. 4-test series numbers

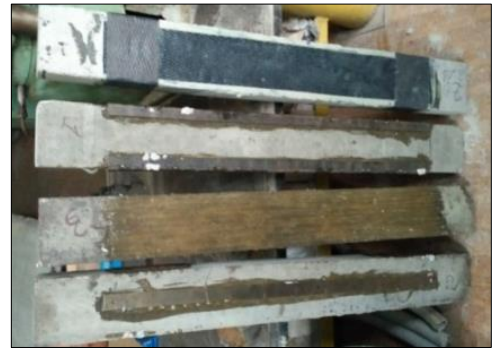

Fig. 5. Strengthening of beams by the given options of external reinforcement

\footnotetext{
${ }^{6}$ Technological map for the restoration of brick and reinforced concrete structures and their protection / LLC «Composite». - Kyiv, 2009. - 7 p.

${ }^{7}$ Savyovsky V. V. Strengthening of reinforced concrete beam structures by external reinforcement / V.V. Savyovsky, O.S. Molodid, N.O. Malets // Development Management of complex systems. - 2017 - № 29. - pp. $198-204$.
} 
Test series № 0 is made for control beams. With beams did not perform any action-reinforcement is not added. In the test series № $1,20 \times 3 \mathrm{~mm}$ steel corners were glued to the lower corners of the beams, and steel plates were glued to the upper support zones. For series of tests № 2 to the lower the surface beams and in the upper priopornikh zones glued steel swathe of wide $30 \mathrm{~mm}$ and, measuring $2 \mathrm{~mm}$. Series of tests № 3 envisaged the spraying on the lower and lateral the surface beams adhesive mortar, in which evenly «dipped» 10 threads fiberglass on an effort, and on 5 threads on lateral the surface. In series of tests № 4 strengthening met system MapeWrap C UNI-AX with gluing carbon fiber on the lower the surface beams with an additional gluing all carbon fiber wound on lateral the surface in priopornikh zones.

Elements of external reinforcement were not brought to $5 \mathrm{~mm}$ to the support zone.

Test on installation of bearing capacity of beams on a bend is carried out on the hydraulic press P-50 through $96 \mathrm{~h}$ after gluing of external reinforcement.

Tests are executed, for the static scheme-as for beams on two supports with a span of $750 \mathrm{~mm}$. loading of beams was carried out through two steel tubes equidistant from supports and among themselves, that is two concentrated efforts (Fig. 6).

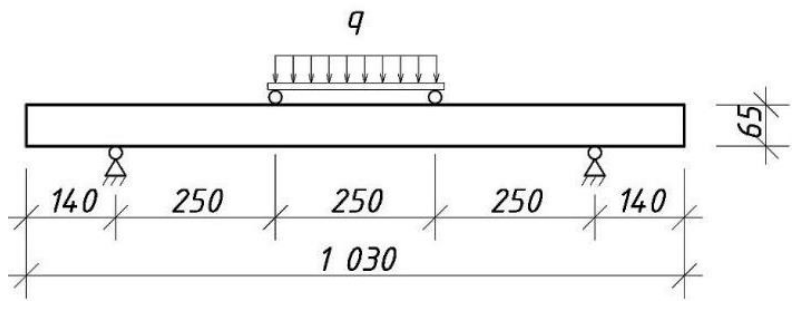

\section{Fig. 6. Scheme of loading of the tested reinforced concrete beams}

Step-by-step loading of beams with an increase in load by $50 \mathrm{~kg}$ at each step with an endurance for $3 \mathrm{~min}$. the Tests were carried out until the complete destruction of the beams. The results of experimental studies are given in table. 1. The nature of the destruction of beams reinforced in various ways is shown in Fig. 7. 
The results of experimental studies

to establish the destructive force of beams

\begin{tabular}{|c|c|c|c|}
\hline $\begin{array}{c}№ \\
\text { series } \\
\text { of tests }\end{array}$ & $\begin{array}{l}\text { Average } \\
\text { breaking } \\
\text { force, } \mathrm{kg}\end{array}$ & $\begin{array}{c}\text { The average } \\
\text { breaking } \\
\text { force, \% }\end{array}$ & Character of destruction for beams \\
\hline 0 & 407 & 100 & \\
\hline 1 & 1400 & 343,9 & $\begin{array}{l}\text { Tearing off the edges of the corners } \\
\text { with the formation of an inclined crack in the } \\
\text { support zone. }\end{array}$ \\
\hline 2 & 1200 & 294,8 & $\begin{array}{l}\text { Destruction of concrete in the middle of } \\
\text { beams. The plate is intact. }\end{array}$ \\
\hline 3 & 1300 & 319,4 & $\begin{array}{l}\text { Destruction on the middle of beams with } \\
\text { breaking of glass fiber on the lower plane }\end{array}$ \\
\hline 4 & 1700 & 417,6 & $\begin{array}{l}\text { Destruction of the beam in the supporting zone } \\
\text { with the formation of an inclined crack }\end{array}$ \\
\hline
\end{tabular}

The analysis of the results of experimental studies showed that the highest load-bearing capacity of beam structures was achieved in variants with external reinforcement by MapeWrap C UNI-AX system with carbon fiber $(1700 \mathrm{~kg}$ ) (study series № 4). Also, the average breaking force increased more than three times with the reinforcement of structures with metal corners and fiberglass and amounted to $1400 \mathrm{~kg}$ and $1300 \mathrm{~kg}$ for research series № 1 and № 3. A slightly worse result was obtained when reinforcing the beams with steel plates where the average breaking force was $1200 \mathrm{~kg}$.

In the second stage of efficiency studies scientific studies were carried out to assess the economic feasibility of using a specific method of strengthening the floor slabs. For this purpose the following methods of amplification were compared: supply of metal beams with the installation of additional supports, external amplification under the «MAPEI» technology and external reinforcement under the previously researched and proposed technologies. Provided research and comparison of technical and economic indicators for overlappings with area of $250 \mathrm{~m}^{2}$, where outer loop is based on the piers and columns support it in the middle (Fig. 8, 9).

The main technical and economic performance indicators (TEP) selected for comparison: cost of materials for amplification, complexity, wages and performance duration.

By the first method, the reinforcement of the floor slab is provided by the supply of metal beams with the installation of additional supports (columns) (Fig. 8). Since, when performing amplification by the indicated method, the height of the room is significantly reduced, but in this case it is not acceptable, therefore this method is considered only for the purpose of comparison of the TEP. 

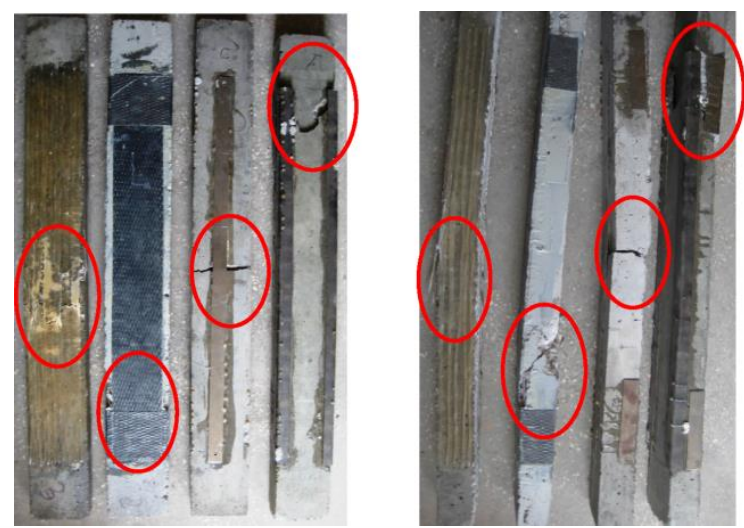

Fig. 7. Character of destruction of the beams strengthened by various methods with reflection of places of destruction

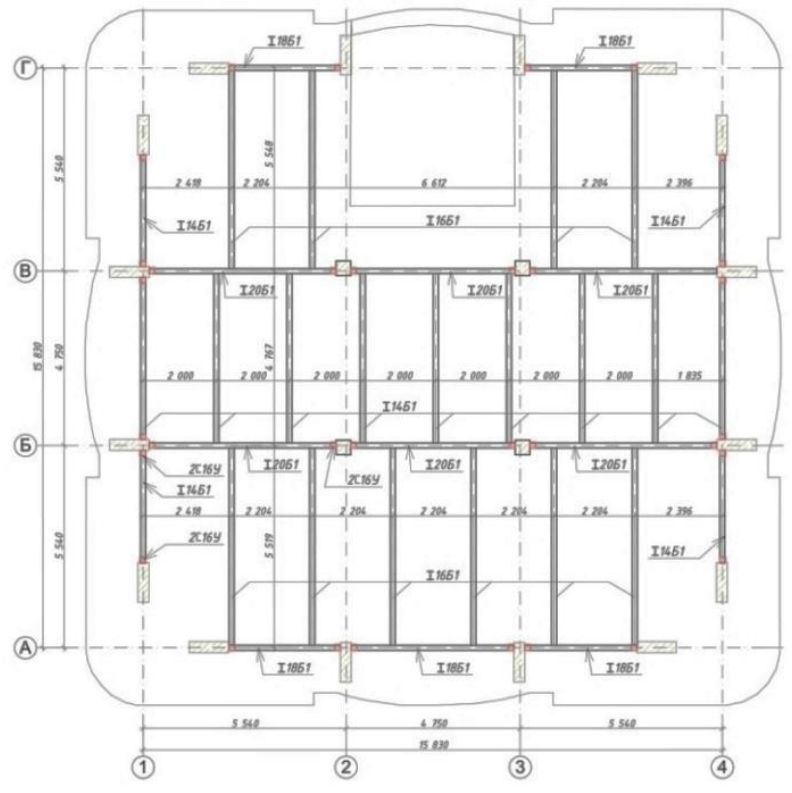

Fig. 8. Scheme of reinforcing elements of the floor slab according to the method of supplying steel beams with the installation of additional columns 
The project provides for the installation of rigidly fixed metal columns (two 16U wires welded in a box) to existing reinforced concrete vertical structures in the areas shown in Fig. 8. On the columns are laid and welded longitudinal double T-beams 18B1 and 20B1 on the lower shelves of which through inserts (if necessary) are laid and welded transverse double T-beams 14B1 and 16B1.

The following methods provide external reinforcement of slabs made of reinforced concrete, such as bonding metal plates or carbon fiber on the stretched zones. This will allow increasing bearing capacity of the plate and reducing deflection. The areas for adhesion of strips for external reinforcement are shown in the schematic of the reinforcement elements (Fig. 9).

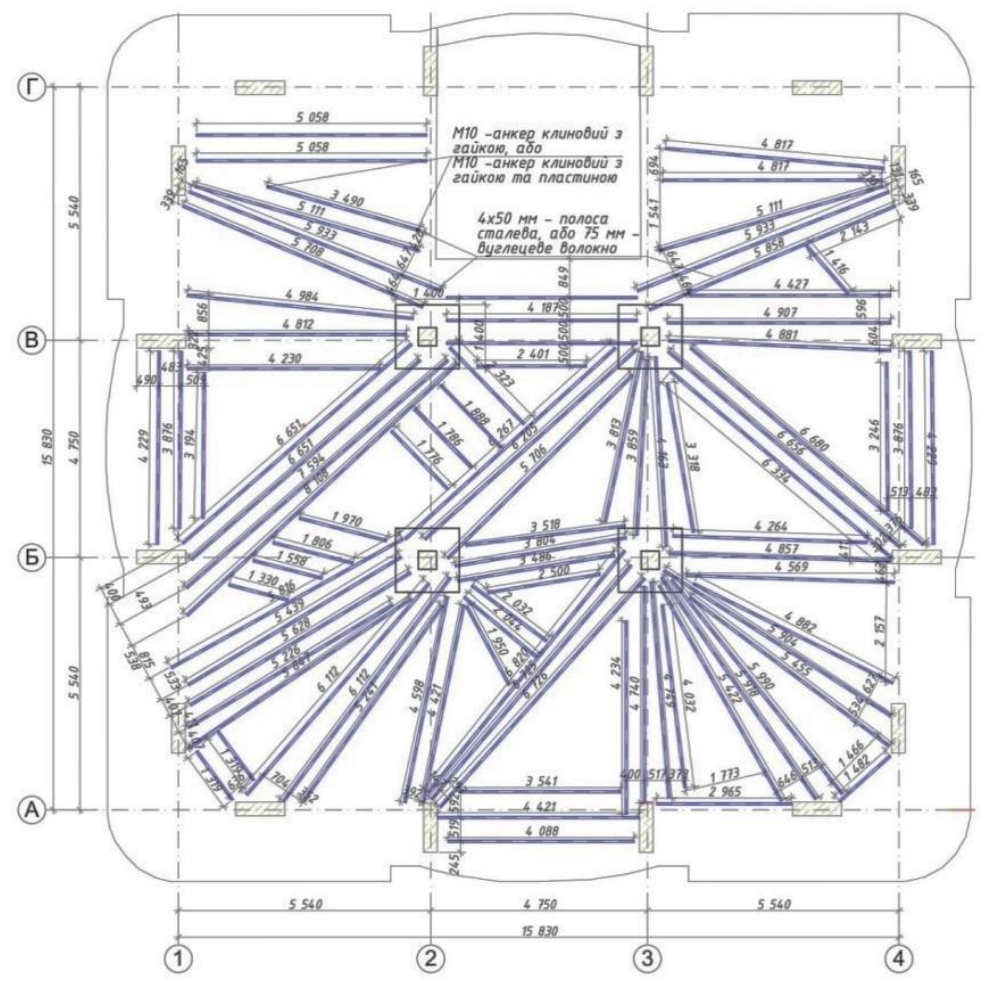

Fig. 9. The layout of the elements of reinforcement of the floor slab with the method of external amplification (MAPEI technology, metal plates, or carbon fiber under developed technology) 
By the second method, the reinforcement of the floor slab is performed according to the technology of the «MAPEI» company. Prior to the beginning of the reinforcement work, future carbon fiber bonding sites should be cleaned from the "glossy» surface using a sandblasting device, or a grinding machine with a special disk to clear concrete surfaces. This technology provides for priming the concrete surface to strengthen the foundations with composition MapeWrap Primer 1, bonding unidirectional carbon fiber MapeWrap C UNI-AX with adhesive MapeWrap 21. The ends of the strips of carbon fiber mechanically fixed with metal plates and bolts M10.

In the third method is scheduled to perform enhancement of the plate by sticking metal plates to its stretched areas. Firstly, the cleaning of the places for gluing plates is carried out according to the technology described above. Subsequently, the place of gluing the plates and $10 \mathrm{~mm}$ on each side outside each plate is impregnated with the composite grounding foundation «Consolid 1» manufactured by LLC «COMPOSIT». At least 24 hours later bonding of metal plates $(4 \times 50 \mathrm{~mm})$ is executed on an epoxy based adhesive «EDMOK» produced by LLC «COMPOSIT». At the ends the plates are fixed with wedge anchors M10. Plates are pre-wiped to shine and degreased.

By the fourth method, the reinforcement is performed by gluing of strips of unidirectional carbon fiber on the stretched zones. Before the beginning of the gluing work, place intended for bonding the fiber is prepared, namely, the surface is cleaned and «Consolid 1» foundation is applied as described in the previous method. After 24 hours «EDMOK» adhesive is applied on the prepared surface and strips of carbon fiber are «drown» in it with a spatula. In 5-10 minutes, another layer of «EDMOC» adhesive is applied to the surface of the fiber so that it completely percolates the fiber and remains on the surface. The ends of carbon fiber strips are mechanically fixed with metal plates and bolts M10.

First of all, we are going to establish the cost of the materials necessary for the work on reinforcing the floor slab for each of the technologies described. The total cost of materials and equipment is determined by the formula (1):

$$
\mathrm{P}_{\mathrm{M}}=\sum_{\mathrm{i}=1}^{\mathrm{n}}\left(\rho_{\text {мп }} \cdot \mathrm{Q}_{\text {мп }}\right),
$$

where $\rho_{\mathrm{Mn}}-$ total value of the products of each individual material;

$\mathrm{Q}_{\mathrm{Mn}}$ - the volume of each individual material.

For the first method is defined the overall length of each type of steel elements and multiplied by its density, double T-beams $14 \mathrm{~B} 1=571.41 \mathrm{~kg}$, 
$16 \mathrm{~B} 1=698.5 \mathrm{~kg}, 18 \mathrm{~B} 1=256.41 \mathrm{~kg}, 20 \mathrm{~B} 1=659.2 \mathrm{~kg}$; Channel for columns $16 \mathrm{U}=2905,32 \mathrm{~kg}$.

Consequently, the total cost of metal elements is:

$$
\begin{aligned}
P_{\mathrm{M}}=23,2 \mathrm{UAH} / \mathrm{kg}(571,4 \mathrm{~kg}+698,5 \mathrm{~kg}+256,4 \mathrm{~kg}+659,2 \mathrm{~kg}+2905,3 \mathrm{~kg}) \\
=118106,5 \mathrm{UAH},
\end{aligned}
$$

where 23,2 is the cost of one kilogram of steel constructions.

For the second method it is established that in order to strengthen the stretched zones of the slab floor, $376 \mathrm{rm}$ of carbon fiber MapeWrap C UNIAX 300/10 is required, which, with a strip width of $10 \mathrm{~cm}$ has a density of $300 \mathrm{~g} / \mathrm{m}$. The cost of such carbon fiber is $154.7 \mathrm{UAH} / \mathrm{rm}$.

Thus, the cost of fiber needed to strengthen the entire plate is:

$$
\mathrm{P}_{\mathrm{M}}=154,7 \mathrm{UAH} / \mathrm{rm} \times 376,0 \mathrm{rm}=58167,2 \mathrm{UAH} .
$$

The MapeWrap Primer 1 priming fluid consumption is $11.28 \mathrm{~kg}$. With the price of $1 \mathrm{~kg}$ of grounding 740,76 UAH, its total cost will be:

$$
\mathrm{P}_{\mathrm{M}}=740,7 \mathrm{UAH} / \mathrm{kg} \times 11,28 \mathrm{~kg}=8355,7 \mathrm{UAH} .
$$

For adhesion of carbon fiber, adhesive MapeWrap 21 is used with a total consumption for an overlapping amounting $37.6 \mathrm{~kg}$. The price of glue is $553,97 \mathrm{UAH} / \mathrm{kg}$, so its total cost will be:

$$
\mathrm{P}_{\mathrm{M}}=553,9 \mathrm{UAH} / \mathrm{kg} \times 37,6 \mathrm{~kg}=20829,2 \mathrm{UAH} .
$$

For the third method of amplification, analyzed in this article, is needed $581.0 \mathrm{~kg}$ of steel strip $4 \times 50 \mathrm{~mm}$ at its price of $23.2 \mathrm{UAH} / \mathrm{kg}$. Consequently, the total cost of the steel strip for reinforcing the plate is:

$$
\mathrm{P}_{\mathrm{M}}=23,2 \mathrm{UAH} / \mathrm{kg} \times 581,0 \mathrm{~kg}=13479,2 \mathrm{UAH} .
$$

The total cost of the grounding «Consolid 1» will be:

$$
\mathrm{P}_{\mathrm{M}}=227 \mathrm{UAH} / 1 \times 9,51=2156,5 \mathrm{UAH}
$$

with its need amounting 9.5 liters and a price of $227 \mathrm{UAH} / \mathrm{liter}$.

The total cost of adhesive "EDMOC», which will be used when amplifying the plate according to this technology, is: 


$$
\mathrm{P}_{\mathrm{M}}=288,0 \mathrm{UAH} / \mathrm{kg} \times 28,2 \mathrm{~kg}=8121,6 \mathrm{UAH}
$$

at its price $288 \mathrm{UAH} / \mathrm{kg}$ and need $28.2 \mathrm{~kg}$.

For the fourth method of amplification requires $376.0 \mathrm{rm}$ of unidirectional carbon fiber with density of $300 \mathrm{~g} / \mathrm{rm}$ and a width of a strip of $10 \mathrm{~cm}$, as indicated above, at a price of $125.0 \mathrm{UAH} / \mathrm{m}$. Under these conditions, the total cost of fiber for the plate reinforcement will make:

$$
\mathrm{P}_{\mathrm{M}}=125,0 \mathrm{UAH} / \mathrm{rm} \times 376,0 \mathrm{rm}=47000,0 \mathrm{UAH} .
$$

The total cost of the grounding «Consolid $1 »$ is:

$$
\mathrm{P}_{\mathrm{M}}=227,0 \mathrm{UAH} / \mathrm{l} \times 15,71=3564,0 \mathrm{UAH}
$$

with its need for 15.7 liters and a price of 227.0 UAH/liter.

The total cost of adhesive «EDMOC», used when amplifying the plate according to this technology, is:

$$
\mathrm{P}_{\mathrm{M}} \mathrm{P}_{\mathrm{M}}=288,0 \mathrm{UAH} / \mathrm{kg} \times 75,2 \mathrm{~kg}=21657,6 \mathrm{UAH}
$$

As the need for glue «EDMOC» is $75.2 \mathrm{~kg}$, and its price $-288 \mathrm{UAH} / \mathrm{kg}$.

The calculation of the cost of materials needed to reinforce the floor slab is given in Table 2 and in Fig. 10.

The second phase of the study TEP provides establishment of complexity and amount of wages for performed work at strengthening plates with different technologies. The complexity is determined by the normative values in accordance with the DBN, SGS, DSTU and Unified Norms and Prices, as well as by the values obtained by the results of their own timing. All labor complexity values are summarized in Table 2 .

Wages, salaries of workers performing amplification are defined in UAH based on the data book «Pricing in construction». The indicated costs are $20.5 \mathrm{UAH} /$ hour for the worker with a grade of 3.8. The calculation of labor and wages is shown in Table 2. The histogram of labor intensity (Fig. 11) and wages (Fig. 12) on the reinforcement of the plate by different technologies is constructed according to the data of Table 3. 
Table 2

Cost of materials for reinforcement of floor slab by different methods

\begin{tabular}{|c|c|c|c|c|}
\hline \multirow{2}{*}{ Name of material } & \multicolumn{4}{|c|}{ Cost of materials, UAH } \\
\cline { 2 - 5 } & $\begin{array}{c}\text { supply of } \\
\text { metal } \\
\text { beams }\end{array}$ & $\begin{array}{c}\text { «MAPEI» } \\
\text { technology }\end{array}$ & $\begin{array}{c}\text { gluing } \\
\text { metal } \\
\text { plates }\end{array}$ & $\begin{array}{c}\text { gluing } \\
\text { carbon } \\
\text { fiber }\end{array}$ \\
\hline Metal beams and columns & 118106,5 & - & - & - \\
\hline $\begin{array}{c}\text { MapeWrap C UNI-AX } \\
\text { 300/10 }\end{array}$ & - & 58167,2 & - & - \\
\hline MapeWrap Primer 1 & - & 8355,7 & - & - \\
\hline MapeWrap 21 & - & 20829,2 & - & - \\
\hline Steel strip 50×4 & - & - & 13479,2 & - \\
\hline Consolid & - & - & 2156,5 & 3564,0 \\
\hline EDMOK & - & - & 8121,6 & 21657,6 \\
\hline Carbon fiber 300/10 & - & - & - & 47000,0 \\
\hline Anchor M10 & - & 516 & 516 & 516 \\
\hline Steel strip for mechanical \\
fastening & - & 345 & - & 345 \\
\hline Total cost & $\mathbf{1 1 8 1 0 6 , 5}$ & $\mathbf{8 8 2 1 3 , 1}$ & $\mathbf{2 3 7 5 7 , 3}$ & $\mathbf{7 3 0 8 2 , 6}$ \\
\hline
\end{tabular}

Pм, UAH

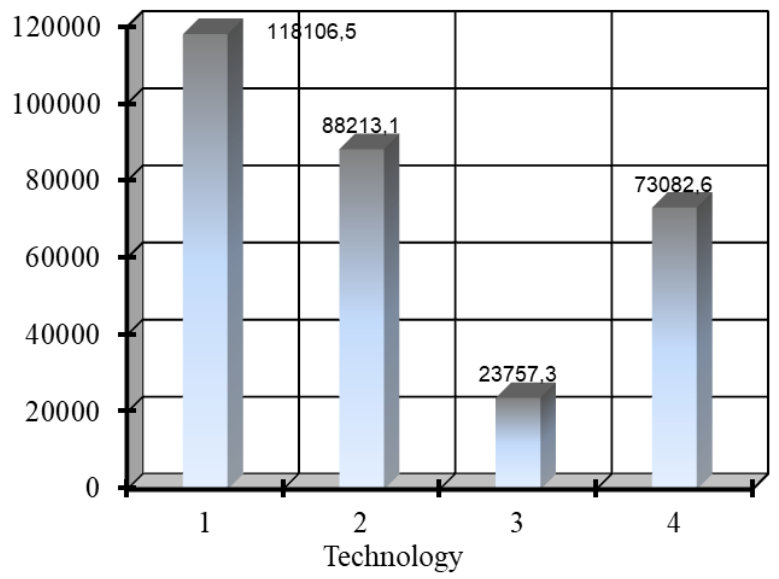

Fig. 10. Cost of materials for reinforcement of floor slab:

1 - supply of metal beams; 2 - «MAPEI» technology;

3 - gluing of metal plates; 4 - gluing carbon fiber

Table 3 


\section{Calculation of labor complexity of reinforcing overlapping slabs}

by different methods and wages for these works

\begin{tabular}{|c|c|c|c|c|c|c|c|c|}
\hline \multirow[b]{3}{*}{ Working operation } & \multicolumn{8}{|c|}{$\begin{array}{l}\text { The complexity and wages to enhance the floor slab according } \\
\text { to the appropriate technology }\end{array}$} \\
\hline & \multicolumn{2}{|c|}{$\begin{array}{c}\text { supply of metal } \\
\text { beams }\end{array}$} & \multicolumn{2}{|c|}{$\begin{array}{l}\text { «MAPEI» } \\
\text { technology }\end{array}$} & \multicolumn{2}{|c|}{$\begin{array}{c}\text { gluing metal } \\
\text { plates }\end{array}$} & \multicolumn{2}{|c|}{$\begin{array}{c}\text { gluing carbon } \\
\text { fiber }\end{array}$} \\
\hline & 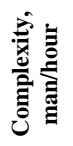 & 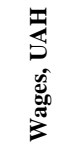 & 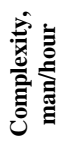 & 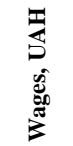 & 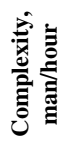 & 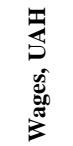 & 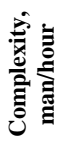 & 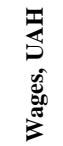 \\
\hline $\begin{array}{l}\text { Painting of metal } \\
\text { elements }\end{array}$ & 28,5 & 584,2 & - & - & - & - & - & - \\
\hline $\begin{array}{l}\text { Cutting, assembly } \\
\text { and welding }\end{array}$ & 478,2 & 9803,1 & - & - & - & - & - & - \\
\hline Cleaning the surface & - & - & 8,8 & 180,4 & 8,6 & 176,3 & 8,8 & 180,4 \\
\hline Priming the surface & - & - & 10,2 & 209,1 & 9,6 & 196,8 & 10,2 & 209,1 \\
\hline Technological break & & & & & & $24 \mathrm{H}$ & & \\
\hline $\begin{array}{l}\text { Gluing Carbon Fiber } \\
\text { / Metal Plates }\end{array}$ & - & - & 55,4 & 1135,7 & 336,3 & 6894,1 & 55,4 & $\begin{array}{c}1135 \\
7\end{array}$ \\
\hline $\begin{array}{l}\text { Fixing ends of } \\
\text { stripes with anchors }\end{array}$ & - & - & 19,2 & 393,6 & 17,6 & 360,8 & 19,2 & 393,6 \\
\hline Total & 506,7 & 10387,3 & 93,6 & 1918,8 & 372,1 & 7628,0 & 93,6 & 1918,8 \\
\hline
\end{tabular}

Q, man/hour

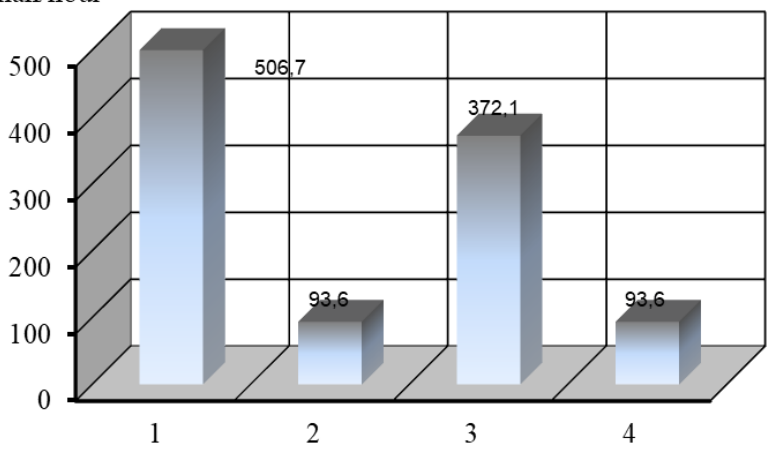

Technology

Fig. 11. The complexity of work on reinforcement of the floor slab:

1 - supply of metal beams; 2 - «MAPEI» technology;

3 - gluing of metal plates; 4 - gluing carbon fiber 


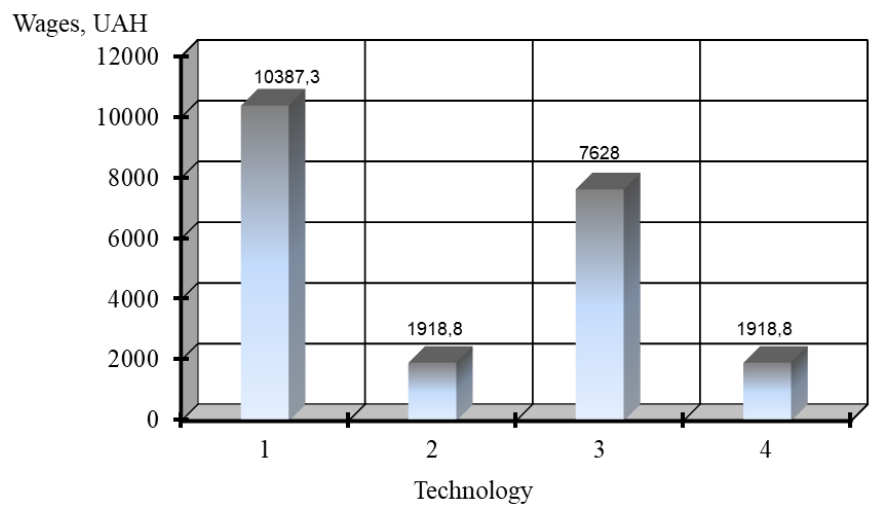

Fig. 12. Wages for strengthening slabs:

1 - supply of metal beams; 2 - «MAPEI» technology;

3 - gluing of metal plates; 4 - gluing carbon fiber

The duration of the process of reinforcing the floor slab (Fig. 13) is determined by adding the duration of the work operations with the length of the technological breaks between them according to the Table 3 . It is taken into account that the painting of metal constructions and surface cleaning is carried out by one worker, the assembly and welding work is carried out by three workers, and all other processes are performed by two workers.

$\mathrm{T}$, changes

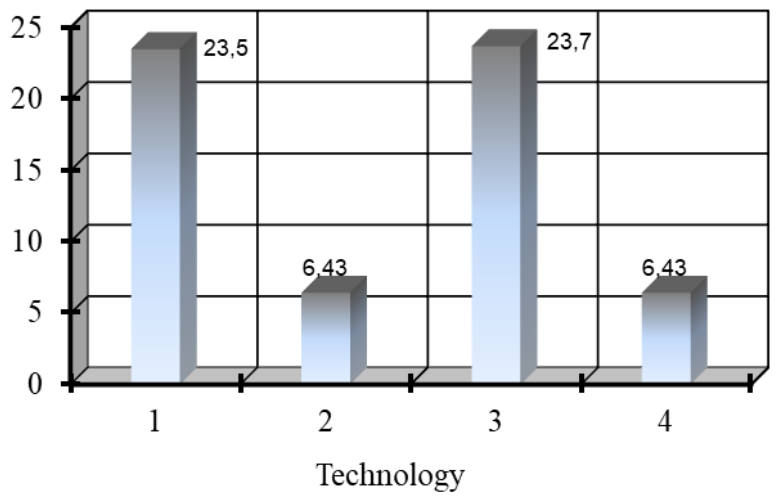

Fig. 13. Duration of work on reinforcement of floor slab:

1 - supply of metal beams; 2 - «MAPEI» technology;

3 - gluing of metal plates; 4 - gluing carbon fiber 
According to the study of technical and economic performance of different amplification technologies applied to the same floor slab it was found that the cost of materials, complexity and wages for performing such works on reinforcing floor slab with the amplification method of supply of metal structures is the highest. At the same time labor intensity, wages and the duration of work execution are the lowest with the reinforcement of the floor slabs by the technology of the company MAPEI and the bonding of carbon fiber by the developed technology. The cost of materials for reinforcing the slab by the developed technology, namely, bonding of steel plates is the lowest, but the complexity, wages and length of work under such technology is much higher than other investigated technologies of reinforcement by external enhancement.

The research results are a strong argument in choosing a particular way of strengthening of structures, namely, one of the components of a variant feasibility study of the decisions taken.

\section{SUMMARY}

Amplification of beam structures is usually performed in several classical ways, in particular: increase in cross-section due to build-up; changing the static scheme of work due to the installation of laggings, beam knees, racks, etc. However, the arrangement of additional reinforcement structures leads to a decrease in inter-floor space, an increase in the load on the supports and foundations and changes in structural and planning decisions of the interior space of the building. An alternative to these methods of reinforcement of beam structures is external reinforcement namely high-tension cloths, plates or strips that are bonded with special adhesives to the surfaces of structures. However, domestic scientific-technical and normative literature actually leaves such methods of amplification out of its attention. That is why a number of experimental studies were carried out to determine efficiency of reinforcing structures under MAPEI technology with the use of carbon fiber and in order to find alternative to domestic technologies. In alternative studies the authors used fiberglass, steel strips and steel angles bonded with special adhesives of domestic production. The efficiency criterion of technologies being tested was adopted bending load capacity of amplified beam structures made of reinforced concrete.

The results of experimental studies found that reinforcement technology MAPEI by applying carbon fiber increases carrying capacity of beams to $417.6 \%$ compared with non-enhanced beams. At the same time, amplification of beams with steel angles increased their bearing capacity by $343.9 \%$, with steel plates - by $294.8 \%$, and with fiberglass - by $319.4 \%$.

The obtained results indicate high efficiency of the investigated methods of strengthening for beam structures and build up the direction of further 
research of organizational and technological solutions for the implementation of external additional reinforcement of beam constructions.

Also the paper presents the results of the study of technical and economic indicators of various methods of reinforcing monolithic reinforced concrete slab, namely: the supply of metal beams with the installation of additional supports, external reinforcement of stretched zones using MAPEI technology, adhesion of metal plates and carbon fiber to the developed technology. It is established that the highest indicators of the cost of materials, labor intensity and wages for the execution of works relate to the option of reinforcing the floor slab by supplying metal structures, and the lowest indicators have options for reinforcing the floor slabs using MAPEI technology and bonding carbon fiber under the developed technology. The cost of materials for reinforcing the plate in the developed technology with the adhesion of steel plates is the lowest, but complexity, wages and the duration of the work on this technology are much higher than other studied technologies of external reinforcement.

\section{REFERENCES}

1. DSTU B V.3.1-2: 2016. Repair and strengthening of bearing and enclosing building constructions and foundations of buildings and structures [Effective from 2017-04-01]. - Kyiv: SE “UkrNDNTS", 2017. - 72 p.

2. Ignatova I.V. Strengthening of concrete structures with the help of a polymer-silicate composition / I.V. Ignatova // Building Constructions: a collection of scientific works. - Kyiv, SE "NDIBK", 2011. - Issue number 75, Book 2. - pp. 614-621.

3. Rekomendatsyy po vosstanovlenyyu y usylenyyu polnosbornykh zdanyy polymerrastvoramy. [Recommendations for the restoration and strengthening of full-fledged buildings by polymer materials] TbilZNIIEP. Moscow: Stroyizdat, 1990. $-160 \mathrm{p}$.

4. Savyovsky V. V. reconstruction of buildings and constructions / V. V. Savyovsky - Kiev, «Lira-K», 2018. -320 p.

5. Savyovsky V. V. Strengthening of reinforced concrete beam structures by external reinforcement / V.V. Savyovsky, O. S. Molodid, N.O. Malets // Development Management of complex systems. - 2017 № 29. - pp. 198-204.

6. Technological map for the restoration of brick and reinforced concrete structures and their protection / LLC «Composite». - Kyiv, 2009. -7 p.

7. Shagin A.L. Reconstruction of buildings and structures / A.L. Shagin, Yu. V. Bondarenko, D.F. Goncharenko. - Moscow, Higher Education, 1991. $-352 \mathrm{p}$. 
8. Shilin AA. Strengthening of reinforced concrete structures using composite materials / A.A. Shilin, V.A. Pshenichny, D.V. Kartuzov. Moscow: Publishing House «Stroiizdat», 2004 - 144 p.

9. Klebearmierung [e-resource]. - Available at: http://www.diamontag.ch.

10. Mapewrap C UNI-AX. Coating high-strength carbon fiber unidirectional. [e-resource]. - Available at: http://rosmax.com.ua

11. Minnaugh P. L. The experimental behavior of steel fiber reinforced polymer retrofit measures: thesis master of Science / Patrick Lucien Minnaugh; University of Pittsburgh school of engineering. Pittsburgh, $2006-113$ p.

12. Obaidat Y. T. Structural retrofitting of reinforced concrete beams using carbon fibre reinforced polymer: Licentiate Dissertation / Yasmeen Taleb Obaidat; Division of Structural Mechanics, LTH, Lund University. Sweden, May, 2010 - 88 p. ISSN 0281-6679

13. Grigorovsky P. E. Strengthening of beam structures by external reinforcement by the method of adhesion of high-strength fabrics / P. E. Grigorovsky, O. S. Molodid, R. O. Plokhuta // Building Production. 2016 - No. 61/1. - pp. 13-18.

\section{Information about the author: Molodid O. S.,}

Ph.D. in Engineering, Associate Professor, Assistant Professor at the Construction Production Technology Department,

Kyiv National University of Construction and Architecture 31, Povitroflotskyi Ave., Kyiv, 03037, Ukraine 


\section{MAIN CONTRADICTION OF RELATIONS AT CONSUMER MARKETS AND WAYS OF ITS OVERCOMING}

\section{Khyzhniak V. O.}

\section{INTRODUCTION}

Adequate representation of inward nature of economic contradictions is only one of the tasks of the economics. As the final result the most probable ways of optimal settlement of existing economic contradictions shall be found on the basis of consensus in parties' interests. But when the interests of economic entities become directly antagonistic the task of the science is to develop proposals, measures and specific mechanisms of their practical settlement on the basis of overcoming a confrontational component of the existing contradictions.

Among urgent problems of the current social and economic development of Ukraine one of the most acute issues is the safety of end-consumer goods for health of population. Its resolving in practice not only will mean the increased quality of life on the basis of implementation of the European high standards but also will affect the qualitative characteristics of social rehabilitation and assurance of social stability and national security.

The above-mentioned is directly affected by solutions that shall be found for the wide range of tasks. A strategic problem is that the state's social and economic policy shall be directed on undermining the base of antisocial interests and motivations which provoke confrontational intensification of the main contradiction of relations between consumer marketers. It is means the removal of any opportunities of formation and implementation of incentive motivations for businesses to maximize their profits by socially dangerous violations of necessary safety regulations or standards applied at the market of vital goods (first of all, food products, beverages and goods for children) that is all things which directly affect the state of health, duration of life and reproductive abilities of people. Finally, all this is one of the main factors which induce the large-scale depopulation of Ukraine and as such requires the government policy directed on introducing and ensuring an effective and functional, multilevel and developed system of mechanisms and measures that guarantee the compliance with the established standard consumer rights and are directed on enhancing economic, legal and socially ethical responsibility of businesses for safety of produced and marketed consumer goods. 


\section{Review of research studies and publications}

It should be noted that various aspects of research studies of essence, roles, tasks and features or forms of manifestation of protection of consumer rights on safety consumption by population have been examined in works of known foreign (P. Drucker ${ }^{1}$, P. Kotler ${ }^{2}$, R. Hirst ${ }^{3}$, J.-J. Lambin ${ }^{4}$, G. Cross ${ }^{5}$, P. Stearns ${ }^{6}$ and others) and native (O. Yazvinska ${ }^{7}$, S. Gerasimova ${ }^{8}$, L. Halat ${ }^{9}$, T. Horodets'ka ${ }^{10}$, T. Kahal ${ }^{11}$, T. Kysil'ova ${ }^{12}$, L. Ivanenko, O. Dzera ${ }^{13}$, A. Mazaraki, L Nikolaieva, N. Prytuls'ka, L. Ivanenko ${ }^{14}$, V. Seleznev ${ }^{15}$, V. Martsyn ${ }^{16}$ and others) researchers and economists.

1 Drucker P.F. Management. Tasks. Responsibilities. Practices. New York: Harper \& Row, 1974. -839 pp.

${ }^{2}$ Kotler P. What consumerism means for marketers // Harvard Business Review, 50(3). 1972. - May-June. - P. 48-57; Kotler P. Basis of marketing. - M., 1991.

3 The consumer society / R.C. Hirst, R.W. Duncan - London: Tavistock Publication, 1977. $-269 \mathrm{pp}$.

${ }^{4}$ Lambin J.-J. Marketing strategique et operationnel: Du marketing a rorientationmarche / J.-J. Lambin, R. Chumpitaz, Ch. Moerloose. - Paris: Dunod, 2005. - 718 pp.

${ }^{5}$ Cross G. An All-Consuming Century: Why Commercialism Won in Modern America. New York: Columbia University Press, 2002. - 256 pp.

${ }^{6}$ Stearns P.N. Consumerism in World History: The Global Transformation of Desire. New York: Routledge, 2001. - 160 pp.

${ }^{7}$ Yazvinska O.M. History of consumerism: Work-book $-2^{\text {nd }}$ rev. and corr. ed. - K.: Kyiv Nat. Comm. and Econom. University, 2003. (in Ukrainian)

${ }^{8}$ Gerasimova S.V. Generalization of approaches to determination of consumerism as an economic category // Actual problems of economics. - 2005. - No. 12. - P. 76-79. (in Ukrainian)

${ }^{9}$ Halat L.M. Problems of protection of consumer rights: the Ukrainian realia // Tauric Scientific Bulletin - Kherson, 1998. - Issue 8. - P. 133-140. (in Ukrainian)

${ }^{10}$ Horodets'ka T.N. Economic and legal mechanism of protection of consumer rights // Social priorities in the transition economy: Coll. of sci. and research articles - Kh., 1999. P. 194-198. (in Ukrainian)

${ }^{11}$ Kahal T. For consumers - reliable legal guarantees // Viche.1999. - No. 2. - P. 116-124. (in Ukrainian)

${ }^{12}$ Kysil'ova T.M. Activities of Derzhstandart of Ukraine in the field of protection of the Ukrainian consumer rights. Struggle with violations in the field of production and trade // For the Government of Ukraine, President, legislation and executive authorities: Analytic developments, proposals of research and pract. workers: Coll. - K., 1999. - Vol. 12. P. 552-557. (in Ukrainian)

${ }^{13}$ Ivanenko L.M., Dzera O.V. Peculiarities of indemnification of losses inflicted on buyers due to acquisition of low-grade goods // Small business and management in Ukraine (public and private principles): Coll of sci. and res. art. K., 1997. - P. 195-202. (in Ukrainian)

${ }^{14}$ Protection of consumer rights: social and legal aspect / Kyiv National Commercial and Economic University; A.A. Mazaraki, O.M. Yazvinska, L.V. Nikolaieva et al. - K.: KNTEU, 2002. - 311 p. (in Ukrainian)

${ }^{15}$ Seleznev V.V. How should your consumer rights be defended? - Kh.: Odyssey, 2005. 416 p. (in Russian)

${ }^{16}$ Martsyn V. Consumer is a central person in market relations // Economy of Ukraine. 1996. - No. 3. - P. 83-85. (in Ukrainian) 
The researchers showed great consideration to a general qualitative estimation of the consumerism as a systemic social phenomenon and an economic mechanism of protection of consumer rights. The researchers also conducted solid studies of the history of development of consumerism and its structural components in various countries of the world in the context of the examination and settlement of wide range of complex problems related to the protection of consumer rights and interests in Ukraine and in the world.

At the same time a wide range of problems remains unsolved. First of all it concerns profound scientific understanding the causes that give rise to the actually existing polarity of motivations and interests of consumer marketers and, under certain circumstances, result in the emergence of antagonistic features of existing economic contradictions during their interactions.

The main factors that intensify the generation and growth of actual risks for the population due to production and distribution of goods which are dangerous for human health and life, first of all, the goods of food groups.

Also there is a necessity to develop and implement the effective business and institutional measures and mechanisms for overcoming the confrontational and dangerous contradictions of consumer marketers' interests on the basis of the fullest use of the world experience, objective appraisal of the state of affairs in the domestic market, the fullest consideration of interests of the population and enhancement of social, economic and legal liabilities of businesses.

Therefore the goal of this article is a justification of theoretical and methodological as well practical and applied measures for overcoming the confrontational nature of the main contradiction of consumer marketers' interests in the way to implementation of the policy of social protection and enhancement of efficiency of the mechanisms of assurance of the consumer rights, first of all, the rights for goods and services that are safe for health and life.

\section{Exposition of main content}

By signing the Agreement of Association between Ukraine, as one Party, and the European Union and its member-states as the other Parties (that was ratified by the Verkhovna Rada of Ukraine in September 2014) our state has undertaken liabilities to ensure a high level of protection of the consumer rights and attain the required compatibility of the systems of consumer rights protection in Ukraine and the EU. First of all, it concerns to implementation of the social and economic policy of introduction of high standards of business responsibility (which are currently in force in the EU) into the consumer domain.

Alongside with this problem the important task of the state economic policy is a formation of the most favorable conditions for liberalization of 
business activities. Nevertheless, it should be admitted that the emphases and priorities used in the process of implementation of the current economic policy with regard to simplification of business environment are not always based on the principles of compliance with the requirements for maintaining the adequate safety of consumption by the population. Today this becomes apparent as the neglect of increased threats that really exist in the domain of end-consumption in performing the measures for simplification of business environment, first of all, the existence of criminal actions from the part of businessmen during production and distribution of goods that are unsafe for the health of population, (primarily food groups).

Under conditions of market relations the high consumer-related properties is a base of products and services competitiveness on both domestic and external markets and the guaranteed consumption of qualitative goods (the benefits of life) rises the level of living standards and ensures satisfaction of their various needs that are the base of comprehensive and harmonic development of personality and extended reproduction of human capital. Just therefore the Constitution of Ukraine (art. 50) guarantees the protection of consumer rights, in particular, the rights of citizens for environment that is safe for health and life, and the free access to information about the state of environment, quality of food products and household goods and the right for its distribution.

\section{Causes of the confrontational intensification of the main contradiction of the consumer market}

The main contradiction of relations at the consumer market not only occurs due to discrepancy of interests but is a consequence of the absolute antagonism of interests of principal marketers (businessmen, producers or distributors, on the one part and population, end-consumers of the benefits for life on the other part) at all. That is the essence of the contradiction is an absolute difference in the subject matters of incentive motivations of capitalist market entities as the producers and distributors strive for maximum personal profits but the population strives for satisfaction of personal needs by consumption of goods and services that are safe for health and life.

A main and very dangerous feature of the process of marketing of goods for life is a potential transformation of the above-mentioned contradiction into antagonism as a result of its intensification under possible conditions of the absolute breach of parity and equivalency of relations between market entities due to irresponsible, uncontrolled and non-punishable prevalence of private interests on the part of businesses.

This phenomenon that is founded on the deep-laid and unrestricted by high moral principles aspiration of the capital for maximum profits was 
explained by the British journalist Danning T.J. in his article 'Trades' unions and strikes' published in London as long ago as in 1860. As far back as at the early stage of the development of capitalist mode of production the author affirmed that 'the capital is afraid of lack of profits ... if the profit is sufficient the capital becomes audacious ..., at 50 per cent it is positively ready to break its neck, at 100 per cent it violates all human laws, at 300 per cent there is no such a crime for which it will not venture even under penalty of hanging, ${ }^{17}$.

The historical experience of development of the countries with the civilized market economy indicates irrefutably that when the state is inactive and the institutions of civil society are weak the business, in chase of superprofits, constantly violates the ethics of market relations, first of all by producing and proposing low-grade and unhealthy consumer products. Such a state of affairs existed even in the countries with the advanced market economy at the beginning of the second half of the twentieth century at the latest.

Businessmen realize their aspirations for higher profits not always by legitimate means and very often they can act contrary or even to the detriment of consumer's needs and interests. Just for this reason the state and the civil society shall establish standing and effective systems for accounting and controlling production and mediatory market activities and ensure the implementation of a social and economic policy directed on formation and putting in order the corresponding mechanisms that strictly support economic and legal feedback in relations between market entities. That is such mechanisms whose actions ensure the significant influence of a wide circle of consumers on the motivational behavior of businessmenmanufacturers to guarantee the proper quality of sold goods and services.

\section{Development of the state policy and strengthening the effect of the mechanism of social and economic protection in the way of overcoming the main contradiction of relations on the consumer market}

Under conditions of present-day changes that take place at the global level the state's capability to ensure the actual effectiveness of the its own economic, social-economic or social policy comes up to the higher level of urgency. The state policy shall result in the fullest achievement of the specified both strategic and tactical goals. However, the concept of policy effectiveness shall not be restricted by the capability to implement adopted decisions by the state machinery that performs specific tasks of routine nature. In opinion of Ya. Zhalylo the prerequisites of efficiency of the state policy shall ensure the state's capability to perform tasks designed to affect

\footnotetext{
${ }^{17}$ Dunning, T. J. Trades’ Unions and strikes. London, «Quarterly Reviewer», 1860. - P. 35-36.
} 
social and economic processes, maintain certain priorities and neutralize potential risks with the use of levers of the market economy ${ }^{18}$.

Dialectic of life insistently indicates that the two components of the economic and social-economic policy shall be strictly and optimally implemented: on the one hand, the liberalization of business environment to contribute to simplification of requirements for conducting business activities, on the other hand, the continuous improvement of measures and mechanisms that strengthen business responsibility for the environment that ensures the real safety of end-consumption for the population.

The functional assignment of the social and economic policy is political coordination and regulation of a wide spectrum of social and economic relations which the state carries out on the principles and in the interests of all people of the country or in the interests of social groups and classes that rule and dominate in the state. In substance, the state's social and economic policy is a totality of scientifically formulated ideas, provisions and conceptual approaches (of both the long-term strategic and short-term tactical nature) which combine with a system of specific actions and mechanisms and with the use of which the conscious and competent regulation of social and economic processes is practically performed with due account of mechanisms of market and natural self-regulation.

The state policy of social and economic protection of consumer rights is an important component of the social and economic policy. Realization of this important part of the social and economic policy is carried out by means of functioning (with various levels of efficiency) of the mechanism of social and economic protection of consumer rights.

In substance and by implication this mechanism is a complex system of interrelated economic, social, legal, organizational, business, organizational and social, social and legal, ethical and moral measures, actions, levers, tools, economic and legal sanctions, incentives and social motivations which are used by the state to overcome the confrontational nature of the main contradiction of relations on the consumer market. This task is fulfilled at various institutional levels (an enterprise, firm, civil society) and ensures the implementation of the legally established rights of end-consumers to qualitative and safe satisfaction of life needs that are required not only for the simple but also for expanded human reproduction both on the familyindividual and on the social levels.

\footnotetext{
${ }^{18}$ Agreement of Association between Ukraine and the EU. Section V. Chapter 20 «Economic and sectoral cooperation» P.5 [Electronic resource]. - Access mode:. http://zakon2.rada.gov.ua/rada/show/984_011
} 
The mechanism of social and economic protection of consumer rights is multifunctional and systemic-structured and comprises the components shown in a scheme (Fig. 1).

The mechanism of ensuring quality and safety of end-consumer goods is an internal-systemic component of the general mechanism of social and economic protection of consumer rights.

This internal-systemic mechanism is also a multifunctional (with a various level of efficiency) system of actions, tools and sanctions which are used to form motivational prerequisites and exert direct and incentive influence on manufacturers and market agents by means of securing the application of corresponding quality regulations and standards of products, procedural measures of their certification, supervision and monitoring production processes, compliance with the requirements for licensing of business activities and securing the corresponding terms of marketing of these products to end-consumers.

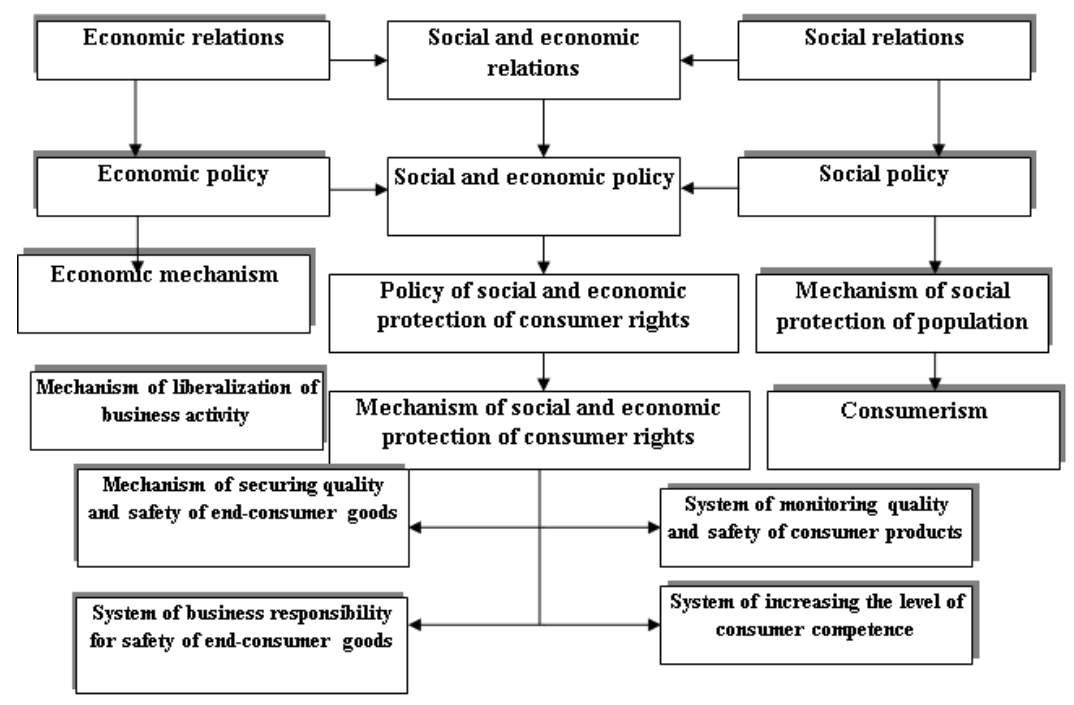

Fig. 1. Scheme of systemic interconnections and interactions of the social and economic policy the mechanism of social and economic protection and its systemic components (author's design)

Mechanism of ensuring quality and safety of end-consumer goods at the individual and social levels shall secure the realization of the guaranteed right of people to consume qualitative benefits and services which they get 
in the process of market exchange (from manufacturers, specialized sellers and private persons who have right to produce and sell consumer goods). The mechanism acts on the principles of binary combination of two organizational components: the state and the civil society. It gives an opportunity to overcome the main contradiction of relations on the consumer market.

The following systemic components are also important factors for overcoming the antagonistic nature of the contradiction: 1) a system of monitoring the quality and safety of consumer products; 2) a system of business responsibility for safety of end-consumer goods; 3) a system of increasing the level of consumer competence of the population. The content of these systemic components requires special consideration.

\section{Basic stages of cardinal transformation of the state policy of protection of consumer rights in Ukraine}

Three basic periods that characterize the priorities of the state policy and, accordingly, the actual state of protection of consumer rights in Ukraine may be singled out.

1. Period 1991-2001 may be considered as rather contradictory. On the one hand, just in the same period the state promotes the accelerated formation of a branched regulatory and legal framework for protection of consumer rights in the market of goods and services in the country's legislation field. Today the system comprises eight laws and thirteen bylaws $^{19}$. Therefore, at first sight it seems that this legal system shall function rather reliably and protect the interests of end-consumers efficiently. On the other hand, just in the same period a significant institutional weakening of the control over low-grade and unsafe goods took place. First of all, this situation occurs due to unsystematic demolishing of the old control system and inadequate functioning of a new control system given threats of existed large-scale corruption.

In this period a rather branched and sufficiently effective state system for controlling low-grade goods existed in Ukraine. First of all, this system comprises the powerful service of sanitary and epidemiological control of the Ministry of Health as well as the products certification bodies of Derzhstandart and other ministries and departments that have not been liquidated earlier and the control bodies of Derzhspozhyvzahyst. In particular, the system of state certification of Ukraine comprised 138

\footnotetext{
${ }^{19}$ Mandybura V.O., Khyzhniak V.O. Problems of ensuring the adequate economic responsibility of business for violations of consumer rights // Scientific transactions of the Institute of Legislation of the Verkhovna Rada of Ukraine. - 2017.- No. 5. - P. 74-90 (in Ukrainian).
} 
accredited bodies, 17 ministries and departments. About 680 test laboratories for 32 product types functioned in this system.

Just during the first stage when the monitoring and, in particular, laboratory and research base was reducing the most dangerous threats for consumers were established and up to date these threats remain topical.

The production of bakery products became unsafe for domestic consumers due to the use of various food synthetic additives which had not been approved by the MOH of Ukraine. In particular, there were cases when metaphos, a highly toxic substance, was detected in bread and metaphos decomposition products were detected in raw materials.

The campaign for 'deregulation' of the economy that was started in this period resulted in the state when business entities which had passed the official procedure of registration could start the production of products without the corresponding technical or technological qualification and any normative documents and the legislation in force did not forbid them to do so. This resulted in growth of large-scale violations of consumer rights, in particular, the right to health.

The situation became especially unsafe due to reduced attention paid to proper quality and safety of infant food products. Non-availability of reliable and necessary information about goods and possibility of selling infant food products without certificates of conformity and with elapsed expiration dates were among large-scale violations. As a rule, the quality control of consignments of infant food products supplied in Ukraine under contracts with foreign partners was not comprehensive. In particular, very often the date of production was not indicated on the manufacturer identification label, only the month and year of production. As a result, the identification of a specific consignment of products with the use of the document that confirmed their proper quality became impossible.

Just in this period businessmen began to apply the unsafe for health synthetic additives during production of food products on a large scale.

Color additives (for imparting attractive colors to food products), unsafe ones: E110, E123, E127, E129, E150, E151, E173-175; conserving agents (for prolonging shell lives of food products before consumption), unsafe ones: E210, E212, E216-219, E227, E228; antioxidants (for retarding oxidation, inhibit spoilage of foods, are similar to conserving agents by their action), unsafe ones: E330; E339-341; stabilizers (for maintaining the specified consistency of food products), unsafe ones: E400-403, E450-452; emulsifiers (for maintaining a certain structure of good products, are similar to stabilizers by their action), unsafe ones: E521-523, E541-556, E559, E574-579; flavor intensifiers, unsafe ones: E620-625; 
2. Period 2001-2011 may be considered as the most effective for strengthening the protection of consumer rights, first of all, by raising requirements for quality and safety of food products.

First of all, this period may be considered as the most active time as regard to strengthening the effective checking of manufacturers and market agents for quality of products by the corresponding authorities for protection of consumer rights.

Also some positive moments in the functioning of the state authorities for protection of consumer rights on the market of end-consumer goods and services may be highlighted. These actions were directed on development and active reviewing of interstate standards developed before 1992 that were in force in Ukraine at that time. This work was carried out in accordance with the Program of bringing them in accordance with the Agreement on technical barriers in trade with the World Trade Organization and harmonization with the European model of standardization.

Main directions in implementation of the above Program were as follows:

1) reviewing the interstate standards for compliance with the legislation, interests of the state, consumer needs, levels of development of science and technology, requirements of international and regional standards, position of the Agreement on technical barriers in trade; 2) reviewing the interstate standards and making changes in them or replacing them by the corresponding international or national standards; 3) withdrawing the interstate standards that ceased to be topical, were not used and didn't comply with the current legislation.

The intermediate index of performing the Program for that period was as follows: as on 29.12.2007 4565 national standards that had been harmonized with the international or the European once were in force in Ukraine.

3. Period from 2012 to the present time is a period of significant weakening of the level of protection of consumer rights. The actual practice shows that after the period of the intensified effective checks of goods quality the state authorities for protection of consumer rights abruptly decreased the number of checks in pursuance of the keynote on prevention of corruption and in compliance with the requirement for 'maximum liberalization of business activities'. Therefore the number of recorded cases of criminal violations of consumer rights was reduced accordingly.

However, at the present time the domestic corruption heads all world records ${ }^{20}$ and criminal offences in the field of violations of consumer rights and manifestations of negative consequences of these crimes for the

\footnotetext{
${ }^{20}$ Mandybura V.O. Corruption: institutional essence and mechanisms of overcoming / monograph. - K.: Parliament Publ. House, 2017. - P. 488 (in Ukrainian).
} 
population continue to rise. Even at the official level this situation is considered as extremely unsatisfactory. Thus the Concept of the state policy in the field of protection of consumer rights for the period up to 2020 clearly states that «the consumers in Ukraine are not protected by the state and the law due to the declarative nature of the declared rights and lack of mechanisms of their implementation and recommencement'. The lack of complete system of the state supervision (monitoring) results in creation of competitive advantages for unscrupulous businesses. Thus the domestic consumer market is more risky for consumers and violations of their rights occur on the large scale. Majority of economic entities (manufacturers) lose their competitiveness both inside the country and in the common with the EU market. The spread of unsafe products and low-grade products in the domestic market becomes more dangerous for health and life of the population $^{21}$.

Just therefore the Concept specifies '.. harmonization of the system for protection of consumer rights in Ukraine with the principles, approaches and practices of the EU; protection of the constitutional guarantees of consumption safety and quality ...; improvement of efficiency of the system for protection of consumers against unsafe products which can harm the life, health or property of consumers, the environment including efficiency of the state market supervision' as one of the most important tasks.

\section{Elimination of inadequacies and economic responsibility of business for violation of consumer rights in overcoming the main contradiction}

The important direction of actions for liquidation of antagonistic manifestations of the main contradiction of the consumer market is the improvement of the system of adequate responsibility of business for safety of end-consumer goods, in particular, it concerns the evaluation of real capabilities of the existing regulatory and economic framework to ensure the adequate responsibility of businesses in cases of fraudulent or counterfeited violations of the regulated norms and standards of quality and safety of marketed benefits for life, whose consequences directly affect the health state and duration of life of people.

The basic economic sanctions for particular violations of consumer rights are regulated by Article 23 of the Law of Ukraine «On protection of consumer rights».

The old ways to deceive buyer or customers are as follows: cheating in measuring, weighing, or counting. The modern negative practice includes a

\footnotetext{
${ }^{21}$ Concept of the state policy in the field of protection of consumer rights for the period of up to 2020 approved by the Decree of the Cabinet of Ministers of Ukraine dated March 29, 2017 No/ 217-r. Ukraine [Electronic resource]. - Access mode: zakon.rada.gov.ua/laws/ show/217-2017 (in Ukrainian).
} 
wider spectrum of other 'up-to-date' manifestations of deceptions of consumers. In particular it concerns all such manifestations of fraudulent falsifications of declared consumption quality of marketed low-grade and unsafe for life and health goods, first of all food products and beverages including spirits. The structural analysis of letters-appeals of citizens at the address of Derzhspozhyvstandart (State agency of consumption standards) of Ukraine confirms the above and shows that ' 42 per cent of consumers complain of low-grade or counterfeited goods, first of all food products (meat and milk, bakery, confectionery products, drinking water and spirits and tobacco goods) ${ }^{, 22}$.

It is important to say that the personal aspect of crimes related to the violations of people rights to consume the products which are safe for health and life is characterized by just the deliberate form of incentives by which a business entity is guided when he (or she) commits a crime that defines his (her) guilt. At the same time due to lobbying efforts Article 225 was withdrawn from the Criminal Code of Ukraine. This article provided for strengthening the responsibility for repeated offences that were committed by a person who had been earlier convicted for deceits of buyers or customers and inflicted $a$ penalty at the rate of one hundred to five hundred of the tax-free minimum income of an individual or putting under restraint for the term of up to three years. (Note: is should be said that in the USA the money equivalent of the restraint for three years is a sum of recovery from 10,000 to 50,000 USD. To compare, in Ukraine the above term of restraint corresponds an absolutely scanty and inadequate sum in UAHs that is an equivalent of 325 USD. Given the exchange rate this sum equals 500 taxfree minimum incomes of an individual specified in the national legislation!!!)

All above-mentioned allow us to make a conclusion that the economic responsibility of business for violations of consumer rights, which is defined by the universal measure that is currently in force and equals a certain number of 'the regulatory tax-free minimum income of an individual', may be considered as not only inadequate but pitiful and trifling at all.

The tax-free minimum income of an individual was approved by the legislation at the level of $17 \mathrm{UAH}$ in 1995. Up to the present it was not reviewed at all. But for the period from 01.10.1995 to 01.12.2017 the price inflation index at the consumer market as well as the exchange rate $\mathrm{USD} / \mathrm{UAH}$ increased by more than order. If at the moment of approval of the tax-free minimum the exchange rate USD/UAH used as a basic value was 1.7:1.0, now it exceeds $26: 1$. The above shows that for the 22 year period the

\footnotetext{
${ }^{22}$ Protection of consumer rights in Ukraine [Electronic resource]. - Access mode: www.radiosvoboda.org/a/1984258.html (in Ukrainian).
} 
inflationary depreciation of the purchasing power of hryvnia is 15.3 times and the tax-free minimum itself has decreased from the equivalent level of 10 USD down to a scanty equivalent that now does not exceed 65 cents.

The above-mentioned indicates that as for today all regulatory economic sanctions for manifestations of criminal violations of consumer rights, which are calculated in the regulatory specified number of 'the tax-free minimum income of an individual', are absolutely pitiful and trifling (as it was mentioned earlier) from the economic point of view of an adequacy of the sanctions in force.

First of all, the performed analysis indicates the inadmissibility of further application of the tax-free minimum income of an individual as a regulatory basic value for determination of an economic sanctions volume for criminal violations of consumer rights because their aggregate cost values are scanty under current economic conditions.

The author's proposal to increase adequate economic responsibility of business consists in the necessity of urgent introduction of a new universal regulatory base value into the domestic practice. This value is a scale-fixed cost that is determined on the principles of application of the indices of the income base of the consolidated government budget. The value shall be fixed if expressed in hryvnias and valid within the current year.

A The regulatory base value shall be established by means of implementation of three basic principles:

1) to provide inflatory neutrality of the scale cost value of index by using an objective and high-quality scientifically based method of its determination;

2) to provide social justice that is to eliminate any possibility of further use of existing social and economic norms such as minimum wages, lower income limit, living wages, tax-free minimum incomes of individuals and others;

3) to eliminate lobbying and corporative interests, possibility of their realization in practice by means of selfish - motivated influence both on the process of objective and adequate determination of the value of regulatory base index and barring of its regular reconsideration.

The method of calculation of the regulatory base value provides its determination as one billionth of an average value of the income part of the consolidated budget of Ukraine taken for the three previous years before the year of approval of a budget for the next fiscal year.

Example:

1. If in 1995 the income part of the consolidated budget of Ukraine was 20,689.9 bln UAH; in 1996 - 30,218.7; in 1997 - 28,112.0 bln UAH, then the regulatory base value that should be approved for 1999 shall be 26.3 UAH (not $17 \mathrm{UAH}$ ). 
2. If in 2007 the income part of the consolidated budget of Ukraine was $219,936.5$ bln UAH; in 2008 - 297,893.0; in 2009 - 272,967.0 bln UAH, then the regulatory base value that should be approved for 2011 shall be 263.6 UAH (not 17 UAH).

3. If in 2014 the income part of the consolidated budget of Ukraine was ....... bln UAH; in 2015 - ........ bln UAH; in 2016 - ....... bln UAH, the regulatory base value that should be approved for 2018 shall be established at the level of ....... UAH (not 17 UAH).

The regulatory base value shall be calculated and approved by the Verkhovna Rada of Ukraine every year together with the approval of the budget of Ukraine for the next fiscal year in which this value shall be used.

For the purpose of adaptation of market entities to a new level of the regulatory base value a four (4) year transition period may be provided: during the first year the norm of $25 \%$ of the regulatory base value shall be applied; during the second year $-50 \%$; during the third year $-75 \%$. Beginning from the fourth year the norm of $100 \%$ shall be applied.

Thus, the proposed mechanism can be used for conducting the annual indexation of the regulatory base value for the purpose of complete and unbiased accounting of the dynamics of existing inflatory process and changes in the GDP (growth or drop) and excluding any actual decrease in the cost value of this index down to an inadmissible level.

\section{CONCLUSIONS}

Under conditions of the process of integration with the EU Ukraine undertakes to ensure a high level of protection of consumer rights, first of all, to introduce the high standards of product safety that are currently in force in Europe and to ensure the adequate economic, legal, ethic and moral responsibility of businesses for violations of consumer rights.

Antagonistic contradictions of relations on consumer markets originate as a result of opposite interests of major market entities: on the one hand, businessmen-manufacturers and businessmen-distributors, on the other hand, the population or end-consumers of benefits for life. These contradictions are conditioned by the aspiration of businesses for maximum personal profits for any price, even for the sake of people's interests while the population strive for satisfaction of personal needs in consumption of goods and services that are safe for health and life.

The important political directives of compliance with maximum liberalization of business activities and prevention of corruption shall not be implemented by means of weakening the level of protection of domestic consumer rights and abandoning the monitoring functions of the state. On the national arena the state policy shall be directed at the ceaseless 
implementation of the European integration concept of «the absolute responsibility of manufacturers» for the quality and safety of produced and distributed goods.

On the way to overcoming the main contradiction of relations on consumer markets the mechanism of social and economic protection of consumer rights is instrumental. This mechanism is a complex system of interrelated economic, social, legal, organizational, economic-organizational, social-organizational, social-legal, ethic-moral measures, actions, levers, tools, economic and legal sanctions, incentives and social motivations which are used by the state in overcoming the antagonistic contradiction of relations on consumer markets. The specified task is fulfilled at various institutional levels (an enterprise, firm, civil society) and ensures the implementation of the legally established rights of end-consumers to qualitative and safe satisfaction of life needs that are required not only for the simple but also for expanded human reproduction both on the familyindividual and on the social levels.

Recording under domestic conditions of numerous manifestations of fraudulent falsifications of declared consumer quality in the process of marketing low-grade and unsafe for life and health goods, first of all, food products and beverages including spirits, demands strengthening and irreversibility of legally specified economic sanctions for criminal violations of consumer rights. There is a necessity to reject the practice of determination of the amount of penalty sanctions in terms of the specified number of 'tax-free minimum income of an individual' as from the economic point of view such a penalty is absolutely inadequate, pitiful and trifling as compared with losses inflicted on consumers. Just for this reason the further use of the tax-free minimum income of an individual as a basic cost value for determination of the amount of economic sanctions for criminal violations of consumer rights is inadmissible.

The author's proposal consists in the introduction of a new regulatory base value into practice. This value features inflatory stability as it is a scalefixed cost that is determined on the principles of application of the indices of the income base of the consolidated government budget. The value shall be fixed if expressed in hryvnias and valid within the current year. The bases and content of the method of calculation of the regulatory base value are described in the article.

\section{SUMMARY}

Consumer marketers' motivations and interests causing antagonistic contradictions have been considered. Main factors that lead to increased actual threats to population due to production and distribution of goods which are unsafe for human life and health, in particular, food group, have 
been established. Salient features of the process of formation of the institution of confidence on the basis of interactions between the institutions of consumerism and marketing have been demonstrated by using the countries with advanced market economy as an example. Stages and main indices of the process of implementation of the policy of protection of interests of consumer marketers have been characterized. Dangers of implementation of the policy of business liberalization at the expense of curtailment of mechanisms of consumer right protection and securing irreversible legal and economic liabilities of businesses for quality and safety of end-consumer goods have been confirmed. The ways of settlement of antagonisms at the consumer market by implementation of effective mechanisms of strengthening the adequate responsibility of businesses in cases of criminal or fraudulent violations of consumer rights and noncompliance with the requirements for goods to be safe for human health and life have been demonstrated.

\section{REFERENCES}

1. Drucker P.F. Management. Tasks. Responsibilities. Practices. New York: Harper \& Row, 1974. - 839 pp.

2. Kotler P. What consumerism means for marketers // Harvard Business Review, 50(3). - 1972. - May-June. - P. 48-57; Kotler P. Basis of marketing. - M., 1991.

3. The consumer society / R.C. Hirst, R.W. Duncan - London: Tavistock Publication, 1977. - 269 pp.

4. Lambin J.-J. Marketing strategique et operationnel: Du marketing a rorientationmarche / J.-J. Lambin, R. Chumpitaz, Ch. Moerloose. - Paris: Dunod, 2005. - 718 pp.

5. Cross G. An All-Consuming Century: Why Commercialism Won in Modern America. - New York: Columbia University Press, 2002. - 256 pp.

6. Stearns P.N. Consumerism in World History: The Global Transformation of Desire. - New York: Routledge, 2001. - 160 pp.

7. Yazvinska O.M. History of consumerism: Work-book $-2^{\text {nd }}$ rev. and corr. ed. - K.: Kyiv Nat. Comm. and Econom. University, 2003. (in Ukrainian)

8. Gerasimova S.V. Generalization of approaches to determination of consumerism as an economic category // Actual problems of economics. 2005. - No. 12. - P. 76-79. (in Ukrainian)

9. Halat L.M. Problems of protection of consumer rights: the Ukrainian realia // Tauric Scientific Bulletin - Kherson, 1998. - Issue 8. - P. 133-140. (in Ukrainian) 
10. Horodets'ka T.N. Economic and legal mechanism of protection of consumer rights // Social priorities in the transition economy: Coll. of sci. and research articles - Kh., 1999. - P. 194-198. (in Ukrainian)

11. Kahal T. For consumers - reliable legal guarantees // Viche.1999. No. 2. - P. 116-124. (in Ukrainian)

12. Kysil'ova T.M. Activities of Derzhstandart of Ukraine in the field of protection of the Ukrainian consumer rights. Struggle with violations in the field of production and trade // For the Government of Ukraine, President, legislation and executive authorities: Analytic developments, proposals of research and pract. workers: Coll. - K., 1999. - Vol. 12. - P. 552-557. (in Ukrainian)

13. Ivanenko L.M., Dzera O.V. Peculiarities of indemnification of losses inflicted on buyers due to acquisition of low-grade goods // Small business and management in Ukraine (public and private principles): Coll of sci. and res. art. K., 1997. - P. 195-202. (in Ukrainian)

14. Protection of consumer rights: social and legal aspect / Kyiv National Commercial and Economic University; A.A. Mazaraki, O.M. Yazvinska, L.V. Nikolaieva et al. - K.: KNTEU, 2002. - 311 p. (in Ukrainian)

15. Seleznev V.V. How should your consumer rights be defended? - Kh.: Odyssey, 2005. - 416 p. (in Russian)

16. Martsyn V. Consumer is a central person in market relations // Economy of Ukraine. - 1996. - No. 3. - P. 83-85. (in Ukrainian)

17. Dunning, T. J. Trades' Unions and strikes. London, «Quarterly Reviewer», 1860. - P. 35-36.

18. Agreement of Association between Ukraine and the EU. Section V. Chapter 20 «Economic and sectoral cooperation» [Electronic resource]. Access mode:. http://zakon2.rada.gov.ua/rada/show/984_011

19. Mandybura V.O., Khyzhniak V.O. Problems of ensuring the adequate economic responsibility of business for violations of consumer rights // Scientific transactions of the Institute of Legislation of the Verkhovna Rada of Ukraine. - 2017.- No. 5. - P. 74-90. (in Ukrainian)

20. Mandybura V.O. Corruption: institutional essence and mechanisms of overcoming /monograph. - K.: Parliament Publ. House, 2017. - P. 488. (in Ukrainian)

21. Concept of the state policy in the field of protection of consumer rights for the period of up to 2020 approved by the Decree of the Cabinet of Ministers of Ukraine dated March 29, 2017 No/ 217-r. Ukraine [Electronic resource]. - Access mode: zakon.rada.gov.ua/laws/show/217-2017. (in Ukrainian)

22. Protection of consumer rights in Ukraine [Electronic resource]. Access mode: www.radiosvoboda.org/a/1984258.html. (in Ukrainian) 
23. Mazaraki A. Lahytin V. Domestic market of Ukraine under conditions of unbalances between production and consumption // Scientific journal «Economy of Ukraine». - 2016. - No. 4 (653) - P. 4-18. (in Ukrainian)

24. Consumerism. Search for the Consumer Interest. - New York; London, 1974. - P. 6-7.

25. Chevrolet Corvair 1960-1969 - «Dangerous at any speed» [Electronic resource]. - Access mode: www.drive2.ru/b/2639701.

26. Heiets V.M. Interaction of confidence and development / V.M. Heiets// Scientific journal «Economic theory».- 2002. - No. 3. P. 3-16. (in Ukrainian)

27. Zhalylo Ya. Evolution of effectiveness factors of the state economic policy and institutional crisis in Ukraine /Ya. Zhalylo// Scientific journal «Economic theory». - 2015. - No. 2. - P. 5-18. (in Ukrainian)

28. Reports on performance of Derzhprodspozhyvcluzhba [Electronic resource]. - Access mode: www.consumer.gov.ua / ContentPages / Zviti_Pro_Robotu_Derzhprodspozhivsluzhbi/170. (in Ukrainian)

\section{Information about the author: Khyzhniak V. O., Candidate of Economic Sciences, Director of the State Enterprise} «Research Institute of Building Production named of V.S. Balitsky» 51, Lobanovskyi av., Kyiv, 03110, Ukraine 


\section{APPLIED SCIENTIFIC TOOLS OF IMPROVING THE EFFICIENCY OF ECONOMIC ENVIRONMENT OF CONSTRUCTION ENTERPRISES OPERATION IN THE PROJECT DEVELOPMENT SYSTEM}

\section{Ryzhakova G. M.}

\section{INTRODUCTION}

One of the key problems hampering the housing construction development in Ukraine is the lack of investment. The current crisis in the construction area has been caused by investors' mistrust of developers who, having raised funds, substantially violate their obligations. Investors face a limited choice of investment mechanism, tending to invest only in the areas where market players and the state have created proper conditions for business transparency and reliability and property rights protection. A need arises in researching the issues of investment of residential construction, introducing market mechanisms for investing in housing development by attracting external and internal investment resources pursuant to minimizing investors' risks, improving the investment environment and activization of the role of the economy's banking sector.

Recent studies of the described range of problems demonstrate that in the context of the financial crisis, it is necessary to adopt a range of legislative documents to facilitate the construction industry development.

Currently, the theoretical and methodological framework for the coverage of the issues connected with investing into the housing construction by attracting private funds, as well as the choice of the mechanism of investing into housing construction is debated among domestic scientists and experts. The issues of investment activities were researched in the works of such Ukrainian scientists as: I.O. Blank, S.D. Bushuiev [1], N.S. Bushuieva [1], A.F. Hoiko [2], N.O. DotsenkoBilous [3], Z.V. Zadorozhnyi, Ya.D. Krupka, P.M. Kulikov [4], I.P. Otenko, T.S. Marchuk [5], S.P. Stetsenko, V.O. Pokolenko [6], I.V. Popovychenko, M.S. Pushkar, G.V. Ryzhakova [7], T.V. Savchuk, D.O. Chernyshev [8], Yu.A. Chupryna [9], A.S. Fesun [10] and others.

However, despite a large number of researches on this topic exist, a lot of them are of a general descriptive, conceptual nature and does not account certain industrial dimensions of applied financial management, in particular, the definition of the essence of the concept of investment and disclosing the 
features of the organizational procedure of implementing various investment mechanisms in housing construction; the issue of selecting the least risky mechanism of attracting funds to invest into housing construction, as well as each mechanism's place and role in the domestic system of investing into housing construction; adapting western mechanisms of investing into the housing facilities construction to the current environment in which domestic construction companies operate, and their consolidation with domestic methodological and applied best practices in implementing investment and construction projects etc.

The purpose of the present article is providing theoretical and methodological background and applied development of an alternative mechanism of investment into housing construction aimed at expanding the role of investments in the activities of institutional investors - stakeholders of a developer construction project (DCP), which will serve as an additional investment resource for domestic construction companies in the current and future environment and facilitate the increase of DCP investment attractiveness.

\section{Funds trust management in the system of construction funding}

In the market economy, the organization of attracting investment into rather resource-intensive housing construction, is becoming one of the directions of any construction company's areas of activity providing a successful implementation of housing sphere construction projects. This activity gains special importance now, in the context of the financial and economic crisis in Ukraine, when it is necessary to consider the impact of a number of factors on it. First, since the reforms in Ukraine were introduced, the financial standing of construction companies deteriorated, and an acute working capital deficit emerged. Second, the scarcity of working capital was increased due to the rising costs of credits, national currency devaluation and progressing inflation. Third, as Ukraine is still at the early stage of forming a market economy, until recently domestic construction companies were able to use only a limited range of investment attraction mechanisms. A gradual development of market relations has diversified the forms and methods of financing operating assets of the construction companies which transited to independent economic policy formation.

The range of problems of the theoretical framework and practical mechanism of investing into housing construction (fig. 1) as a basic condition of investment support of construction companies' development is one of the most disputed in the modern science. Under the existing circumstances the significance of investment undergoes qualitative transformation. It evolves from a passive distribution mechanism of newly formed value into the main regulator of modern enterprises' economic 
activity. In the economic literature, the definition of the investment mechanism is not yet well established.

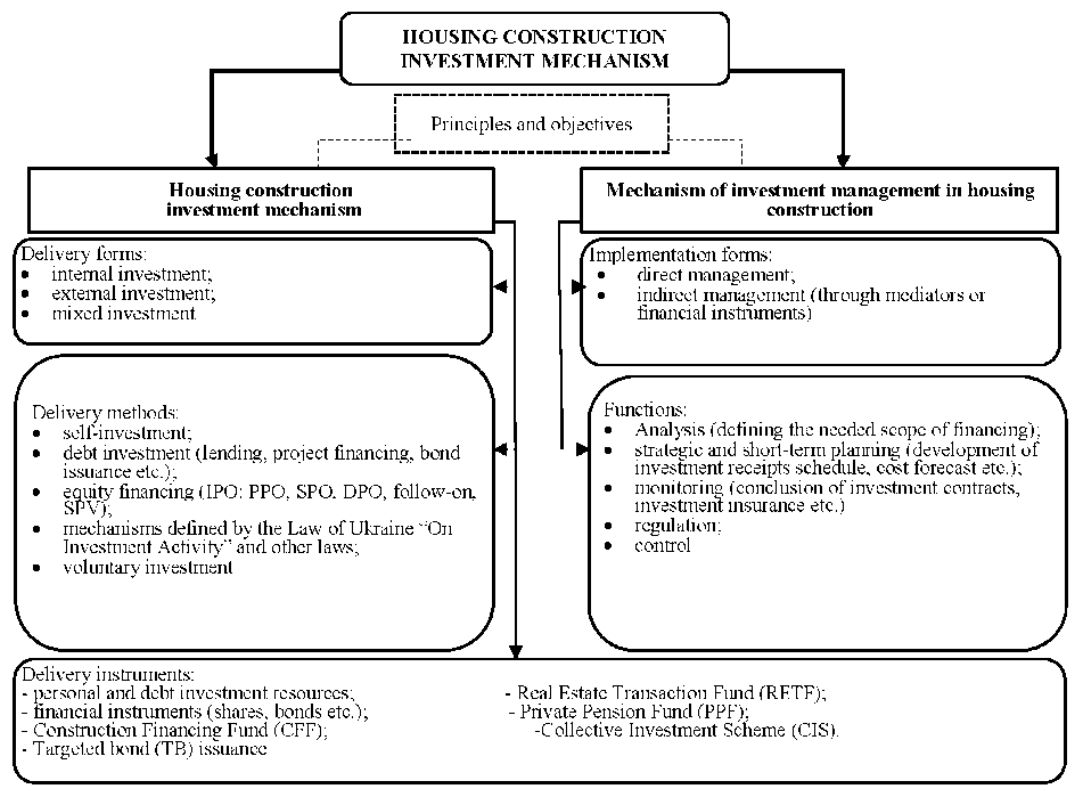

\section{Fig. 1. Component-based structure of the housing construction investment mechanism}

In the legislative environment, the term "housing construction investment" is mentioned in the Law of Ukraine "On Investment Activity" of 18.09.1991 No 1560-XII (as amended), but it defines only the sources of investment activities financing (Article 10). From the standpoint of a construction company, the term "economic activity investment" can be found in the Commercial Code, where it is defined as a "long-term investment of various kinds of property, intellectual assets and property rights in objects of economic activity with the aim of revenue (profit) generation or achieving other social effect." Also, the term "investment activity" is mentioned in the National Provisions (Standards) on Accounting No 1 "General Requirements for Financial Reporting" and means acquisition and disposal of those non-current assets and those financial investments which do not constitute a part of cash equivalents.

The most crucial aspect of investment into construction is the choice of the best depositing mechanisms. Despite having several common features, 
each of them has its specifics which depend on the developer's legal status, financing procedure, documents which are executed, the aim pursued by the parties etc. The list of legal financing mechanisms for housing construction is established by the mentioned Law of Ukraine № 1560-XII. Thus, by virtue of part 3, Article 4 of the Law № 1560-XII, the ways of attracting investments are: - construction financing funds (further-CFF); - real estate transaction funds (RETF); - co-financing institutions (CFI); - special purpose bond (SPB) emissions at enterprises. The same source establishes that other ways of construction financing are defined exclusively by laws. However, despite the express prohibition stipulated by Article 4 of the Law of Ukraine "On Investment Activities", in practice, developers often use socalled "parole investment contract", i.e., contracts on investment (common share in construction financing) and purchase and sale of property rights to real property under construction. Indeed, as the Civil Code of Ukraine accords the right to conclude any kinds of contract not expressly prohibited by the current legislation of Ukraine, a situation can be construed in an ambivalent manner and conclude the mentioned contracts using the provisions of the Civil Code on the freedom of contract. To avoid negative consequences, only legal investment mechanisms should be used which are listed in part 3 of Article 4 of the Law № 1560-XII. So, the choice of a specific way of construction financing becomes key for an investor.

Upon bringing amendments to the legislation on investment activities, the possibility of concluding direct investment contracts for housing construction was excluded, and the list of investment methods was limited only to the mechanisms provided for by Article 4 of the Law of Ukraine "On Investment Activity". As a result of these amendments, a legislative prohibition was imposed on concluding investment contracts in the housing construction sphere and promotion of the cases of using financial mechanisms - housing financing funds and real estate transaction funds provided for by the Law of Ukraine "On Financial and Credit Mechanisms and Property Management during House Building and Real Estate Operations" of June 19, 2003, 978-IV.

The peak of commissioning of houses in the country was registered in 2017, amounting to 5.9 million square meters of commissioned housing. In 2018, the amount of constructed housing in Ukraine declined by $25 \%$, and in the first quarter of 2019, the market shrank by another $4 \%$. Over $30 \%$ of purchases of housing built in Kyiv are conducted under forward contracts, around 20-25\% of developers use property bonds when selling newly built housing, $10 \%$ of housing are sold via construction financing funds (CFF) ${ }^{1}$.

\footnotetext{
1 Housing construction schemes in Kyiv. Electronic resource. Available at:
} http://directinvest.com.ua/ru/2018/05/11/sxemi-finansuvannya-budivnictva-zhitla-v-kiyevi: 
These mechanisms belong to the so-called schemes of investing into purchase. The rest of new buildings in Kyiv are sold via the mechanism of real estate purchase, namely via concluding real estate purchase and sale contracts or property rights purchase and sale contracts.

No consensus exists among researchers of history of jurisprudence as to the genesis of the trust management concept. Most scientists held a general view that trust management stem from the British tradition, of which a special concept of trust as a separate scheme of legal relations is characteristic. The classical Anglo-America form of trust management foresees that a trustee reserves the legal right of title and can use both the respective property and any profit thereon. In contrast to the principles of the orthodox continental law, the British legal doctrine allows for a so-called "splitting" of property, when one object can in fact have two owners - a conventional one and a trust one. The adoption of the Decree of the Cabinet of Ministers of Ukraine "On Trust Institutions" No 23-93 of 17.03.1993 was the first attempt to legalize trust relationships in Ukraine. Legislative uncertainty, the fact that no legal expertise of the draft Decree was held, the lack of a clear system of control of financial intermediaries' activities, irresponsibility of local executive bodies were conductive to the active creation and unlawful activities of pseudo-trust institutions, trusts, insurance companies, investment funds and other business entities acting to attract property and, which is the worst, citizens' money. The fact that no timely preventive measures were taken by authorities, regulatory and lawenforcement bodies led to proliferation in Ukraine of financial fraud on a scale so large it was dangerous for the state, rip-off of the population, chiefly socially vulnerable. In fact, trusts as a tool of trust management were fully discredited by economic realities. Further development of management relations can be divided into two stages: the first one - 1996-2001 - was signified by the creation of the legislative framework for operations on securities management; the second one - 2002-2005 - by the creation of the legislative framework for operations on money management in financial and credit sphere. Specialists were ambiguous as to the introduction of the category of trust property into the Ukrainian legal system. Involving developers in the use of the financial schemes defined by the Law on property management during house building is largely of the nature of regulatory coercion. It is the strict legislative restrictions prompted most developers to introduce the mechanisms of trust management into their work. Considering the legislative ambiguity of the category of trust management characteristic of the domestic legal system, and considering the special character of industry-specific legislation, the term "trust management of property in housing construction" should be defined as a statutorily prescribed (by the Law of Ukraine "On Financial and Credit Mechanisms 
and Property Management during House Building and Real Estate Operations") set of principles, legal and organizational framework for attraction of investor's funds into management based on the enforcement of the trust property right with the aim of housing construction financing. The implementation of trust management of property is provided for by the legislation through the use of CFF mechanisms and attraction of funds to housing construction via the use of securities emitted by the trustee of a real estate transaction fund (RETF). Despite the distinct kinship of these entities, their principal distinction is that trustors buying RETF certificates do not aim to obtain housing. It is worth mentioning that trust management is a separate legal tool different from such categories as management, operational management, and the right of full economic management, which is common in the modern economic use.

The forward contract scheme (table 1) gained special popularity among Kyiv developers 2-3 years ago. A derivative is a standard document certifying the right and/or obligation to purchase or sell, on certain conditions, in future, securities, funds, tangible assets (in our case immovables) or intangible assets. As a rule, when selling immovables in new houses through forward contracts, the agreement is concluded with the participation of asset management company in two stages:

- registration of the forward contract on a commodity exchange;

- conclusion of an contract of purchase and sale of property rights between the parties to the agreement.

Table 1

Key advantages of the forward financing scheme

\begin{tabular}{|c|c|}
\hline For developer & For investor \\
\hline $\begin{array}{l}\text { - allows to organize construction as a } \\
\text { partnership, when one company owns the } \\
\text { site, and the other holds all the permits for } \\
\text { construction; }\end{array}$ & $\begin{array}{l}\text { - allows to avoid the risks of double sales } \\
\text { (investor is granted an exclusive right of } \\
\text { preference in purchasing an apartment under } \\
\text { the contract of purchase and sale of property } \\
\text { rights); }\end{array}$ \\
\hline $\begin{array}{l}\text { - when working with forward contracts, a } \\
\text { developer needs no manager, as is the case } \\
\text { with using construction financing funds; }\end{array}$ & \multirow{2}{*}{$\begin{array}{l}\text { - fraudulent activities on the real estate } \\
\text { market are minimized (forward contracts are } \\
\text { sold on a commodity exchange, which } \\
\text { beside providing control of agreements, } \\
\text { keeps records of the property rights for } \\
\text { forward contracts); }\end{array}$} \\
\hline $\begin{array}{l}\text { - paperwork is simplified (no need to issue } \\
\text { bonds, involve qualified and expensive } \\
\text { specialists both in the sphere of securities and } \\
\text { in the sphere of accounting and taxation); }\end{array}$ & \\
\hline $\begin{array}{l}\text { - the risk of changes is diminished by fixing } \\
\text { the price of the underlying asset expressed in } \\
\text { dollars, }\end{array}$ & $\begin{array}{l}\text { - helps to avoid related services and } \\
\text { additional costs (for notary services etc.) }\end{array}$ \\
\hline
\end{tabular}

It must be emphasized that currently no scheme of financing housing under construction exists in Ukraine which would protect investors 
completely. There are more risky and less risky variants. There are also variants which are more lucrative for developers, and those in which developers are compelled to adhere to due to various reasons.

\section{Diversification of investment resources forming tools in the context of increase of construction companies' activities}

Today, construction companies face a large number of factors containing their investment and construction activities (fig. 2). These factors, which are of economic, political and social origin, include legislative framework instability, excessive taxation, crime and corruption, lack of a well-designed system of measures to provide economic and legal protection of investors' interests; high inflation rates, which renders mid- and, even more so, longterm investments inefficient, population's low purchasing power, high custom fees, bureaucracy and incompetence of authorities, business partners' failure to pay, insufficient insurance guarantees provided by the state; underdeveloped infrastructure; limited range of services provided by local banks, shortage of staff; lack of production facilities etc.

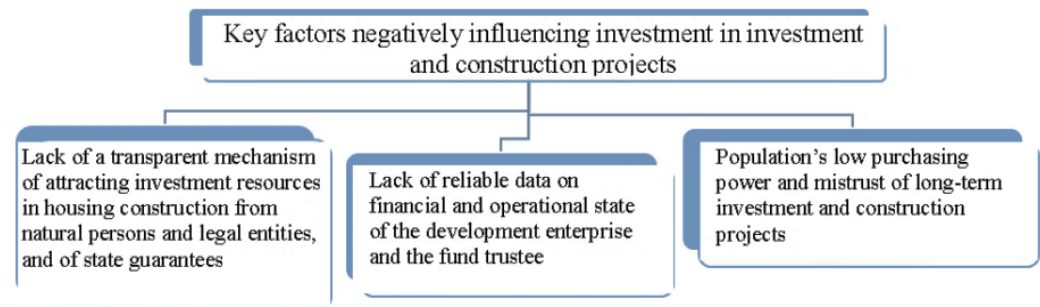

\section{Fig. 2. Key factors negatively influencing investment in investment and construction projects}

Investment risk value allows to demonstrate the probability of loss of investments and revenue therefrom. The following kinds of risks are distinguished: economic (trends in a region's economic development); financial (degree of balance of the regional budget and the enterprise's finances); political (distribution of political leaning among the population based on the results of the latest parliamentary and local elections); social (the level of social tension); ecological (the level of environmental pollution).

All these factors diminish investment attractiveness and has a negative impact on the investment activities of construction companies. When launching construction of residential property, developers are obliged to choose the mechanism of financing the project in line with their interests and the law. Before investing into a construction project, investors also must 
decide on the guarantees to protect their investments. The main point of coinvestment is pooling and accumulating the finances of small investors in a so-called "basket". These funds can be used for various purposes, in this case for real estate development. The use of co-investment institutes is a fairly common mechanism, whose advantages, besides the conformity of this investment method to Article 4 of the Law of Ukraine "On Investment Activities", include the legal mechanism of taxation optimization. In particular, funds (investment contributions) received by a corporate fund from an investor which is a natural person who wishes to participate in real estate development, are shared funds exempt from taxation according to the provisions of sub-item 141.6.1 of item 141.6, Article 141 of the Tax Code of Ukraine. This position was supported in the letter of the State Fiscal Service of Ukraine of 12.12.2017 №2938/6/99-99-15-02-02-15/IPK. However, the creation and functioning of such financing mechanism calls for significant expenditures, and thus is unavailable for many developers. The method of financing real estate construction through the system of co-investment institutes is unable to meet investors' needs in residential premises. In spite of the existence of legislative possibility to repurchase co-investment institute securities by means of the real estate acquired by it, it is recognized that the securities of a corporate investment fund (shares) can be repurchased only by paying for them with the company's money, which makes this option inexpedient and, as a result, leads to the lack of practice of repurchase of emitted investment certificates by an asset management company of a share fund through payment for these certificates by the real estate belonging to such company.

The construction investment mechanisms ignored by developers and investors alike also include the mechanism using the funds of PPFs (private pension funds). As of 31.12.2018, within the structure of invested pension assets the share of immovable property items with the index of UAH 17.7 million, or $0.04 \%$, holds only the fifth place in the structure of the investment portfolio of Ukraine. The deterrent, along with PPFs' passive investment strategy, is a complex system of PPF creation, which explains why the mechanism of investing into residential construction through PPF is the least accepted of all similar mechanisms.

Also, the mechanism of investing into residential construction through private pension funds cannot be considered an effective one. According to the legal definition of a pension payment, the latter is only provided in monetary form, therefore monetary fund investors into housing construction financing through private pension funds do not receive residential premises.

The system of housing construction investment through emission of interest-free (targeted) bonds (TB) is characterized by high risks and extra expenditures for developers (search for investors and security broker, 
issuance costs, floatation and redemption of bonds, risks of non-floatation of emitted securities etc.). Introduction of this mechanism is additionally complicated by the lack of proper statutory regulation of relations in the sphere of circulation redemption of targeted (housing) bonds.

The most common and popular housing construction investment mechanism in Ukraine is CFF. This scheme is strictly regulated by the Law of Ukraine "On Financial and Credit Mechanisms and Property Management during House Building and Real Estate Operations” of 19.06.2003 № 978-IV (further - the Law). The essence of the mechanism lies in the following:

- investor (potential housing owner) transfers property (funds) upon trust to a trustee in the aim of construction financing. This transfer is executed by a contract.

- The trustee enters into contractual relations with a developer who undertakes to construct an item of immovable property and hand a specific apartment into the trustee's ownership,

- the developer's surety bond before the trustee is mortgage;

- two contracts are concluded between the trustee and the developer:

1) transfer of property rights;

2) agency contract with suspension conditions.

According to the conditions of the above transactions, when the developer breaks the obligations it has undertaken, the trustee is endowed with a wide range of rights up to changing the developer.

At the same time, if a risk of developer's breach of its obligation exists, all property rights to the real estate are vested with the trustee based on the assignment agreement.

It is worth mentioning that, in spite of the general decrease of the number of companies holding a license for creating CFF, the total number of trustors and the amount of funds attracted via this mechanism grow steadily, which cannot be said about the mechanism of housing construction investment via RETF, although it can be put down to the peculiarities of each of the mechanisms. Thus, the first one is used by a real estate by investor for acquisition of ownership of an item, and the second one - for deriving profits form real estate transactions. Such type of investments is not common in our country, which explains the lack of developers' interest in this mechanism of investment.

As of 30.06.2019, as many as 52 financial companies had valid licenses for economic activities in the sphere of financial services provision, i.e. in property management for construction project financing and/or operations with real estate in accordance with the Law of Ukraine "On Financial and Credit Mechanisms and Property Management during House Building and Real Estate Operations". The total number of property trustors who concluded contracts with trustees on participation in construction financing 
funds (CFF) as of 30.06 .2019 is 28,156 persons, among which 27,968 are natural persons and 188 are legal entities ${ }^{2}$.

The analysis of the way of construction financing in the form of CFF provided for by the above-mentioned Law of Ukraine, leads to the conclusion that in the case of investment by creating a type B CFF, additional risks and significant costs are imposed on the trustee, which greatly discouraged the use of this legal mechanism. The dynamics of the change of the number of CFF trustors and their contributions is shown on Figure 3.

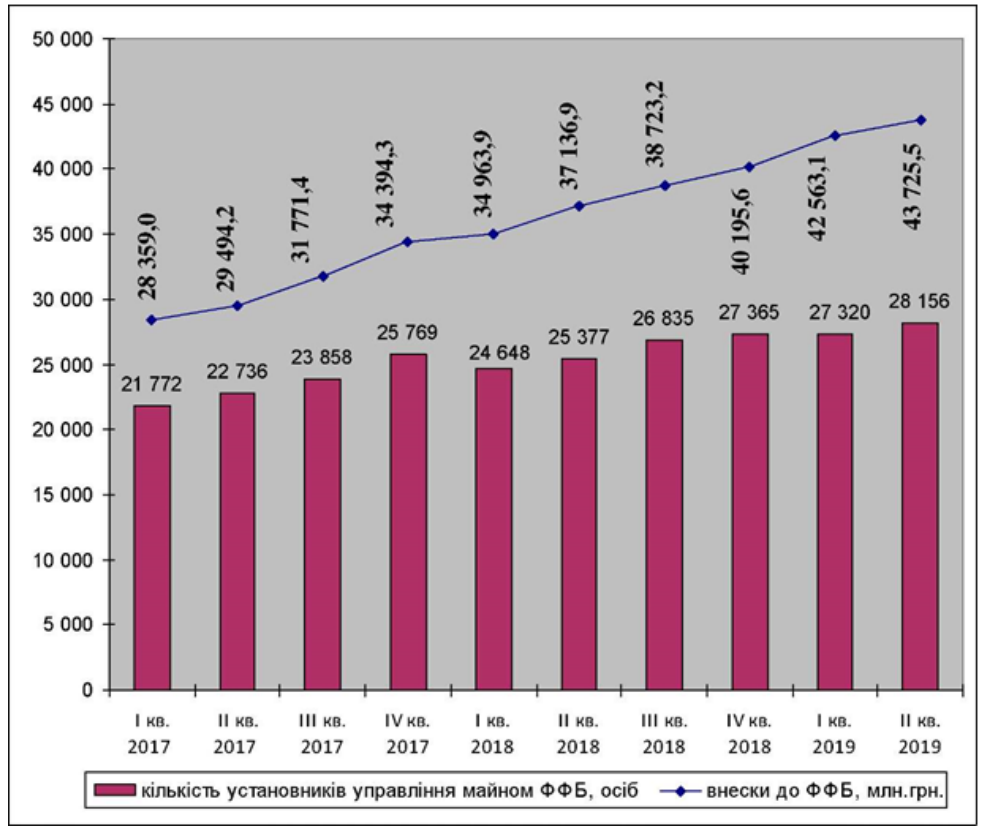

Fig. 3. Dynamics in the number of CFF trustors and attraction of funds from CFF trustors

In recent years, gradual rise of the number of CFF trustor and the flow of their contributions to CFF is observed. As compared with the similar period in 2018, as of 30.06 .2019 , the number of CFF trustors grew by $11.0 \%$ (2,779 persons). As of 30.06 .2019 , the amount of contributions made by CFF trustors reached UAH 43,725.5 million, which is $17.7 \%$ (UAH 6,588.6

\footnotetext{
${ }^{2}$ Official web-site of the National Committee on State Regulation in the Sphere of Markets of Financial Services https://www.nfp.gov.ua/files/OgliadRinkiv/FK/FK_I\%20kv
} 
million) more as compared with the same date in the previous year. Of these, the amount of contributions made by trustors - natural persons reached UAH $35,290.7$ million $(80.7 \%$ of the total amount of construction financing sources) as of 30.06.2019.

As of 30.06.2019, the amount of funds handed over to developers to construct facilities via the CFF mechanism reached UAH 25,530.4 million or $58.8 \%$ of the total amount of construction financing (table 2).

Table 2

Construction Financing with CFF

\begin{tabular}{|c|c|c|}
\hline Construction financing & As of 30.06.2019 & Ratio, \% \\
\hline On the fund's current account in a bank, million UAH & 374.2 & 0.9 \\
\hline On a deposit account in a bank, million UAH & $16,571.6$ & 38.2 \\
\hline $\begin{array}{c}\text { Handed over to developer to construct facilities, } \\
\text { million UAH }\end{array}$ & $25,530.4$ & 58.8 \\
\hline $\begin{array}{c}\text { Amounts written off for payments and cash management, } \\
\text { accrued interests on this account, million UAH }\end{array}$ & 42.5 & 0.1 \\
\hline Remuneration for trustee, million UAH & 882.2 & 2.0 \\
\hline Total amount of construction financing & $43,400.9$ & 100.0 \\
\hline
\end{tabular}

As of 30.06.2019, only one financial company holds a permit allowing to emit real estate transaction fund certificates (further - RETF certificates).

Table 3

Construction Financing with RETF

\begin{tabular}{|c|c|c|}
\hline Sources of construction financing & $\begin{array}{c}\text { As of } \\
\mathbf{3 0 . 0 6 . 2 0 1 9}\end{array}$ & Ratio, \% \\
\hline $\begin{array}{c}\text { Amount of contributions made by trustors } \\
\text { (natural persons), million UAH }\end{array}$ & $35,290.7$ & 80.7 \\
\hline $\begin{array}{c}\text { Amount of contributions made by trustors (legal entities), } \\
\text { million UAH }\end{array}$ & $8,434.8$ & 19.3 \\
\hline Trustee's own funds used to finance construction, million UAH & 17.7 & 0.04 \\
\hline $\begin{array}{c}\text { Total amount of sources of construction financing, } \\
\text { million UAH }\end{array}$ & $\mathbf{4 3 , 7 4 3 . 2}$ & $\mathbf{1 0 0 . 0}$ \\
\hline
\end{tabular}

The analysis of the ways of investing into housing construction provided for by the law (in the forms of co-investment institute, PPF, emission of noninterest-bearing (special purpose) bonds, CFF and RETF) testifies that, despite the availability of a number of such legal mechanism, the single genuinely functioning way of financing able to satisfy investors' needs in residential premises is investing money in housing construction in the form of type A CFF. Other investment modes either do not envisage the provision of residential property (private pension and corporate funds or RETF certificate emission) or are too complicated and inexpedient for developers (housing obligations emission) or trustees (type B CFF mechanism and the 
share fund system), which is why the practice of using these housing construction investment modes is virtually non-existent in Ukraine.

The system of housing construction financing via attraction of CFF (RETF) funds is aimed to ease the significant financial and legal tension in the housing segment of the market. However, the results of the conducted study helped reveal and systematize the problems of property management in the sphere of housing construction, which include lack of proper regulation of enabling properties of the "developer" and "customer" categories; lack of legal clarity as to the identification of the types of contracts concluded between the trustor and developer, especially as to the definition of indicators of targeted use of investors' funds; lack of regulation of identification of the risks which may divest a developer of its status; lack of clarity on the matters of procedures of provision and remuneration of auditor's services, which lowers the transparency of the CFF (RETF) system on the whole; restrictions as to the choice of banking institutions by the developer; absence of a defined algorithm of circulation of property rights in the system of CFF (RETF). The responsibility imposed by the Law on Property Management on CFF (RETF) trustees seems non-symmetric. As this Law does not have separate provisions on the trustees' liability, investors have to join general civil practice. Considering the complexity of the procedure of engaging a trustee in a direct property liability, there are grounds to verify that a CFF (RETF) trustee bears no real onus of property liability before trustors, placing in on the developer instead. However, under the Law on Property Management during House Building, a developer does not enter into contractual relationships with an investor. Thus, the investor is deprived of important leverage of influencing its contractor. Considering this, it would be rational to ensure a more equitable distribution of liability between the trustee and the developer, and putting the developer and investor on the same civil field via signing of bi- or trilateral agreements. The sphere of property management with the use of such securities as RETF certificates is characterized by extremely attractive tax incentives. Such situation is also common in international practice. However, in contrast to world traditions, the domestic system of RETF investment is not regulated as to other important parameters (the ratio of main income operations, the proportions of profit distribution). This creates potential risks of abuse in this investment area.

Under part 1 of Article 18 of the mentioned Law, the State guarantees the stability of environment for investment activities, enforcement of rights and legal interests of its subjects. At the same time, according to the data of the Kyiv city information and analytical system for urban development support "Kyiv Urban Development Cadaster", 67 unlawful development sites were 
found in Kyiv as of January $2018^{3}$. Depositing in financing of real estate is risky and is only justified if the construction has been finished. At the same time, much depends on the integrity of the developer or the asset management company (AMC). Many banks acted as administrators of construction financing funds (CFF), but because of the crash of a large number of banks (when many banks' licenses were revoked) these financing funds were left without administrators. Investors hare left with a single way to finish the construction - through enforced change of such AMC.

The system of housing construction financing via attraction of CFF (RETF) funds is aimed to ease the significant financial and legal tension in the housing segment of the market. However, the results of the conducted study helped reveal and systematize the problems of property management in the sphere of housing construction, which include lack of proper regulation of enabling properties of the "developer" and "customer" categories; lack of legal clarity as to the identification of the types of contracts concluded between the trustor and developer, especially as to the definition of indicators of targeted use of investors' funds; lack of regulation of identification of the risks which may divest a developer of its status; lack of clarity on the matters of procedures of provision and remuneration of auditor's services, which lowers the transparency of the CFF (RETF) system on the whole; restrictions as to the choice of banking institutions by the developer; absence of a defined algorithm of circulation of property rights in the system of CFF (RETF). The responsibility imposed by the Law on Property Management on CFF (RETF) trustees seems non-symmetric. As this Law does not have separate provisions on the trustees' liability, investors have to join general civil practice. Considering the complexity of the procedure of engaging a trustee in a direct property liability, there are grounds to verify that a CFF (RETF) trustee bears no real onus of property liability before trustors, placing in on the developer instead. However, under the Law on Property Management during House Building, a developer does not enter into contractual relationships with an investor. Thus, the investor is deprived of important leverage of influencing its contractor. Considering this, it would be rational to ensure a more equitable distribution of liability between the trustee and the developer, and putting the developer and investor on the same civil field via signing of bi- or trilateral agreements. The sphere of property management with the use of such securities as RETF certificates is characterized by extremely attractive tax incentives. Such situation is also common in international practice. However, in contrast to

\footnotetext{
${ }^{3}$ More illegal new construction sites in Kyiv (list). Electronic resource. Available at: https://www.unian.ua/economics/realestate/10172558-u-kiyevi-pobilshalo-nezakonnihnovobudov-spisok.
} 
world traditions, the domestic system of RETF investment is not regulated as to other important parameters (the ratio of main income operations, the proportions of profit distribution). This creates potential risks of abuse in this investment area. On the whole, the mechanism of legal regulation of the trustees' activities is rather rigorous. However, the lack of transparency in this sphere limits investors' control options and facilitates corruption. Thus, regulatory and information and analytical support of trust management of property in the housing construction system need further improvement to ensure a balance in the regulation of rights and obligations of trustors, trustees and developers.

Also, it would be expedient to spell out in the law the regulations concerning the change of an inefficient developer. The fact that no control is exerted over double and triple schemes of selling real estate constitute a huge problem. Here, much importance is placed on the developer's reputation. However, currently in Ukraine, a developer's investment portfolio is opened only after a building has been commissioned. It is in practice it can be aware of all future project designs at the stage when it has property rights and effects a sale. If after the sale, property rights for an apartment were entered into a property rights register, it would be impossible to sell this apartment for the second time. It would be expedient to complement Article 4 of the Law of Ukraine "On State Registration of Corporeal Rights to Real Estate and Their Encumbrances" (and other derivative regulations) by a provision on the state registration of property rights to accrual of ownership rights for real estate when investing in construction.

Escrow accounts could become an additional way to protect investors' rights. Internationally, escrow accounts are used along with such tools as collection of payments, letter of credit, debt security. What is an escrow account? It is a current account where the funds are frozen until an event defined by the contract takes place or obligations on account of which the funds were places are fulfilled. For example, if during an operation one party wishes to receive a confirmation that its partner has money at their disposal (or has to provide such proof itself), it opens an escrow account and credits the necessary sum to that account. A more concrete example can be real estate agreements: when a seller settles the agreement terms and conditions with the buyer, the buyer deposits money on an escrow account, which is open for a check by both buyer and seller at any time, but the money can be withdrawn from it only after all terms and conditions have been met and all documents have been signed. Being the escrow agent, the bank monitors the fulfilment of the agreement terms and conditions.

Recently, the National Bank of Ukraine (NBU) announced, that escrow accounts will be launched in Ukrainian banks, and the escrow agent has been 
defined. The regulatory body informs that this is connected with the changes in the legislation, and that the order of opening such accounts for banks has been developed. It is mentioned in the NBU Decision of 18.12.2017 № 133. This document regulates such issues as opening and closing of escrow accounts, defines the list of documents a client has to file to a bank to open such account, the list of operations available for such account, enables foreigners to open such accounts etc. However, today it refers to corporate management in joint stock companies. Moreover, the use of escrow accounts in some cases has become obligatory. Article 65 of the Law of Ukraine "On Joint Stock Companies" provided for a case of an obligatory use of escrow accounts when selling shares upon the demand of a person holding the controlling stake $(95 \%+$ of shares) (squeeze-out). Despite the fact that the concept of an escrow account was virtually absent from the legal system of Ukraine until March 2017, this mechanism was not new for Ukrainian lawyers. Considering that most of large Ukrainian M\&A agreements were concluded with foreign participation under foreign legislation, settlements were often conducted with the participation of foreign banks using escrow accounts. However, escrow accounts have not yet been adequately evaluated and used as a tool to diversify the formation of investment resources in the context of energization of domestic construction companies' activities.

\section{CONCLUSIONS}

Conceptual framework of information and analytical support of trust management of property in the system of housing construction have been developed by forming a comprehensive system of key indicators of the assessment of the activities of trust management schemes in housing development, which synthetizes an integral indicator of a developer's reliability and financial indicators of assessing construction financing funds' and real estate transaction funds' trustees, and accounts for a versatile characterization of existing schemes of investing into real estate on the primary housing market, which allows to create the conditions for equal, transparent and open process of investment implementation in housing construction. The implementation of the proposals made in this work on the improvement of investment mechanisms and control system will allow all investment process participants to balance the liability and reduce investment risks in the residential real estate construction. The methodology of the choice of mechanism enables the management of a construction company to make an optimal choice between the alternatives of investment support of a construction project. 


\section{SUMMARY}

The article provides a definition of structure and criteria of division and differentiation on systematization of investment resources formation sources taking into account specificity of functioning of contract building enterprises, methodological approaches to the analysis of use of financial resources for investment purposes, in their structure characteristic of features of financial maintenance of investment process of the enterprises of housing construction. The basic models of housing financing by the criterion of the mechanism of accumulation of savings and their transformation into investments are classified. This allowed to characterize the domestic model as a transitional bank-oriented one and on this basis to formulate recommendations on its further development prospects by using escrow accounts and introducing state registration of property rights for acquisition of ownership of real estate when investing in construction.

\section{REFERENCES}

1. Bushuiev S.D. Project management under the condition of "behavioral economics" [Text] / S.D. Bushuiev, D.A. Bushuiev, R.F. Iaroshenko // Complex Systems Development Management - 2018. № 33. - pp. 26-30.

2. Econometric tools for managing construction companies' financial security [Text] : [monograph] / [L.V. Sorokina et al.] ; under scientific supervision of professors Sorokina L.V. and Hoiko A.F. - Kyiv : Kyiv National University of Construction and Architecture, 2017. - 403 p.

3. Dotsenko-Belous N.A. Strategies of Construction Financing. - Kyiv: Law Firm "Vasil Kisil and Partners", 2009. - 500 p.

4. Theoretical and methodological framework of innovative and investment activities in Ukraine. / P.M. Kulikov, V.H. Fedorenko, H.M. Ryzhakova et al., collective monograph, LLC "DKS Center", Kyiv 2018. 442 p.

5. Tetyana Marchuk, Dmytro Ryzhakov, Galyna Ryzhakova and Sergiy Stetsenko (2017). Identification of the basic elements of the innovation and analytical platform for energy efficiency in project financing. Investment Management and Financial Innovations (open-access), 14(4), pp. 12-20. DOI: http://10.21511/imfi.14(4).2017.02

6. Pokolenko V.O. Introducing the tools for choosing the alternatives of construction project implementation by functional and technical integrity of implementing organizations / Pokolenko V.O., Ryzhakova G.M., Prykhodko D.O. // Complex Systems Development Management. - 2014. Issue 19. - pp. 104-108.

7. Ryzhakova G. M. Models of targeted choice of representative performance indicators of construction companies: diagnostic systems 
etymology and typology / G.M. Ryzhakova, D.O. Prykhodko, K.M. Predun // Complex Systems Development Management. - 2017. Issue 32. - p. 159-165.

8. Chernyshev D. Implementation of principles of biospheric compatibility in the practice of ecological construction in Ukraine [Text] / D. Chernyshev, I. Ivakhnenko, G. Ryzhakova, K. Predun // International Journal of Engineering \& Technology - UAE: Science Publishing Corporation, 2018- Vol 10, No 3.2: Special Issue 2 - pp. 584-586.

9. Chupryna Y. The identification of alternatives and changes in scenarios for the development of regional build clusters [Text] / Y. Chupryna, D. Ryzhakov, O. Malykhina // International Journal of Engineering \& Technology - UAE: Science Publishing Corporation, 2018 Vol 10, No 3.2: Special Issue 2 - pp. 484-486.

10. Fesun A.S. Improvement of the methodological tools of alternative mechanisms of construction program implementation: changing the management paradigm and innovative financing solutions [Text] / A.S. Fesun // Complex System Development Management. Collection of research papers. - Kyiv: Kyiv National University of Construction and Architecture, 2014. - Issue 19, Part 2 - pp. 122-128.

11. Zeltser, R.Ya., Bielienkova, O.Yu, Novak, Ye.V., Dubinin, D.V. Digital Transformation of Resource Logistics and Organizational and Structural Support of Construction [Text] / Zeltser, R.Ya., Bielienkova, O.Yu, Novak, Ye.V., Dubinin, D.V. // Science and Innovation, 2019 - Vol. 15(5) - pp. 38-51.

12. Izmailova K.V. The essence of economic cycles and their impact on the financial stability of construction [Text] / Izmailova K.V., Bielienkova O.Yu, Moholivets A.A. // Nauk. pr. NDFI, 2019 - Vol. 2 pp. 139-150.

13. Stetsenko S.. The hierarchical model of evaluation of infrastructure risks in construction / S. Stetsenko, T. Ilyina // Nauk. pr. NDFI, 2019. - Vol. 1. - pp. 119-129.

\section{Information about the author: Ryzhakova G. M.,}

Doctor of Economics, Professor, Head of the Construction Management Department Kyiv National University of Construction and Architecture 31, Povitroflotsky Ave., Kyiv, 03037, Ukraine 
NOTES 
NOTES 
Publishing house "Liha-Pres"

9 Kastelivka str., Lviv, 79012, Ukraine

44 Lubicka str., Toruń, 87-100, Poland

Printed by the publishing house "Liha-Pres"

Passed for printing: August 28, 2019.

A run of 150 copies. 